\title{
ANÁLISE DA MICRODUREZA SUPERFICIAL KNOOP E DA RESISTÊNCIA AO DESGASTE DE DENTES ARTIFICIAIS DE RESINA ACRÍLICA
}

KÁTIA RODRIGUES REIS

Dissertação apresentada à

Faculdade de Odontologia de

Bauru, da Universidade de São

Paulo, como parte dos requisitos para obtenção do título de Mestre em Reabilitação Oral.

Orientador: Prof. Dr. Gerson Bonfante (Edição Revisada)

BAURU 


\begin{tabular}{|c|}
\hline Reis, Kátia Rodrigues \\
Análise da microdureza superficial Knoop e da \\
resistência ao desgaste de dentes artificiais de \\
resina acrílica / Kátia Rodrigues Reis. - Bauru, 2005. \\
xix, 130 p. : il.; $30 \mathrm{~cm}$. \\
Dissertação (Mestrado) - Faculdade de \\
Odontologia de Bauru. USP. \\
Orientador: Prof. Dr. Gerson Bonfante
\end{tabular}

Autorizo exclusivamente para fins acadêmicos e científicos, a reprodução total ou parcial desta dissertação, por processos fotocopiadores e outros meios eletrônicos.

Assinatura do autor:

Data: 


\section{DADOS CURRICULARES}

\section{KÁTIA RODRIGUES REIS}

31 de Dezembro de 1977

1996 - 1999

$2000-2001$

$2003-2005$
Nascimento na cidade do Rio de Janeiro.

Curso de Odontologia na Faculdade de Odontologia da Universidade Federal do Rio de Janeiro (UFRJ).

Especialização em Prótese Dentária na Faculdade de Odontologia da Universidade do Grande Rio (Unigranrio).

Pós Graduação em Reabilitação Oral em nível de Mestrado na Faculdade de Odontologia de Bauru da Universidade de São Paulo (FOB-USP). 
"Do not follow where the path may lead...

Go instead where there is no path and leave a trail."

Robert Frost

DEDICATÓRIA 
a Deus,

Que, ao revelar o amor na sua essência e pureza, me conduziu à outra esfera da realidade e me permitiu compreender o verdadeiro significado da vida. Esse é o amor a que fomos destinados a buscar e desfrutar no mundo em que vivemos.

A ti dedico este trabalho!

AGRADECIMENTOS 
À minha mãe, Herminia, a maior incentivadora. Minha fonte de inspiração. Não existem palavras que expressem o significado de tudo o que você fez por mim. Obrigada por todo o apoio, suporte e zelo, essenciais para que eu pudesse realizar este sonho. Aliás, realizamos esse sonho juntas. O meu e o seu sonho. Para mim, você é a grande Mestra.

Ao meu pai, Aldaizo, e à minha irmã, Patrícia, por toda a compreensão, sendo fontes constantes de respeito incondicional às minhas decisões. Vocês me transmitiram a confiança e a segurança que eu precisava nesta fase da minha vida.

Aos meus familiares Sonja, Carlos, Simone, Ana, Sérgio, Aristides, Pedro, Mariana, Tiago e Vinícius por constituírem uma simbologia de família para mim. Obrigada pela presença, pelo interesse e pelo apoio durante toda a minha vida. Agradeço em especial ao meu eterno primo André, que nos foi levado tão precocemente. Dentre as muitas afinidades que tínhamos em comum, estava a paixão pela arte de lecionar. Havíamos iniciado uma família de mestres. Agora este papel cabe tão somente a mim e o cumprirei com todo o esmero.

Ao Prof. Dr. Gerson Bonfante, meu orientador, por ter transformado uma simples idéia em um belo trabalho. Obrigada pela paciência a cada passo, dando-me as diretrizes para que eu pudesse trilhar o caminho certo. O melhor caminho nem sempre foi o mais fácil, mas conseguimos, juntos, superá-lo. A sintonia entre a minha receptividade em aprender e a sua genialidade em idéias foram os grandes pilares para o 
desenvolvimento deste trabalho. A sua maneira única e enigmática de expressar pensamentos e sentimentos me ensinou muito mais que ciência, me ensinou vida.

A todos os amigos da minha adorada turma de Mestrado (Érico, Estevam, Filipe, Jonas, Lívia, Lucas, Mika, Paty, Rodrigo, Suedam e Thania,) por terem contribuído para a formação não apenas de uma equipe de trabalho, mas sim de uma verdadeira família. A presença de cada um foi fundamental para a criação de um clima de harmonia, cumplicidade e união durante todo o tempo em que convivemos. Isso transformou o nosso ambiente de trabalho em uma extensão dos nossos lares, onde recebíamos carinho, segurança e respaldo uns dos outros diariamente, fazendo com que as dificuldades parecessem mais amenas do que realmente eram. Vocês foram fontes constantes de alegria em minha vida e serão sempre especialíssimos em meu coração!!!

Agradeço especialmente à Lívia, a minha maior companheira. Obrigada por compartilhar a sua vida comigo e me permitir compartilhar a minha vida com você tão intensamente. A identidade entre nós revelada foi muito forte e simbolizou o início de uma grande e bela amizade.

Agradecimentos especiais também ao Jonas e à Paty, pela intimidade no compartilhamento de maravilhosos momentos e por serem fontes inesgotáveis de alegria e companheirismo. Todos esses momentos formaram fortes laços que levaremos sempre conosco. 
Ao Daniel, meu eterno mestre, pelo seu significado na minha vida. Obrigada por você existir desta forma transcendental pra mim. Agradeço pelo total apoio e incentivo, do início ao fim. Você simboliza a inspiração deste sonho.

Ao Prof. Dr. Luiz Fernando Pegoraro, pelos fascinantes pensamentos e ensinamentos transmitidos. Obrigada por ter me revelado a essência da verdadeira Odontologia.

Ao Prof. Dr. Paulo César Rodrigues Conti, pela orientação e incentivo sempre pertinentes na elaboração dos trabalhos, sendo um exemplo de docência.

Aos Profs. do Departamento de Prótese Dentária da FOB-USP, Dr. Accácio Lins do Valle, Dr. José Henrique Rubo, Dr. Paulo Martins Ferreira, Dr. Carlos dos Reis Pereira de Araújo, Dr. Vinicius Carvalho Porto, Dr. Wellington Cardoso Bonachela e Dr. Milton Carlos Gonçalves Salvador por todo o cuidado, incentivo e sabedoria na orientação do meu processo de aprendizado, sempre com muito bom humor e carinho.

À Faculdade de Odontologia de Bauru da Universidade de São Paulo, na pessoa de sua Diretora Profa. Dra. Maria Fidela de Lima Navarro, pela formação de uma comunidade cujo objetivo comum é a excelência.

Ao Departamento de Bioquímica da FOB-USP, representado pela Prof. Dra Marília Buzalaf, e ao Centro Integrado de Pesquisa da FOB-USP, representado pelo 
Prof. Dr. Ricardo Marins, pelo empréstimo dos equipamentos para a condução desse trabalho.

Ao Prof. Dr. José Roberto Pereira Lauris pela ajuda inestimável na realização da análise estatística desse trabalho.

Aos colegas de Pós graduação, Aline, Luciana, Renata, Amélio e Meliza pela amizade e companheirismo durante todo o curso.

Aos funcionários Reivanildo (Departamento de Prótese Dentária), Nelson (Departamento de Dentística), Benedito (Departamento de Dentística), Telma (Departamento de Bioquímica), Ovídio (Departamento de Bioquímica), Neusa (Centro Integrado de Pesquisa) e Tânia (Departamento de Histologia) que zelaram de forma extremamente atenciosa para a realização desse trabalho e asseguraram todo o suporte técnico necessário.

A todos que, ao longo destes dois anos em Bauru, fizeram parte do meu dia a dia, e com um sorriso ou um cumprimento, tornaram este tempo memorável. 


\section{SUMÁRIO}

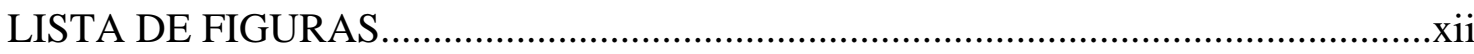

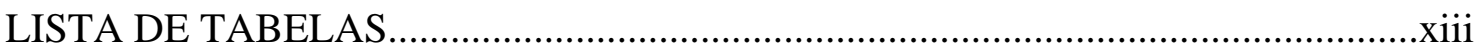

LISTA DE ABREVIATURAS E SÍMBOLOS...........................................................

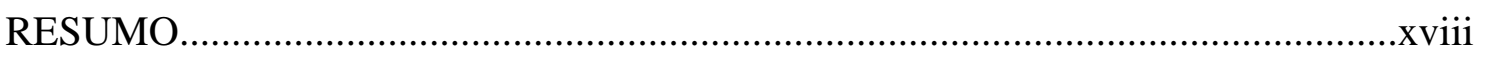

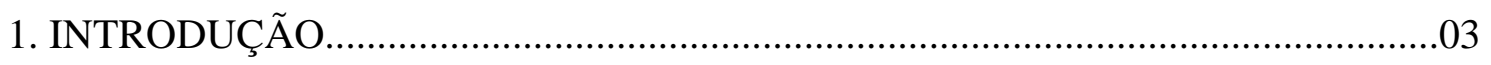

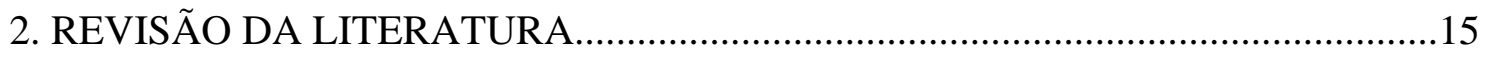

3. PROPOSIÇÃO

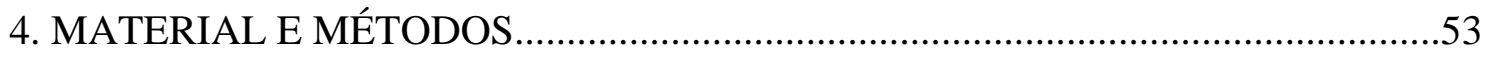

4.1. Mensuração da microdureza superficial Knoop..................................................54

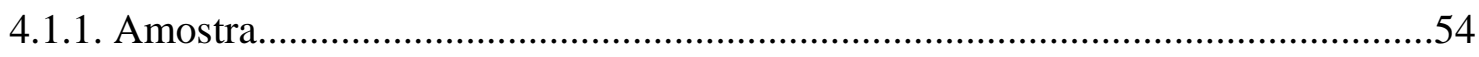

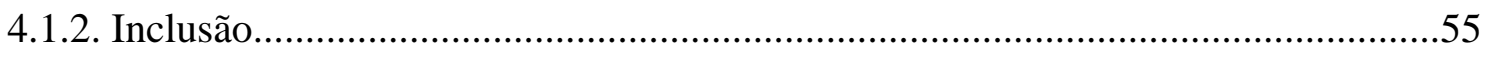

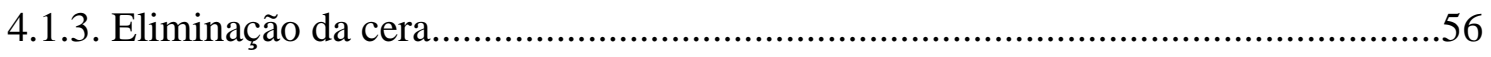

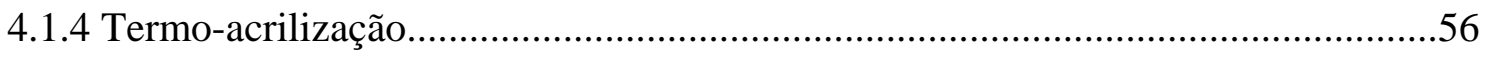

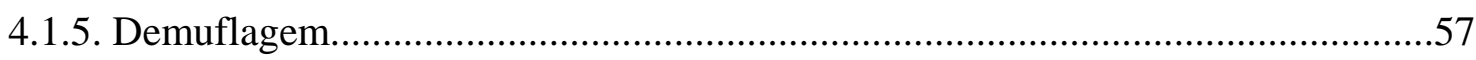

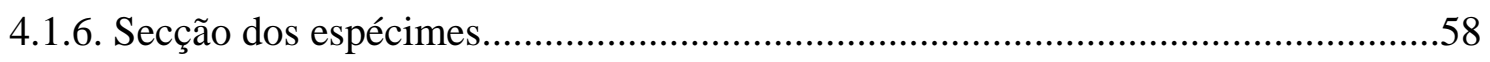

4.1.7. Planificação e polimento dos espécimes................................................................59

4.1.8. Análise da microdureza superficial dos espécimes..........................................60

4.2. Mensuração da resistência ao desgaste...............................................................65

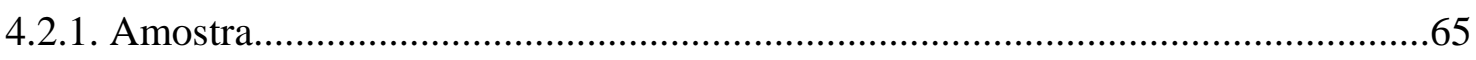

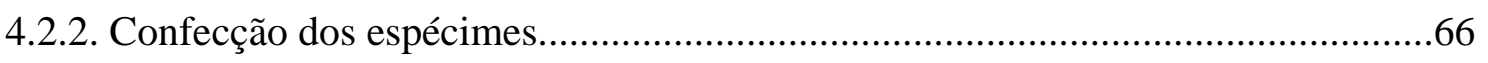

4.2.3. Determinação dos pontos de referência.................................................................66

4.2.4. Determinação do comprimento dentário inicial....................................................67

4.2.5. Confecção das placas metalo-cerâmicas antagonistas..........................................68 

4.2.6. Confecção das bases estabilizadoras de resina acrílica. .70

4.2.7. Adaptação da máquina de escovação simulada em máquina de

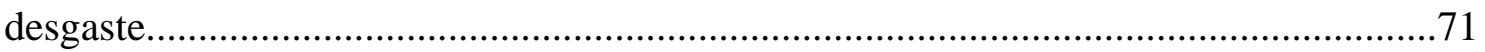

4.2.8. Determinação do comprimento dentário final....................................................73

5. RESULTADOS

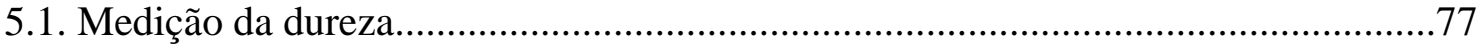

5.1.1. Comparação entre fases (antes e após a ciclagem de pH)..................................80

5.1.2. Comparação entre faces na mesma marca comercial...........................................81

5.1.3. Comparação entre marcas comerciais na mesma face..........................................82

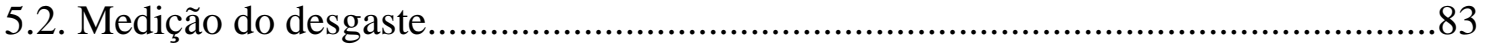

6. DISCUSSÃO

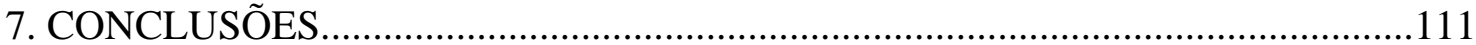

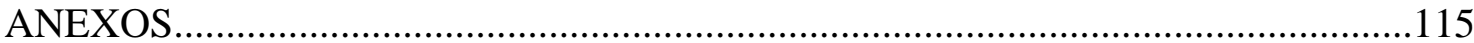

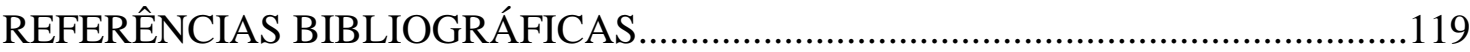

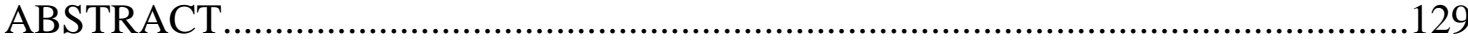





\section{LISTA DE FIGURAS}

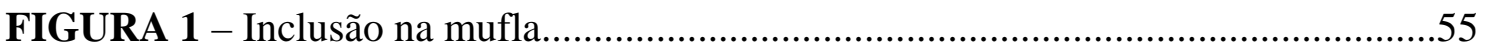

FIGURA 2 - Politriz Metalográfica Manual.............................................................58

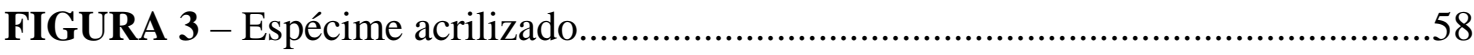

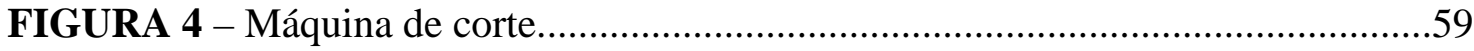

FIGURA 5 - Politriz com sistema de polimento múltiplo.........................................59

FIGURA 6 - Espécime do teste de dureza seccionado ao meio....................................59

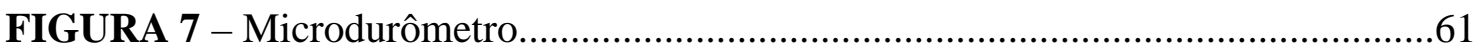

FIGURA 8 - Imagem de uma compressão em aumento de 10X................................62

FIGURA 9 - Espécime do teste de desgaste.............................................................66

FIGURA 10 - Microscópio Comparador..................................................................68

FIGURA 11 - Placa metalo-cerâmica antagonista.....................................................69

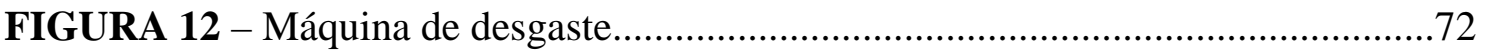

FIGURA 13 - Espécime na máquina de desgaste.....................................................72

FIGURA 14 - Média final dos valores de dureza (KHN) dos dentes artificiais antes e após a simulação do desafio ácido.........................................................78

FIGURA 15 - Média final geral dos valores de dureza (KHN) dos dentes artificiais antes e após a simulação do desafio ácido...... .80

FIGURA 16 - Média dos valores de desgaste (mm) dos dentes artificiais atritados contra a porcelana glazeada e jateada 


\section{LISTA DE TABELAS}

TABELA 1 - Média final dos valores de dureza (KHN) dos dentes artificiais antes e após a simulação do desafio ácido .78

TABELA 2 - Determinação das variáveis que apresentaram interação nas medições de microdureza (KHN) através da análise de variância (ANOVA) a três critérios .79

TABELA 3 - Comparação dos valores médios de microdureza Knoop (KHN) e desvio padrão nas diferentes faces (1, 2 e 3 ) considerando a mesma marca comercial. 81

TABELA 4 - Comparação dos valores médios de microdureza Knoop (KHN) e desvio padrão das faces e fases considerando as diferentes marcas comerciais .82

TABELA 5 - Valores médios (mm) das medições da altura dentária antes e após a realização do teste e o desgaste médio por marca comercial

TABELA 6 - Determinação das variáveis que apresentaram interação no ensaio de desgaste através da análise de variância (ANOVA) a três critérios.........84

TABELA 7 - Comparação dos valores médios de desgaste (mm) por face. 85

TABELA 8 - Comparação dos valores médios de desgaste (mm) entre marcas comerciais através do teste de Tukey 


\section{LISTA DE ABREVIATURAS E SÍMBOLOS}

$\%=$ por cento

$\geq=$ maior ou igual

$>=$ maior

$<=$ menor

C = constante aplicada na fórmula para o cálculo da dureza Knoop

c = carga usada no microdurômetro

d = comprimento da diagonal maior da penetração

$\mathrm{dP}=$ desvio padrão

$\mu \mathrm{m}=$ micrometro

${ }^{\circ} \mathrm{C}=$ graus centígrados

Kgf = quilograma-força

$\mathrm{cm}=$ centímetro

$g=$ gramas

KHN = número de dureza Knoop

$\mathrm{M}=$ molar

$\mathrm{mM}=$ milimolar

$\mathrm{ml}=$ mililitros

mm = milímetro

mm3 = milímetro cúbico

$\mathrm{kg}=$ quilograma

$\min =$ minuto

IPN = interpenetrating polymer network (rede polimérica interpenetrada)

$\mathrm{P}$ = nível de significância, probabilidade 
pH = potencial hidrogeniônico

rpm = rotações por minuto

$\mathrm{W}=$ watts

$\mathrm{Hz}=$ Hertz

$\mathrm{n}^{\mathrm{o}}=$ número

pvc $=$ polyvinyl chloride (cloreto de polivinil) 


\section{RESUMO}

Avaliou-se a dureza superficial Knoop de três marcas comerciais de dentes artificiais de resina acrílica convencional (Trubyte Biotone, Vipi Dent Plus e Ivostar) e quatro marcas de resina acrílica melhorada (Biotone IPN, Trilux, Biolux e Vivodent). Os espécimes ( $n=10)$ foram seccionados, planificados e mensurados em três níveis de profundidade antes e após a realização do desafio ácido. Para a avaliação da associação entre a dureza e o índice de desgaste, foram selecionadas três marcas comerciais com diferentes características: Biotone (resina acrílica convencional), Trilux (resina IPN) e Vivodent (resina com dupla ligação cruzada). A máquina de desgaste gerou a atrição dos espécimes $(n=10)$ contra a porcelana glazeada e jateada durante 100.000 ciclos à velocidade de 4,5 ciclos por minuto sob lubrificação à água. Os valores de desgaste foram determinados em milímetros utilizando-se o microscópio comparador. Os resultados de dureza e desgaste médios foram submetidos à análise de variância a três critérios (ANOVA) e teste de Tukey para comparações múltiplas. Os valores de dureza Knoop (KHN) variaram de 17,89 a 18,62 (antes) até 16,75 a 17,72 (após) nos dentes de resina acrílica convencional e entre 17,61 a 19,64 (antes) até 17,13 a 18,8 (após) nos de resina acrílica melhorada. O desafio ácido reduziu de maneira significativa a dureza superficial dos dentes artificiais $(\mathrm{p}<0,05)$. A dureza da superfície externa foi estatisticamente superior à interna em todas as marcas testadas, com exceção da marca Trilux $(\mathrm{p}<0,05)$. A diferença estatística dos resultados de dureza entre as diferentes marcas comerciais foi considerada provavelmente irrelevante do ponto de vista clínico $(\mathrm{p}<0,05)$. O desgaste no substrato glazeado foi de 0,14 mm (Trilux), 0,16 mm (Vivodent) e 0,17 mm (Biotone) e no substrato jateado de 0,64 mm (Vivodent), 0,66 
0,93 mm (Biotone). O teste de Tukey revelou que os valores de desgaste da marca comercial Biotone foram estatisticamente superiores aos valores das outras marcas no substrato jateado $(\mathrm{p}<0,05)$. Não houve diferença estatisticamente significante no desgaste entre as marcas de resina acrílica melhorada testadas. $(p<0,05)$. Não houve associação entre a dureza superficial e a resistência ao desgaste das marcas avaliadas no substrato jateado. 


\section{Introdução}

A cerâmica odontológica foi o primeiro material utilizado para a fabricação de dentes artificiais utilizados em próteses totais e parciais removíveis. Os dentes de porcelana apresentavam como principais vantagens: durabilidade HARRISON; HUGGETT $^{26}$, 1975, e SATOH et al. $^{50}$, 1992, dureza APPELBAUM ${ }^{10}$, 1984, e KAWANO et al. $^{30}$, 2002, resistência à ação de solventes orgânicos, estabilidade dimensional APPELBAUM ${ }^{10}, 1984$, estabilidade de cor APPELBAUM ${ }^{10}$, 1984, HIRANO et al. $^{27}$, 1998, e KAWANO et al. ${ }^{30}$, 2002, e resistência ao desgaste BODDICKER ${ }^{12}$, 1947, CRAIG; O’BRIEN; POWERS ${ }^{18}, 1988$, APPELBAUM $^{10}, 1984$, WHITMAN et al. ${ }^{60}$, 1987, HIRANO et al. ${ }^{27}, 1998$, ABE et al. ${ }^{2}, 2001$, e KAWANO et al. ${ }^{30}$, 2002. Apesar de todas essas vantagens, os dentes de porcelana não apresentavam união química à base da dentadura APPELBAUM ${ }^{10}$, 1984, CRAIG; O’BRIEN; POWERS $^{18}$, 1988, e WHITMAN et al. ${ }^{60}$, 1987, desgastavam o esmalte dentário APPELBAUM $^{10}, 1984$, WHITMAN et al. ${ }^{60}$, 1987, e ABE et al. ${ }^{2}, 2001^{2}$, apresentavam baixa resistência ao impacto APPELBAUM $^{10}$, 1984, e WHITMAN et al. ${ }^{60}$, 1987, fraturavam facilmente sob ação do estresse mastigatório BODDICKER ${ }^{12}$, 1947, CRAIG; O’BRIEN; POWERS, ${ }^{18}$ 1983, e HIRANO, et al. ${ }^{27}$, 1998, geravam sobrecarga oclusal ao osso alveolar subjacente, eram mais difíceis de serem caracterizados e não podiam ser desgastados ou polidos facilmente APPELBAUM ${ }^{10}$, 1984, e WHITMAN et al. ${ }^{60}$, 1987. Por fim, o contato dos dentes de porcelana criava freqüentemente um barulho audível e irritante APPELBAUM ${ }^{10}$, 1984, WHITMAN et al. ${ }^{60}$, 1987, e ABE et al. ${ }^{2}$, 2001, mais comumente encontrado em usuários de dentaduras mal adaptadas APPELBAUM ${ }^{10}, 1984$. 
Um novo campo de materiais para uso na fabricação dos dentes artificiais de porcelana surgiu com o advento dos dentes plásticos em 1940 CORNELL ${ }^{17}$, 1957. A matéria-prima básica utilizada na fabricação desses dentes foi a resina acrílica (polimetil-metacrilato), constituída na sua forma original pela união retilínea em cadeia de várias unidades de moléculas de metacrilato de metila ligadas intramolecularmente por uniões covalentes (CRAIG; O’BRIEN; POWERS ${ }^{18}$, 1988, PHILLIPS ${ }^{48}$, 1993, O’BRIEN $^{40}, 1997$, ANUSAVICE ${ }^{8,9}, 1998$, COMBE; BURKE; DOUGLAS $\left.{ }^{16}, 1999\right)$.

A principal vantagem dos dentes de resina acrílica era a presença de união química com a resina acrílica da base da prótese, eliminando a necessidade de retenções mecânicas (BEALL ${ }^{11}$, 1943, APPELBAUM ${ }^{10}$, 1984, CRAIG; O’BRIEN; POWERS ${ }^{18}$, 1988, WINKLER; MONASKY; KWOK ${ }^{61}$, 1992, HIRANO et al. ${ }^{27}, 1998$, e KAWANO et al. ${ }^{30}$, 2002). Dentre outras vantagens, foram citadas: alta resistência a rachaduras e ao ataque de solventes orgânicos APPELBAUM ${ }^{10}$, 1984, sensação mais natural ao contato dentário BEALL ${ }^{11}$, 1943, aparência mais natural BEALL ${ }^{11}$, 1943, e WINKLER; MONASKY; KWOK ${ }^{61}$, 1992, menor transmissão de trauma ao rebordo residual WHITMAN et al. ${ }^{60}$, 1987, e OGLE; DAVIS ${ }^{42}$, 1998, menor friabilidade BEALL ${ }^{11}$, 1943, e WINKLER; MONASKY; KWOK ${ }^{61}$, 1992, redução do ruído à oclusão WINKLER; MONASKY; KWOK ${ }^{61}$, 1992, facilidade na obtenção da montagem von FRAUNHOFER et al. ${ }^{57}, 1988$, SATOH et al. ${ }^{50}, 1992$, SATOH et al. ${ }^{49}, 1993$, e ADAMS et al. ${ }^{3}, 1996$ e na caracterização APPELBAUM ${ }^{10}$, 1984, maiores resistência ao impacto e flexural WINKLER; MONASKY; KWOK ${ }^{61}$, 1992, OGLE; DAVIS ${ }^{43}$, 1998, e KAWANO et al. ${ }^{30}$, 2002 e facilidade na realização do ajuste oclusal APPELBAUM ${ }^{10}$, 1984, WHITMAN et al. ${ }^{60}, 1987$, CRAIG; O’BRIEN; POWERS ${ }^{18}$, 1988, von 
FRAUNHOFER et al. ${ }^{57}, 1988$, SATOH et al. ${ }^{50}, 1992$, SATOH et al. ${ }^{49}, 1993$, ADAMS et al. $^{3}$, 1996, e KAWANO et al. $^{30}$, 2002, re-contorno APPELBAUM ${ }^{10}$, 1984, e WINKLER; MONASKY; KWOK ${ }^{61}$, 1992, e re-polimento APPELBAUM ${ }^{10}$, 1984, CRAIG; O’BRIEN; POWERS ${ }^{18}$, 1988, e SATOH et al. ${ }^{49}$, 1993. Por outro lado, os dentes de acrílico apresentavam como principal desvantagem a baixa resistência ao desgaste (BEALL ${ }^{11}, 1943$, BODDICKER $^{12}, 1947$, FRANKS $^{24}, 1962$, THOMSON $^{55}$, 1963, HARRISON; HUGGETT ${ }^{26}, 1975$, HARRISSON ${ }^{25}$, 1976, KHAN; MORRIS von FRAUNHOFER $^{32}$, 1984, APPELBAUM ${ }^{10}$, 1984, OGLE; DAVID; ORTMAN ${ }^{41}, 1985$, WHITMAN et al. $^{60}$, 1987, CRAIG; O’BRIEN; POWERS ${ }^{18}$, 1988, WINKLER; MONASKY; KWOK ${ }^{61}$, 1992, SATOH et al. ${ }^{49}$, 1993, HIRANO et al. ${ }^{27}$, 1998, e KAWANO et al. $^{30}$, 2002). Além disso, os dentes de acrílico não apresentavam estabilidade de cor, APPELBAUM $^{10}$, 1984, WHITMAN et al. ${ }^{60}$, 1987, e SATOH et al. ${ }^{49}$, 1993, sofriam a ação de corantes orgânicos, água, luz solar e agentes químicos APPELBAUM $^{10}$, 1984, e absorviam odores facilmente WHITMAN et al. ${ }^{60}, 1987$.

O método inicial de fabricação dos dentes plásticos consistiu na moldagem da resina acrílica sob alta temperatura e resultou em dentes de qualidade inferior aos obtidos posteriormente com o aperfeiçoamento das técnicas industriais e das propriedades da resina acrílica CORNELL ${ }^{17}$, 1957, e OGLE; DAVID; ORTMAN ${ }^{41}$, 1985. Os dentes pioneiros eram de má qualidade e apresentavam tendência à reversão parcial à sua forma de pó original quando utilizados em boca OGLE; DAVID; ORTMAN $^{41}$, 1985. Além disso, apresentavam baixa resistência a altas temperaturas e à presença de solventes e, portanto, sofriam degradação superficial, rachaduras e fácil desgaste quando comparados aos dentes naturais e de porcelana CORNELL ${ }^{17}, 1957$. 
O aperfeiçoamento da tecnologia de industrialização de dentes plásticos ocorreu com a introdução de máquinas de injeção para forçar o polímero fundido no interior de moldes. Porém, os dentes injetados apresentavam, ainda, tendência a rachaduras e sofriam alterações dimensionais na presença de água e solventes orgânicos OGLE; DAVID; ORTMAN ${ }^{41}, 1985$.

Um grande avanço na produção dos dentes plásticos ocorreu com o advento dos agentes de ligação cruzada da resina acrílica (“cross-linked”) na década de 50, o que solucionou o problema das rachaduras do material (OGLE; DAVID; ORTMAN ${ }^{41}$, 1985, WHITMAN et al. ${ }^{60}$, 1987, von FRAUNHOFER; RAZAVI; KHAN ${ }^{57}, 1988$, SATOH et al. ${ }^{50}$, 1992, e ADAMS et al. ${ }^{3}$, 1996). A adição de moléculas monoméricas bifuncionais com ligações duplas reativas em cada extremidade (dimetacrilato de etilenoglicol) permitiu o cruzamento entre as cadeias poliméricas lineares e a formação de ramificações (CRAIG; O’BRIEN; POWERS ${ }^{18}$, 1988, PHILLIPS ${ }^{48}, 1993$, O’BRIEN ${ }^{40}$, 1997, ANUSAVICE ${ }^{8,9}, 1998$, e COMBE; BURKE; DOUGLAS ${ }^{16}$, 1999).

Posteriormente, o aperfeiçoamento do processo de formação de ligação cruzada a partir da alteração do tipo e da quantidade de agentes de ligação OGLE; DAVID; ORTMAN $^{41}$, 1985, CRAIG; O’BRIEN; POWERS ${ }^{18}$, 1988, e ANUSAVICE ${ }^{8,9}$, 1998, e da combinação de variados polímeros e co-polímeros CORNELL ${ }^{17}$, 1957, e CRAIG; O’BRIEN; POWERS ${ }^{18}, 1988$, pelos diferentes fabricantes, resultou nos diversos dentes de resina acrílica convencional com propriedades físicas satisfatórias existentes 
atualmente no mercado (CRAIG; O’BRIEN; POWERS ${ }^{18}, 1988$, PHILLIPS ${ }^{48}$, 1993, O’BRIEN ${ }^{40}$, 1997, ANUSAVICE ${ }^{8,9}, 1998$, e COMBE; BURKE; DOUGLAS ${ }^{16}$, 1999).

A primeira modificação de impacto ocorrida nos dentes plásticos com ligações cruzadas foi o surgimento de resinas acrílicas com cadeias poliméricas interpenetradas, caracterizando um novo material: a resina acrílica IPN ("Interpenetrating Polymer Network”) (OGLE; DAVID; ORTMAN ${ }^{41}$, 1985, WHITMAN et al. ${ }^{60}$, 1987, e ABE et al. ${ }^{1}$, 1997). A indústria pioneira na divulgação desse conceito foi a Dentsply International, Inc., York, Pa. a partir do lançamento do dente artificial Trubyte Bioform IPN no mercado internacional no final dos anos 80. As cadeias poliméricas interpenetradas são estruturas formadas quando uma rede de polímeros é cruzada no interior de uma outra rede tridimensional ocupada por um segundo polímero cruzado. Assim, as redes cruzadas coexistem no mesmo volume do espaço (uma retida fisicamente dentro da outra) e não podem ser dissociadas sem que ocorra a ruptura das ligações químicas, o que resulta em propriedades físicas melhoradas para os materiais poliméricos (OGLE; DAVID; ORTMAN ${ }^{41}$, 1985, WHITMAN et al. ${ }^{60}$, 1987, e WINKLER; MONASKY; KWOK ${ }^{61}$, 1992).

Na mesma época, surgiu no mercado um outro material utilizado em dentes artificiais: a resina composta microparticulada (Isosit, Ivoclar Vivadent, Schaan, Liechtenstein). O fabricante descreveu esse material como um composto de partículas de carga de sílica vaporizada (de aproximadamente $70 \mathrm{~nm}$ de tamanho) fundidas ao sistema matricial da fórmula de Bowen. Esse sistema é o produto da reação de adição do Bisfenol A e glicidilmetacrilato (BIS-GMA) e constitui a matriz clássica da resina 
composta (WHITMAN et al. ${ }^{60}$, 1987, e ABE et al. $\left.{ }^{1}, 1997\right)$. A presença de partículas de carga inorgânica na estrutura polimérica dos dentes compósitos conduziu ao aumento da dureza superficial e, em contrapartida, reduziu a resistência ao impacto dos mesmos SUZUKI $^{54}, 2004$.

Em 2004, SUZUKI ${ }^{54}$ avaliou um novo dente compósito com carga inorgânica de tamanho nanométrico lançado recentemente no mercado odontológico. Esse dente apresentou características únicas em termos de homogeneidade devido à ampla dispersão das partículas nanométricas na matriz, embora o material não fosse altamente cruzado. Apesar da elevada dureza, foi sugerido que o dente nano-compósito apresentaria resistência ao desgaste limitada devido à presença do polimetil-metacrilato na matriz da resina. Apesar disso, o trabalho falhou em comprovar essa hipótese, pois não houve diferença estatisticamente significativa do desgaste entre os dentes nanocompósitos e aqueles constituídos de resina composta micro-particulada.

De acordo com SATOH et al. $^{49}, 1993$, os dentes plásticos de alta resistência foram desenvolvidos para solucionar principalmente o problema de desgaste dos dentes convencionais. Porém, a natureza altamente cruzada da resina acrílica moderna, reduziu significantemente a união dos dentes à base da dentadura, tornando imperioso o uso de retenções mecânicas. Outro método sugerido para aumentar a resistência à união seria a aplicação de um agente de ativação de superfície sobre os dentes previamente à inclusão. Ambos os procedimentos também podem ser realizados simultaneamente (APPELBAUM $^{10}$, 1984, e ANUSAVICE $\left.{ }^{9}, 1998\right)$. 
Apesar da evolução das propriedades físicas do polimetil-metacrilato, o desgaste desse material ainda ocorre com o uso clínico em boca (FRANKS ${ }^{24}$, 1962, THOMSON $^{55}$, 1963, e HARRISON; HUGGETT ${ }^{26}$, 1975).

De acordo com HIRANO et al. ${ }^{27}$, 1998, a resistência ao desgaste dos dentes artificiais é um dos requisitos mais importantes para a reabilitação de indivíduos edêntulos, pois permite a preservação do equilíbrio oclusal das próteses. Dependendo da extensão, o desgaste dentário pode gerar algumas implicações clínicas, tais como: aumento de forças horizontais e traumas teciduais associados $\mathrm{THOMSON}^{55}$, 1965, e OGLE; DAVIS ${ }^{42}, \quad 1998$, instabilidade da prótese THOMSON $^{55}, 1965$, comprometimento das relações maxilo-mandibulares ABE et al. ${ }^{1}$, 1997, OGLE; DAVIS $^{42}$, 1998, HIRANO et al. $^{27}, 1998$, e ABE et al. ${ }^{2}, 2001$, redução da eficiência mastigatória ABE et al. ${ }^{1}, 1997$, OGLE; DAVIS ${ }^{42}$, 1998, HIRANO et al. ${ }^{27}, 1998$, e ABE et al. ${ }^{2}$, 2001, e atividades para-funcionais ABE et al. ${ }^{1}$, 1997, e ABE et al. ${ }^{2}, 2001$.

Existem numerosas pesquisas sobre a resistência ao desgaste dos dentes artificiais comercialmente disponíveis (OGLE; DAVID; ORTMAN ${ }^{41}, \quad$ 1985, WHITMAN et al. ${ }^{60}$, 1987, von FRAUNHOFER; RAZAVI; KHAN ${ }^{57}$, 1988, e SATOH et al. $^{49}$, 1993). Entretanto, o freqüente surgimento de resinas com propriedades “melhoradas” utilizadas na fabricação dos dentes artificiais impõe a necessidade de mais estudos sobre o assunto.

Alguns testes laboratoriais realizados BODDIKER ${ }^{12}$, 1947, CORNELL et al. ${ }^{17}$, 1957, FRANKS ${ }^{24}, 1962$, HARRISON $^{25}$, 1976, OGLE; DAVID; ORTMAN ${ }^{41}$, 1985, von 
FRAUNHOFER; RAZAVI; KAHN ${ }^{57}$, 1988, DOUGLAS, DELONG; PINTADO ${ }^{20}$, 1993, e PAVARINA et al. $^{46}$, 2003, revelaram que os dentes de resina acrílica modificada apresentaram resistência ao desgaste superior aos dentes de resina acrílica convencional, embora outros trabalhos não tenham demonstrado diferença estatística entre os materiais avaliados (KAHN; MORRIS; von FRAUNHOFER ${ }^{32}$, 1984, KHAN; MORRIS; von FRAUNHOFER ${ }^{31}$, 1985, WHITMAN et al. ${ }^{60}$, 1987, von FRAUNHOFER; RAZAVI; $\mathrm{KAHN}^{57}$, 1988, SATOH et al. ${ }^{50}$, 1992, WINKLER; MONASKY; KWOK ${ }^{61}$, 1992, DOUGLAS; DELONG; PINTADO ${ }^{20}$, 1993, e OGLE, DAVIS $^{42}$, 1998). Diversos estudos baseados em modelos clínicos, também apresentaram resultados controversos sobre os dentes de resina acrílica melhorada (McDOWELL et al. ${ }^{35}$, 1988, ADAMS; JOOSTE; THOMAS 5 , 1989, ADAMS; JOOSTE; THOMAS ${ }^{4}$, 1991, e ADAMS et al. $\left.{ }^{3}, 1996\right)$.

Os equipamentos de teste disponíveis para a avaliação do desgaste de dentes artificiais foram usualmente desenvolvidos para uso industrial e os resultados obtidos são difíceis de serem reproduzidos e não são indicativos do desgaste intra-oral. Isso reflete a carência do estabelecimento de uma metodologia padronizada e reproduzível para o desenvolvimento de uma linha de pesquisa pertinente (WHITMAN et al. ${ }^{60}$, 1987). Assim, os diferentes desenhos experimentais e sistemas de medição que foram utilizados geraram dificuldades para a comparação dos resultados e permitiram como único meio plausível a listagem dos materiais testados em cada estudo (LINDQUIST; OGLE; DAVIS $\left.{ }^{34}, 1995\right)$. 
Existe, ainda, controvérsia no estudo dos materiais dentários inter-relacionando a dureza superficial e a resistência ao desgaste. Porém, estas propriedades não estão necessariamente inter-relacionadas. Portanto, o ideal seria que as pesquisas realizadas neste âmbito envolvessem ambas as propriedades mecânicas, na tentativa de obter resultados mais amplos sobre os materiais avaliados. Porém, poucas pesquisas seguiram este protocolo WHITMAN et al. ${ }^{60}$, 1987, e ABE et al. ${ }^{1}, 1997$, e avaliaram a dureza isoladamente baseando-se na medição após o acondicionamento em água destilada WHITMAN et al. ${ }^{60}$, 1987, ABE et al. ${ }^{1}, 1997$, KAWANO et al. ${ }^{30}$, 2002, e PAVARINA et al. $^{46}$, 2003, álcool WHITMAN et al. ${ }^{60}$, 1987, ou soluções desinfetantes PAVARINA et al. $^{46}$, 2003, sem levar em consideração a dinâmica do meio intra-oral, caracterizada por alterações cíclicas do pH na biofilme microbiano CARVALHO; CURY ${ }^{14}, 1999$. 


\section{Revisão de Literatura}

Em 1943, BEALL ${ }^{11}$ analisou o desgaste “in vivo" de dentes de resina acrílica através de medições em réplicas de próteses totais. Para isso, foram confeccionadas próteses totais duplas com dentes de resina para dois indivíduos, obtidos modelos através do vazamento de gesso no interior da prótese e obtida uma réplica da prótese sobre o modelo no início da avaliação. Durante a consulta de reavaliação, a prótese foi reposicionada sobre o modelo, a adaptação verificada e uma segunda réplica realizada. O desgaste foi determinado por medições realizadas nas réplicas entre um ponto de referência selecionado próximo à superfície dentária e o ponto mais alto de cada cúspide antes e depois do período de avaliação. O método de mensuração empregado apresentou acurácia de +/- 1,27 mm. Esse estudo indicou que o desgaste de dentes de resina ocorreu em um índice apreciável nos indivíduos avaliados. Como conclusão, o autor sugeriu que os dentes de resina acrílica são “experimentais” ao invés de permanentes e aconselhou a realização de estudos futuros sobre o desgaste de dentes de porcelana para a comparação de resultados e a seleção adequada do material a ser usado.

BODDICKER $^{12}$, em 1947, realizou um estudo laboratorial para avaliar o desgaste de dentes artificiais de próteses totais apresentando seis diferentes combinações de materiais: porcelana com porcelana; porcelana com liga de ouro tipo C; resina acrílica com resina acrílica; resina acrílica injetada com resina acrílica injetada; resina acrílica com liga de ouro tipo C e porcelana com resina acrílica. As próteses-teste foram confeccionadas em oclusão balanceada bilateral e montadas em um articulador conectado à máquina de desgaste, a qual movimentou o membro superior do articulador 
de um lado para o outro a 200 ciclos/min. Foram realizados três testes durante 12 horas, sendo o primeiro realizado por dez horas sob 2,7 kg de carga; o segundo por uma hora com pasta de pedra pomes sob 2,7 kg de carga e o terceiro por uma hora sob 11,4 Kg de carga sem nenhum agente abrasivo. A distância vertical entre os membros superior e inferior do articulador nas posições de relação cêntrica e de lateralidade direita e esquerda foi medida com o micrômetro de Boley no início e após cada teste. Os resultados mostraram que os dentes de resina acrílica desgastaram mais rapidamente que os dentes de porcelana ou de ouro em todos os testes. Os dentes de porcelana foram os que menos desgastaram em ambiente abrasivo, mas lascaram excessivamente nos outros dois testes.

O método utilizado no estudo de MYERSON ${ }^{37}$, em 1957, propiciou o desgaste de dentes artificiais em uma máquina de desgaste com agente abrasivo sob carga constante. O desgaste foi expresso em perda de volume. $\mathrm{O}$ estudo foi dividido em duas etapas: na primeira etapa, utilizou-se a pedra pomes como agente abrasivo e variou-se a carga de 1,8 até 18,2 kg. À medida que a carga foi aumentada, houve menor perda volumétrica nos dentes de porcelana X plástico que nos dentes plásticos X plásticos, sendo o índice médio da perda de volume desse grupo seis vezes maior que aquele. Na segunda etapa do experimento, a carga foi mantida constante $(5,5 \mathrm{~kg})$ e variou-se o tipo de abrasivo usado. Os resultados revelaram que o uso de abrasivos grosseiros tendeu a reduzir a diferença entre as duas combinações de materiais. Quando o carburundum foi usado como abrasivo, os dentes de plástico X plástico desgastaram 2,05 vezes mais que os dentes de porcelana X plástico. Com um abrasivo moderado de feldspato, a superioridade foi de 3,5/1,0. Com pó de talco, a superioridade foi de 7,2/1,0. 
Finalmente, em água corrente, a superioridade foi 11,6/1,0, ou seja, quando os dentes atritaram-se uns contra os outros sem nenhum abrasivo obteve-se o menor desgaste para os dentes de porcelana X plástico quando comparados aos dentes de plástico X plástico. Como conclusão, os resultados desse teste estão de acordo com a teoria de maior resistência ao desgaste dos dentes de porcelana X plástico sobre os dentes de plástico X plástico.

Uma nova metodologia para a realização de teste de desgaste de dentes artificiais foi desenvolvida por CORNELL et al. ${ }^{17}$, em 1957, a qual permitiu a análise de 12 pares de corpos-de-prova simultaneamente. Inicialmente os dentes (primeiros molares) foram encerados e processados com material para base de dentaduras (metilmetacrilato) através da técnica de termo-acrilização usual. Em seguida os dentes foram presos a bases de alumínio com godiva de baixa fusão e cada conjunto foi pesado após secagem em forno a vácuo antes e depois do teste. O conjunto dente (superior)/base foi preso ao braço móvel da máquina de teste e o conjunto dente (inferior)/base à parte fixa da máquina, de modo que os dentes articulavam-se precisamente uns contra os outros. A força do braço móvel foi de 0,454 kg a 90 ciclos/min com o objetivo de simular o ciclo mastigatório. Foram realizados quatro testes de desgaste com 18.500 ciclos de quatro horas de duração para cada grupo, com dentes plásticos experimentais desgastados contra dentes plásticos padrão em ambientes seco, molhado e na presença de alimentos. Os resultados do teste revelaram que os dentes padrão constituídos de ligações cruzadas apresentaram desgaste superior ao dente com ligações cruzadas experimental. Esses dados correlacionam-se com os dados clínicos usualmente encontrados, particularmente aqueles obtidos em ambiente úmido ou com pastas de alimentos. A validação da 
metodologia empregada foi determinada estatisticamente em termos de reprodução, acurácia, erros sistemáticos e desvio estatístico.

FRANKS $^{24}$, em 1962, realizou uma avaliação clínica do desgaste de dentes de acrílico em 140 usuários de próteses totais duplas instaladas cinco anos antes da avaliação. O autor utilizou um sistema de classificação visual para o desgaste ocorrido na superfície oclusal dos dentes, classificando-o como: (1) Ligeiro - nenhuma alteração perceptível na forma da cúspide. (2) Moderado - forma da cúspide modificada. (3) Severo - alteração completa da forma da cúspide. O desgaste foi correlacionado com as seguintes variáveis coletadas no estudo: contato dos dentes posteriores em relação cêntrica (presente ou ausente); movimento mastigatório (dobradiça ou ruminante); fatores traumáticos aos tecidos de suporte (articulação livre ou travada; retenção satisfatória ou insatisfatória e estabilidade satisfatória ou insatisfatória); período de uso das próteses (apenas durante o dia ou durante o dia e à noite) e fratura das próteses ocorrida em boca. As conclusões do estudo foram: 1) O desgaste dos dentes posteriores levou a perda de oclusão em relação cêntrica e resultou em protrusão mandibular na tentativa de atingir a oclusão cêntrica (posição de máximo contato dentário); 2) Houve correlação positiva entre o grau de satisfação das próteses e o desgaste encontrado nas superfícies oclusais dos dentes; 3) Não houve correlação significante entre o desgaste dentário e o período de uso das próteses, o que sugeriu que o desgaste ocorreu devido à abrasão de alimentos e não ao contato dentário; 4) Houve correlação significante entre a articulação livre e o grau de desgaste dos dentes; 5) Houve relação entre a incidência de fratura das próteses e a quantidade de desgaste presente. 
Com o intuito de fornecer indícios da carga requerida para gerar desgaste dentário em próteses totais, THOMSON ${ }^{55}$, realizou em 1965 um teste laboratorial de resistência ao desgaste de dentes de acrílico. Para isso, dentes posteriores em oclusão foram fixados a um equipamento que apresentava uma plataforma inferior móvel no plano horizontal. O comprimento inicial dos dentes foi registrado e a medição dos dentes repetida a cada 12 ou 24 horas. Houve uma redução do desgaste dentário à medida que a área oclusal em contato aumentou no decorrer dos ensaios (entre 2,3 e 4,5 kg). Dessa forma, quando os dentes atingiram desgaste acentuado, foi observado apenas um ligeiro desgaste até mesmo na presença de cargas excessivas (9,1 kg). Assim, o autor sugeriu que o uso de dentes artificiais com áreas de contato planas incorporadas ao desenho de suas superfícies oclusais poderia ser vantajoso para o controle do desgaste dentário.

Apesar de vários estudos salientarem a relativa resistência ao desgaste entre a combinação de dentes artificiais de porcelana e de resina acrílica, ainda existem teorias conflitantes sobre o assunto. Baseado nisso, KORAN; CRAIG; TILLITSON ${ }^{33}$, em 1972, propuseram a realização de um estudo para determinar o coeficiente de fricção dos materiais utilizados na fabricação de dentes artificiais. O estudo foi realizado a partir da atrição de corpos de prova hemi-esféricos de resina acrílica e porcelana contra lâminas constituídas dos mesmos materiais (3,81 X 10,16 cm) em uma máquina de teste sob cargas e velocidades variáveis. As seguintes combinações foram testadas em ambientes seco e molhado (através do uso de saliva fresca): 1) hemi-esfera de resina acrílica com lâmina de resina acrílica; 2) hemi-esfera de resina acrílica com lâmina de porcelana; 3) hemi-esfera de porcelana com lâmina de resina acrílica e 4) hemi-esfera 
de porcelana com lâmina de porcelana. Os autores concluíram que: 1) As variáveis de carga e velocidade não tiveram efeito significativo sobre os coeficientes de fricção dos materiais, excetuando-se a porcelana deslizando sobre porcelana em ambiente molhado; (2) O coeficiente de friç̧ão foi maior em ambiente molhado comparado com o ambiente seco para todos os materiais, excetuando-se a porcelana deslizando sobre a resina acrílica, quando não foi observada diferença significativa; (3) Em ambiente molhado a resina acrílica deslizando sobre a porcelana e a porcelana sobre a resina acrílica tiveram os menores coeficientes de fricção; (4) Em ambiente molhado, a resina acrílica deslizando sobre a resina acrílica apresentou coeficiente de fricção menor que a porcelana deslizando sobre a porcelana.

OHASHI et al. $^{44}$, em 1973, realizaram um estudo laboratorial para avaliar o desgaste ocorrido na superfície oclusal de dentes artificiais de próteses totais em uma situação que, segundo os autores, aproximava-se das condições clínicas. O objetivo do trabalho foi induzir os dentes artificiais de próteses totais ao desgaste através do uso de um articulador modificado. Essa máquina produziu 25 ciclos por minuto sob 500 g de carga durante seis horas por dia e levou em média uma semana para desgastar 0,5 mm do corpo-de-prova. Foram realizados dois testes de desgaste de 0,5 mm cada, sendo o número de ciclos necessários para atingir tal desgaste precisamente registrado no momento em que a haste guia do articulador se erguia a uma altura de 0,5 mm estabelecida pela oclusão cêntrica dos dentes artificiais. Foram avaliadas três marcas comerciais de dentes de porcelana (Shofu Ace, G-C Homolooks e Fujika) e uma de dentes de resina acrílica (Shofu). Os autores utilizaram 16 combinações desses dentes artificiais montados nas regiões superior e inferior do articulador. Foram obtidas as 
seguintes conclusões: 1) A prótese total com dentes de porcelana no arco superior e dentes de resina no arco inferior apresentou o mais alto grau de resistência ao desgaste; 2) Quando essa ordem foi invertida, essa combinação apresentou ainda o segundo maior grau de resistência ao desgaste; 3) A prótese total com dentes de porcelana em ambos os arcos foi a terceira em resistência ao desgaste; 4) O uso de dentes de resina em ambos os arcos foi a combinação mais susceptível ao desgaste; 5) Os dentes que apresentaram anatomia cuspídea pontiaguda foram os que mais facilmente se desgastaram.

HARRISON; HUGGETT ${ }^{26}$, em 1975, desenvolveram um dispositivo para medir o desgaste de dentes artificiais ocorrido em boca. O instrumento de medição permitiu o preciso reposicionamento de dentaduras em sua base e viabilizou a medição de pontos de referência idênticos. O dispositivo era constituído de uma base de metal, uma haste vertical e um braço horizontal com o aferidor (com capacidade de medição de até 0,02 mm). Para garantir que cada dentadura fosse posicionada no instrumento de medição aproximadamente na mesma posição a cada período de avaliação, utilizou-se um guia de montagem. Como pontos de referência para as medições, foram utilizadas bolas de aço inoxidável posicionadas com resina acrílica de polimerização rápida na face distal dos segundos molares das dentaduras superior e inferior. As medições foram feitas entre os pontos de referência e vários outros pontos das superfícies oclusais dos dentes posteriores e das bordas incisais dos dentes anteriores. As medições subseqüentes foram feitas utilizando-se os modelos de gesso originais para o reposicionamento da dentadura. A análise estatística revelou um desvio padrão de +/- 0,07 mm para as medições quando foi realizada a remoção do modelo e da prótese do aparelho ou somente da prótese do modelo. As medições puderam ser feitas com desvio padrão de 
+/- 0,03 mm em um ponto próximo ao ponto de referência (segundo molar) ou com desvio padrão de +/- 0,07 mm em um ponto distante ao ponto de referência (primeiro pré-molar). Os autores concluíram que as próteses puderam ser removidas e reposicionadas no aparelho de medição de desgaste de dentes artificiais com alto grau de eficácia.

No ano seguinte, HARRISON ${ }^{25}$ realizou um estudo clínico do desgaste de dentes artificiais de próteses totais utilizando o instrumento de medição descrito anteriormente. A amostra foi composta por nove indivíduos apresentando próteses totais duplas com dentes de resina acrílica, quatro indivíduos com próteses totais duplas com dentes de porcelana e quatro indivíduos com uma prótese com dentes de resina acrílica e a prótese oponente com dentes de porcelana. As próteses foram mensuradas no início da pesquisa e posteriormente em intervalos de seis meses durante aproximadamente dois anos. No grupo constituído pelas próteses com dentes de resina acrílica, os resultados revelaram que, apesar de ter ocorrido uma grande variação entre os indivíduos, o padrão de desgaste das próteses superior e inferior foi bastante semelhante para os mesmos indivíduos, excetuando-se um que admitiu não usar a prótese inferior regularmente. $\mathrm{O}$ grupo constituído de próteses com dentes de porcelana apresentou desgaste consideravelmente menor que o grupo de dentes de resina acrílica, e o desgaste interindivíduos foi semelhante. Já no grupo de próteses constituídas de dentes de porcelana opostos a dentes de resina acrílica, houve uma diferença marcante no desgaste entre os dois materiais, sendo que o índice de desgaste dos dentes de porcelana foi baixo (tal como no grupo constituído somente de dentes de porcelana), ao passo que os dentes de resina acrilica apresentaram um alto índice de desgaste (maior que o desgaste ocorrido 
nos dentes de resina acrílica de próteses constituídas apenas desse material). O estudo confirmou a impressão clínica de que dentes de resina acrílica desgastam mais rapidamente que dentes de porcelana, mas não a de que dentes de resina acrílica opostos a dentes de porcelana desgastam-se menos que dentes de resina acrílica opostos um ao outro.

Em 1984, APPELBAUM ${ }^{10}$ realizou uma revisão sobre as teorias de seleção de dentes artificiais posteriores de porcelana e de resina acrílica. O autor sugeriu algumas regras básicas para a combinação desses materiais: 1) Os dentes de acrílico posteriores não devem ser colocados em próteses com dentes de porcelana na região anterior, pois o acrílico se desgastará mais rapidamente que a porcelana, gerando contatos anteriores prematuros e resultando em trauma desnecessário na região anterior da maxila; 2) Os dentes de porcelana ântero-superiores não devem ser opostos à dentição natural inferior. Isso ocorre porque à medida que a dentadura superior se assenta e ocorre o desgaste funcional dos dentes posteriores, a mandíbula se moverá para cima e para frente, gerando o contato na região anterior e resultando no desgaste do esmalte dos dentes ântero-inferiores; 3) A oposição de dentes anteriores de porcelana contra porcelana é usualmente contra-indicada em relações maxilo-mandibulares classe I e classe II. Isso se deve ao movimento para cima e para frente da mandíbula com o assentamento das próteses; 4) Pacientes com queixa de barulho nas próteses atuais não devem receber novas próteses com dentes de porcelana. Concluindo, o autor afirmou que nem a porcelana e nem o acrílico são os materiais ideais para a fabricação dos dentes artificiais posteriores, devendo o profissional estar atento às condições orais e peri-orais para estabelecer qual material é mais adequado para cada paciente. 
KHAN; MORRIS; von FRAUNHOFER ${ }^{32}$, em 1984, realizaram um estudo para avaliar as características de desgaste de três marcas comerciais de dentes artificiais de resina acrílica não-anatômicos (Dentsply International.; Myerson Tooth Corp.; e Universal, Lactona Corp.). Os espécimes foram constituídos de quatro dentes artificiais posteriores imersos em gesso e mediu-se a altura da superfície oclusal de cada dente localizada acima da superfície do gesso com um paquímetro com acurácia de 0,01 cm. Posteriormente, cada corpo-de-prova foi montado na máquina de desgaste e submetido a 500 ciclos contra lixa de silicone carbide de granulação 600. Então, novas medições das alturas oclusais foram realizadas e os corpos de prova submetidos a mais 500 ciclos de desgaste e por fim a perda da altura oclusal foi novamente mensurada. Houve diferença significativa no desgaste dos dentes de resina acrílica não anatômicos produzidos por diferentes fabricantes. Os dentes Dentsply apresentaram maior desgaste que os dentes Myerson e Universal a 500 ciclos e maior desgaste que os dentes Myerson a 1000 ciclos. Não houve diferença significante entre os dentes Universal e Myerson. O aumento do desgaste dos dentes Myerson e Universal entre 500 e 1000 ciclos comparado com os dentes Dentsply sugere que após longos períodos de uso, o índice de desgaste das três marcas comerciais se tornaria semelhante.

No ano seguinte, KHAN; MORRIS; von FRAUNHOFER ${ }^{31}$ realizaram outro estudo para avaliar se a presença de cúspides nos dentes artificiais anatômicos produzidos por diferentes fabricantes interfere no grau de desgaste dos mesmos. A técnica experimental utilizada nesse trabalho foi a mesma usada anteriormente, sendo o desgaste dentário expresso como a perda percentual de peso da superfície oclusal discriminada para cada cúspide de cada dente. Os valores citados para cada fabricante foram os valores médios obtidos com todas as cúspides dos quatro dentes dentro de cada 
corpo-de-prova. Houve diferença significante no desgaste das cúspides dos dentes de diferentes fabricantes, embora as diferenças tenham sido pequenas. Os dentes Myerson desgastaram ligeiramente mais que os dentes Dentsply e Universal. Dessa forma, os autores concluíram que a seleção dos dentes artificiais pode ser baseada muito mais nas preferências pessoais e considerações estéticas que em diferenças relevantes no padrão de desgaste.

Em 1985, OGLE; ORTMAN ${ }^{43}$ elaboraram uma metodologia para medir precisamente o desgaste “in vivo” de dentes artificiais de próteses totais. A nova técnica de mensuração foi denominada estereofotometria e permitiu a medição do desgaste a partir da análise de dados geométricos como tamanho, forma e posição de objetos em fotografias. A estereofotografia permite a criação de um modelo óptico ou espacial que pode ser precisamente medido. O princípio da criação do modelo estereoscópico é a visão binocular, segundo a qual os dois olhos enviam imagens ligeiramente diferentes de um mesmo objeto para o cérebro e essas imagens são interpretadas em termos de profundidade, comprimento e largura. De modo similar, se duas estereofotografias de um objeto são justapostas de modo que o olho esquerdo enxergue a fotografia esquerda e o olho direito a fotografia direita, a percepção de profundidade pode ser tão clara como se o objeto fosse visto diretamente. Nesse trabalho, as estereofotografias foram obtidas através do uso de duas câmeras fotográficas, um conjunto de lentes de aproximação para perto e um suporte para as câmeras. Posteriormente, a redução das estereofotografias foi obtida através da projeção dupla para permitir a visualização e a mensuração do modelo óptico. A confiabilidade do método foi determinada pelo coeficiente de correlação de Pearson a partir de dados obtidos por três examinadores 
que mensuraram uma prótese-teste anualmente ao longo de três anos. A confiança interexaminadores foi igual ou superior a 0,9998, o que significou que os examinadores obtiveram resultados aproximadamente idênticos em seus registros e concordaram dentro de uma variação de +/- 0,01 mm. Além disso, não houve diferença significante na comparação entre a média final e o registro real anual, o que sugeriu adequada calibração da aparelhagem. Dessa forma, os autores descreveram um método altamente preciso para a mensuração do desgaste in vivo de dentes artificiais de próteses totais.

OGLE; DAVID; ORTMAN ${ }^{41}$, em 1985 realizaram uma avaliação clínica do desgaste de um novo material utilizado na produção de dentes artificiais (Trubyte Bioform IPN). O desgaste foi determinado pela mensuração das alterações topográficas das superfícies dentárias comparadas por estereofotografia inicialmente e após seis, 12, 24 e 36 meses. Os dentes artificiais foram posicionados em hemi-arcos diametralmente opostos de modo que o grupo experimental (Trubyte Bioform IPN) apresentou-se sempre oposto ao grupo controle (Biotone). Os indivíduos ativos foram divididos em três grupos: O grupo 1 (dentes não-anatômicos) apresentou 16 arcos com dentes experimental e controle; o grupo 2 (dentes anatômicos) apresentou 16 arcos com dentes experimental e controle e o grupo 3 (próteses totais superiores) apresentou oito arcos com dentes experimental e controle. Os resultados revelaram haver diferença significante entre a média de desgaste do grupo experimental e controle dos pontos de contato. O grupo experimental desgastou 32,7\% menos aos seis meses, 31,8\% menos aos 12 meses, 34,7\% menos aos 24 meses e 27,6\% menos aos 36 meses que o grupo controle. Não houve diferença estatisticamente significante entre os grupos para os pontos de não contato. O grupo experimental e o grupo controle desgastaram 
aproximadamente a mesma quantidade quando opostos a dentes naturais ou artificiais. Houve pequena diferença na quantidade de desgaste entre os dentes artificiais anatômicos e não anatômicos. A quantidade média total de desgaste para os grupos controle e experimental após 36 meses foi de 0,25 e 0,18 mm, respectivamente. O novo material revelou-se como uma alternativa no tratamento de pacientes para reduzir o desgaste de dentes artificiais de resina acrílica.

WHITMAN et al. $^{60}$, em 1987, compararam a resistência ao desgaste e a microdureza superficial de dentes de resina acrílica (Trubyte/Bioform, Dentsply), resina acrílica IPN (Trubyte/Bioform IPN, Dentsply) e resina composta microparticulada (Isosit, Ivoclar). Para isso, foi desenvolvido um aparelho de desgaste baseado no sistema "pino-disco". Os fabricantes forneceram espécimes dos materiais em formato de discos de 18 mm de diâmetro e 2,5 mm de espessura. Os espécimes de cada fabricante foram divididos em dois grupos de acordo com o pré-condicionamento por uma semana a $37^{\circ} \mathrm{C}$ em: água destilada (“controle”) ou etanol a 75\% (solvente químico recomendado para uso como simulador da ação de alimentos). O desgaste foi realizado por um pino de aço inoxidável de dois milímetros de diâmetro sob 10 MPa de carga à velocidade de 27 ciclos/min. A leitura da profundidade da trajetória de desgaste foi obtida por uma sonda ligada a um transformador que mediu o desgaste a cada 30 horas em 10 pontos espaçados ao redor da trajetória. Os resultados indicaram que a resina acrílica IPN e o Isosit mostraram-se igualmente resistentes ao desgaste em água e etanol a 75\%, ao passo que a resina acrílica convencional foi mais susceptível ao desgaste na presença da solução de etanol, sugerindo que os dentes artificiais confeccionados com esses novos materiais foram mais resistentes ao desgaste em condições intra-orais que os dentes 
artificiais feitos de resina acrílica convencional. No teste de dureza, os materiais armazenados em água apresentaram índice de dureza de aproximadamente um, o que significa que os valores de dureza inicial e final foram praticamente iguais, ou seja, não houve amolecimento do material. Inversamente, o índice de dureza dos espécimes armazenados em etanol aumentou, indicando o amolecimento do material. Não houve correlação direta entre o índice de desgaste e a dureza do material, pois embora não tenha ocorrido diferença significante nos índices de desgaste em água e etanol das amostras de IPN e Isosit, ocorreu o amolecimento na presença do etanol.

Em 1988, von FRAUNHOFER; RAZAVI; $\mathrm{KHAN}^{57}$ avaliaram novos dentes artificiais de resina modificada com propriedades melhoradas de acordo com o fabricante. Dessa forma, os dentes Isosit (Vivadent) foram comparados aos dentes Bioform IPN (Dentsply) amplamente utilizados na Odontologia. A metodologia usada na pesquisa foi descrita por KHAN; MORRIS; von FRAUNHOFER ${ }^{32}$ em 1984 e as medições foram realizadas a 500, 1000 e 2000 ciclos. A análise dos resultados mostrou que os dentes Isosit apresentaram resistência ao desgaste significantemente maior que os dentes Bioform IPN $(p<0,001)$ em todos os períodos avaliados. O aumento do desgaste entre 500 e 1000 ciclos foi maior que 2,5\% para os dentes IPN, mas menor que 1\% para os dentes Isosit. Entre 1000 e 2000 ciclos, houve um aumento de 1,8 a 3\% no desgaste para os dentes IPN, mas de apenas 0,6 a 1\% para os dentes Isosit. Assim, concluíram que os dentes Isosit recentemente introduzidos no mercado apresentaram aproximadamente 40 a 50\% menos desgaste que os dentes Bioform IPN sob as mesmas condições de teste. 
MCDOWELL et al. $^{35}$ em 1988, desenvolveram o Sistema de Mensuração Coordenado Computadorizado de Michigan para a medição direta do desgaste de materiais in vivo. $O$ sistema foi constituído pela máquina de medição tridimensional de coordenadas Mitutoyo-MX203 acoplada ao sistema de computação Hewlett-Packard. Os programas de computador que operaram o digitalizador foram o Geopak e o Scanpak. O programa Geopak realizou os cálculos para estabelecer a medição das coordenadas em um ponto no espaço e foi capaz de repetir esse ponto nas diferentes amostras e nos variados períodos de avaliação. O programa Scanpak interagiu com os parâmetros estabelecidos pelo programa Geopak e digitalizou a superfície do objeto para mensurar o seu contorno. Foram realizadas trinta e seis digitalizações para coletar aproximadamente 15.000 pontos por dente a cada $0,01 \mathrm{~mm}$ no eixo x e 0,1 $\mathrm{mm}$ ao longo do eixo y, proporcionando o exame tridimensional da superfície. Esses dados foram analisados através do programa Toothscan para a criação da representação gráfica tridimensional do material. Após a digitalização inicial, foi selecionada e calculada uma área de avaliação comum das amostras. A área foi dividida em blocos, os quais foram subdivididos em dois planos triangulares e o volume dentro dos planos superficiais foi calculado. O desgaste por unidade de área foi determinado através da comparação entre duas amostras para cada bloco. O método permitiu a análise acurada da morfologia tridimensional da superfície dentária.

Em 1989, ADAMS; JOOSTE; THOMAS ${ }^{5}$ utilizaram o microscópio reflexo para a mensuração precisa e direta de modelos de dentaduras (análise bioestereométrica). Para a ilustração do método, as características da superfície oclusal do primeiro molar inferior direito de próteses totais duplas em uso clínico foram acompanhadas durante 
um ano. A dentadura superior apresentou dentes anatômicos de porcelana e a inferior dentes mono-planos de resina acrílica. Como pontos de referência, foram utilizados três marcadores de amálgama posicionados na base de resina acrílica atrás dos incisivos centrais e dos últimos molares de cada lado. Como o procedimento de observação foi realizado em uma instituição distante do local de atendimento clínico, a análise direta da dentadura enquanto o paciente aguardava mostrou-se inconveniente e ao mesmo tempo a permissão para que o paciente retornasse à sua casa sem as próteses foi inaceitável. Portanto, foi realizada a moldagem e a obtenção de modelos de gesso das próteses com os marcadores devidamente posicionados. Após um ano e novamente após dois anos de uso contínuo, foram obtidos novos modelos das próteses. Foram registradas aproximadamente 400 coordenadas espaciais na superfície oclusal do dente artificial entre os marcadores de referência e os valores das coordenadas x, y, z no início e no fim da pesquisa. Os dados tridimensionais obtidos foram transferidos para o computador e o programa SACLANT gerou o contorno gráfico e a representação tridimensional dos espécimes a partir da interpolação em malha dos pontos individuais. A diferença entre a altura inicial e final dos contornos gráficos representou o desgaste. A representação tridimensional revelou perda volumétrica do material de $7,2 \mathrm{~mm}^{3}$. A técnica desenvolvida permitiu a quantificação precisa e objetiva do desgaste dentário.

Em 1991, ADAMS; JOOSTE; THOMAS ${ }^{4}$ determinaram a precisão do sistema de duplicação de próteses para a análise bioestereométrica do desgaste de dentes artificiais. O método comparou imagens gráficas do dente original (dente 46) e do modelo obtidas a partir da leitura das coordenadas $\mathrm{x}, \mathrm{y}, \mathrm{z}$ por dois examinadores distintos. Os valores das coordenadas foram processados através de um programa de 
interpolação para gerar o contorno gráfico e a representação tridimensional do elemento dentário. Os resultados revelaram que a diferença volumétrica observada entre o dente real e a sua cópia foi inferior a 0,32 \%. Contudo, essa diferença não foi estatisticamente significante, o que ilustrou a precisão do sistema de duplicação da prótese. Previsivelmente, o maior desvio entre observadores ocorreu na dimensão vertical z, a qual foi dependente da acuidade do observador para a análise estereoscópica. Assim, as limitações no uso da avaliação bioestereométrica de modelos estiveram relacionadas com a precisão dos materiais usados na obtenção das réplicas, a observação visual das cordenadas x, y, z e a conservação dos marcadores de referência.

WRINKLER; MONASKY; KWOK ${ }^{61}$, em 1992 compararam a resistência ao desgaste de três formulações "melhoradas" de resina acrílica de dentes artificiais (Trubyte Bioform IPN, Dentsply.; Orthosit-PE, Ivoclar e Verilux, Universal Dental) com dois produtos convencionais (Bioform, Dentsply e Nuform, Universal Dental). A metodologia empregada para a realização do teste de desgaste utilizou uma máquina de escovação mecânica comumente utilizada na avaliação da qualidade abrasiva de dentifrícios. A máquina foi equipada com seis escovas para permitir o teste simultâneo de seis conjuntos de dentes. A resistência ao desgaste foi avaliada através da perda de peso após o período de escovação (339 horas). Para cada fabricante, foi confeccionado um conjunto constituído por seis dentes posteriores (três superiores direitos e três inferiores esquerdos) imersos em blocos de gesso. Previamente à pesagem, os espécimes foram cuidadosamente removidos dos blocos de gesso, limpos por 15 minutos em lavadora ultrassônica com solução de limpeza, enxagüados em água destilada e por fim acondicionados em um dessecador durante 24 horas. A pesagem dos 
espécimes foi realizada em uma balança analítica eletrônica. Os resultados revelaram que todas as marcas exibiram desgastes insignificantes, embora as marcas convencionais tenham apresentado resistência ao desgaste maior que as formulações "melhoradas".

SATOH et al. ${ }^{50}$, em 1992, realizaram um estudo “in vitro” para avaliar a resistência ao desgaste de dentes artificiais de alta resistência. Foram testados oito tipos de dentes artificiais: três dentes plásticos de alta resistência; dois dentes plásticos convencionais; um dente de porcelana e um dente metálico personalizado. Foram utilizados cinco primeiros pré-molares superiores direitos de cada tipo de dente artificial (totalizando 40 espécimes) e como substratos antagonistas foram confeccionadas 40 placas metálicas de ouro-paládio-prata de 15X15X2 milímetros. A máquina de teste de desgaste permitiu o deslizamento das placas metálicas (presas à parte superior) sobre as cúspides linguais dos espécimes (presas à parte inferior) numa direção mésio-distal à velocidade de 3.000 ciclos/min, com trajetória de três mm sob carga constante de um kgf/dente. A resistência ao desgaste foi avaliada em termos de profundidade de desgaste, perda de peso e análise das facetas de desgaste em microscopia eletrônica de varredura. Os resultados revelaram que a resistência abrasiva dos dentes de alta resistência foi 4,7 vezes a dos dentes convencionais, 0,7 vezes a dos dentes de porcelana e 8,3 vezes a dos dentes metálicos. Em termos de perda de peso, a resistência ao desgaste dos dentes de alta resistência foi 3,3 vezes a dos dentes plásticos, 0,2 vezes a dos dentes de porcelana e 11,4 vezes a dos dentes metálicos. As imagens da microscopia eletrônica de varredura da superfície desgastada revelaram que a extensão da rugosidade foi menor nos dentes de porcelana e de alta resistência seguidos pelos dentes plásticos e 
metálicos. Assim, a resistência ao desgaste foi maior nos dentes de porcelana, seguidos pelos dentes de alta resistência, dentes de resina acrílica convencional e, por fim, os dentes metálicos.

Ainda em 1992, SATOH et al. ${ }^{51}$, publicaram o mesmo estudo anterior acrescentando informações referentes à perda de peso das placas metálicas antagonistas após a realização do teste de desgaste. Os autores concluíram que a perda de peso ocorrida foi mínima quando as placas foram atritadas contra os dentes de alta resistência, mas aumentou nos dentes plásticos, nos dentes de porcelana e nos dentes metálicos.

SATOH et al. $^{49}$, em 1993, investigaram a susceptibilidade dos dentes de alta resistência à ação de corantes. Foram avaliados cinco tipos de dentes artificiais: dois dentes plásticos de alta resistência; dois dentes plásticos convencionais; e um dente de porcelana. Os corantes líquidos empregados no estudo foram: vermelho (2\% de solução aquosa número 102 de corante de alimentos vermelho), marrom (2\% de solução aquosa de café) e amarelo (2\% de solução aquosa de turmérico). Cada tipo de dente artificial foi dividido em três grupos de dez incisivos centrais superiores esquerdos imersos por quatro semanas nos diferentes corantes. Metade dos espécimes de cada grupo foi limpa diariamente através de vibração ultrassônica realizada por limpador ultrassônico em solução de limpeza Ultraclin durante 30 segundos. Então, os grupos individuais foram subdivididos em dois sub-grupos de cinco espécimes cada: com limpeza e sem limpeza. Os corantes foram usados por 24 horas e então substituídos por novos preparados diariamente. A cor dos dentes foi determinada antes (valor controle), uma e quatro 
semanas após a imersão. O sítio de análise da cor foi o ponto de interseção da região mediana das linhas vertical e horizontal na face vestibular dos dentes. A análise da cor foi realizada com um sistema de análise de imagem e uma câmera colorida. O sistema de cor empregado na análise foi $\mathrm{L}^{*}$, a* e b* da diferença de cor CIE1976L*a*b entre os valores de cada ponto de observação e o valor controle. O valor de cada diferença de cor foi multiplicado por 0,92, obtendo o valor do Conselho Nacional de Padronizações, que determina a alteração de cor avaliada pelo olho humano. Os resultados revelaram que os dentes de alta resistência foram menos susceptíveis à pigmentação que os dentes de resina acrílica convencional. Porém, foram acentuadamente mais susceptíveis à pigmentação que os dentes de porcelana. Para todos os tipos de dentes artificiais, a limpeza diária em ultra-som reduziu a pigmentação em comparação com o grupo controle que não recebeu limpeza ultrassônica e o período de quatro semanas pigmentou mais os dentes artificiais do que o período de uma semana.

Em 1993, DOUGLAS; DELONG; PINTADO ${ }^{20}$ avaliaram o índice de desgaste de cinco dentes artificiais: Dentsply Trublend SLM, Dentsply IPN, Vita Vitapan, Ivoclar Orthotyp e Ivoclar Orthosit. Para isso, utilizaram uma boca artificial na qual o ciclo mastigatório entre o primeiro molar inferior artificial e a cúspide palatina do terceiro molar superior humano apresentou a forma de curva hemi-sinuosa sob carga média de $0,7 \mathrm{~kg}$ a quatro $\mathrm{Hz}$ de velocidade, totalizando o total de 300.000 ciclos (aproximadamente 1,2 anos de função clínica) sob lubrificação de água deionizada a 18 litros por hora. O desgaste foi quantificado através da alteração volumétrica da faceta de desgaste medida com o digitalizador de superfície e o programa ANSUR. Os resultados mostraram que a menor perda volumétrica foi observada na marca Trublend SLM, 
seguida por IPN, Orthotyp, Vitapan e Orthosit, sendo que as marcas Trublend SLM e IPN apresentaram desgaste significantemente menor que as outras marcas. Os autores também analisaram a superfície das facetas de desgaste com microscopia eletrônica de varredura para elucidar os mecanismos de desgaste. Os dentes IPN e mais notavelmente, os Trublend SLM, apresentaram baixo desgaste e mantiveram superfícies de alta qualidade após o teste. Apesar da moderada perda volumétrica dos materiais Vitapan e Orthotyp, as imagens revelaram extensivo colapso por fadiga com fraturas profundas e delaminação superficial, especialmente no Orthotyp. A ausência de erosões e fraturas no material Orthosit foi atribuída ao seu acentuado desgaste, o que fez com que a velocidade de desgaste do material fosse maior que o crescimento das fraturas.

LINDQUIST; OGLE; DAVIS ${ }^{34}$, em 1995, realizaram um estudo duplo-cego para comparar o desgaste in vivo de um novo material utilizado na confecção de dentes artificiais com outros materiais pré-existentes. Para isso, 67 indivíduos foram aleatoriamente divididos em três grupos: O grupo I recebeu próteses com dentes de resina modificada SR Vivodent e Orthotyp-PE (Ivoclar). O Grupo II recebeu próteses totais que continham dentes com o novo material experimental Trublend (Dentsply). O Grupo III recebeu próteses totais com dentes de resina IPN (Dentsply). Como material e métodos, os autores utilizaram a máquina de medição coordenada Mitutoyo MXF 203 operada com o computador IBM PS2/55 SX. Essa máquina foi usada para coletar os dados das medições através do sistema de interface MAG-1 e do programa Geopak. Os movimentos dos eixos X-Y foram controlados pelo programa MotionSoft. O cálculo do desgaste foi feito através da comparação entre as diferenças de altura existentes no início do experimento com as medidas tomadas em cada intervalo de tempo. O teste 
ANOVA foi usado para testar a diferença no desgaste médio entre os três grupos desde o início até seis meses e de seis a 12 meses. Os resultados revelaram a inexistência de diferença estatisticamente significativa no desgaste entre os três tipos de dentes artificiais nos intervalos de seis a 12 meses e após 12 meses $(\mathrm{p}<0,05)$. O valor de desgaste total médio em 12 meses foi de $90 \mu \mathrm{m}$. O Grupo I apresentou uma média de $102 \mu \mathrm{m}$ de desgaste, o grupo II apresentou $88 \mu \mathrm{m}$ e o grupo III apresentou $76 \mu \mathrm{m}$ como média de desgaste.

Em 1996, ADAMS et al. ${ }^{3}$ avaliaram o desgaste de próteses de seis indivíduos apresentando dentes de resina acrílica inferiores opostos a dentes de porcelana superiores montados em oclusão lingualizada. Foram obtidos modelos de gesso das superfícies oclusais inferiores em intervalos anuais durante três anos, incluindo os marcadores de referência de amálgama, para a determinação do contorno gráfico através do método previamente descrito pelos autores (análise bioestereométrica). A perda volumétrica do material foi quantificada comparando-se o contorno gráfico inicial com os subseqüentes. Para os indivíduos que não apresentavam lado preferencial para a mastigação, houve diferença estatisticamente significante no lado esquerdo do arco ( $p=0,0085)$, mas não no lado direito $(p=0,093)$ ao longo dos três anos de avaliação. $O$ teste ANOVA revelou a inexistência de diferença estatisticamente significante entre os primeiros pré-molares (34: $\mathrm{p}=0,9 ; 44: \mathrm{p}=0,367)$, mas detectou a presença de diferença significante entre os outros dentes posteriores (35: $0,0085<\mathrm{p}<0,024 ; 45$ : $\mathrm{p}=0,0085$; 36: $\mathrm{p}=0,0085$; 46: $\mathrm{p}=0,0077)$. Um dos indivíduos relatou preferência pela mastigação em um dos lados da arcada, mas apresentou maior desgaste no lado contra-lateral, caracterizando um achado provavelmente associado com atividade para-funcional. Os 
autores concluíram que os dentes de porcelana foram capazes de desgastar severamente os dentes de resina acrílica após três anos de uso clínico, podendo-se utilizar restaurações metálicas oclusais no interior dos dentes artificiais para retardar o desgaste e a conseqüente perda de dimensão vertical de oclusão quando da associação de dentes de porcelana com dentes de resina acrílica.

JOOSTE; GEERTS; GROBLER ${ }^{29}$, em 1996 correlacionaram a dureza e a resistência ao desgaste clínico de seis marcas de dentes artificiais de polimetilmetacrilato opostos a dentes de porcelana. 60 próteses totais, divididas em seis grupos de dez, foram confeccionadas para indivíduos edêntulos. Os modelos iniciais com marcadores nas próteses inferiores foram utilizados para determinar a perda do material dentário bioestereometricamente ao longo de um período de três anos. A dureza Vickers foi obtida através da aplicação de uma carga de 20 g por 30 segundos em cinco pontos nas seis marcas comerciais avaliadas. O teste ANOVA mostrou que as medições do Vitapan $(230,37)$ e Duravite $(207,7)$ foram estatisticamente inferiores a todas as outras marcas. O Duravite foi estatisticamente inferior ao Vitapan. O Acrotone $(264,57)$ e o RX1 $(262,70)$ foram estatisticamente inferiores ao Premierdent $(273,05)(p<0,05)$. Os dentes mais duros não apresentaram a maior resistência ao desgaste. Os dentes mais moles não mostraram a menor resistência ao desgaste.

Em 1997, ABE et al. ${ }^{1}$ realizaram um estudo in vitro para avaliar o desgaste de um tipo de dente artificial de resina composta de alta resistência oposto a oito materiais dentários (resina composta de alta resistência, policarbonato, poliétersulfona, polimetilmetacrilato, liga de ouro-prata-paládio-cobre, liga de cobalto-cromo, cerâmica fundida, 
porcelana feldspática e esmalte humano). Os espécimes (pré-molares) foram presos a blocos de resina de modo que a cúspide vestibular contactou os materiais antagonistas (placas de 10 X 10 X cinco mm). Foi utilizada uma máquina que gerou contato deslizante à velocidade de $20 \times 10^{4}$ a 60 ciclos por minuto com trajetória de quatro mm em direção vestíbulo-lingual sob um Kg de carga. A análise do desgaste foi mensurada como perda de altura e perda volumétrica do material. Os autores também mensuraram três vezes a dureza Knoop em cinco espécimes sob carga de 200 gramas por 30 segundos com um microdurômetro. Os resultados revelaram que a menor diferença de altura foi observada nos espécimes opostos à liga de ouro-prata-paládio, enquanto a maior ocorreu contra a porcelana. Com relação ao volume, a perda volumétrica dos espécimes contra a resina de alta resistência, policarbonato e liga de cromo-cobalto foi significantemente maior do que contra polietersulfona, polimetil-metacrilato, liga de ouro-prata-paládio e esmalte humano. Os achados sugeriram que a resistência ao desgaste dos dentes de resina de alta resistência foi consideravelmente influenciada pelos materiais dentários antagonistas e que a melhor combinação foi resina de alta resistência e liga de ouro-prata-paládio, e a pior foi resina de alta resistência e porcelana. Os dentes de alta resistência apresentaram dureza Knoop de 37 HK.

Ainda no ano de 1997, JOOSTE; GEERTS; ADAMS ${ }^{28}$ realizaram um estudo clínico para avaliar a resistência ao desgaste de seis dentes artificiais de resina acrílica disponíveis comercialmente e uma combinação de dentes de porcelana e resina acrílica. A amostra foi constituída de 70 indivíduos edentados (com idade entre 32 e 64 anos) reabilitados com próteses totais e distribuídos aleatoriamente em sete grupos de dez cada. Foram obtidos modelos iniciais das próteses inferiores, e após três anos de uso, 
obteve-se novos modelos para comparação. Os modelos de gesso foram então submetidos à análise bioestereométrica para determinar a quantidade de desgaste clínico antes e após o uso, a partir do contorno gráfico dos dentes. Não houve diferença estatisticamente significativa entre o desgaste dos dentes artificiais de resina acrílica testados. Os dentes Ivoclar Orthosit apresentaram desgaste significantemente inferior $(\mathrm{p}<0,05)$ aos dentes Vitapan opostos à porcelana. Os dentes Ivoclar Orthosit mostraram o menor grau de desgaste $\left(0,094 \mathrm{~mm}^{3} / \mathrm{mm}^{2}\right)$ seguidos, em ordem, pelo Duravite, Rx1, Vitapan, Acrotone, Premierdent e porcelana/Vitapan $\left(0,259 \mathrm{~mm}^{3} / \mathrm{mm}^{2}\right)$.

Dando continuidade à pesquisa publicada em 1995, OGLE; DAVIS ${ }^{42}$, no ano de 1998, realizaram uma nova avaliação dos mesmos sujeitos da pesquisa com o objetivo de avaliar o desgaste clínico dos dentes artificiais após 36 meses de uso clínico das próteses totais duplas. Para isso, utilizaram a mesma metodologia e os mesmos métodos de pesquisa do estudo anterior ${ }^{34}$. Os resultados revelaram não haver diferença estatisticamente significativa no desgaste médio por gênero $(\mathrm{p}=0,48)$, por material dentário $(\mathrm{p}=0,41)$, em relação à anatomia (dentes anatômicos $\mathrm{X}$ não anatômicos) $(t=1,20, p=0,24)$ e com relação ao lado preferencial da mastigação quando comparado com o desgaste ocorrido no lado não preferencial $(t=1,24, \mathrm{p}=0,22)$. Contudo, houve diferença estatisticamente significante no desgaste por arco $(\mathrm{p}<0,01)$ e também no desgaste por tipo individual de dentes (canino $\mathrm{X}$ primeiro pré-molar $\mathrm{X}$ segundo prémolar X primeiro molar $\mathrm{X}$ segundo molar) $(\mathrm{F}=14,49, \mathrm{p}<0,001)$. Como conclusão, os autores afirmaram que não houve diferença estatisticamente significante entre as três marcas comerciais de dentes de resina modificada avaliadas. 
HIRANO et al. ${ }^{27}$, em 1998, compararam o desgaste in vitro de quatro dentes artificiais: um dente de resina acrílica termo-prensada, um dente de resina acrílica e dois dentes de resina composta. Para isso, cinco amostras por grupo foram submetidas a dois períodos de 5.000 ciclos de desgaste (total=10.000 ciclos) em uma máquina de desgaste em oposição a espécimes de esmalte humano sob 1,4 kg de carga e sob lubrificação com saliva humana. Para a confeccção das amostras de dentes artificiais, realizou-se um corte com um disco paralelo ao plano oclusal de cada dente para gerar uma superfície de teste plana e larga, e prendeu-se as amostras em um bloco de resina acrílica autopolimerizável. As amostras de esmalte foram confeccionadas a partir do corte em formato de pequenos cilindros de uma das cúspides de dentes humanos recém extraídos. Ambas as amostras foram lixadas com lixa de silicone carbide de granulometria 600 e polidas com lixa de silicone carbide de 3,0 $\mu$ m. O desgaste foi mensurado com um perfilômetro em quatro regiões ao longo da trajetória circular criada pelo esmalte na superfície da amostra, sendo relatado como a profundidade máxima em relação à superfície não desgastada. Após 10.000 ciclos, o desgaste dos dentes de resina acrílica (Classic e Kenson) foi substancialmente superior ao desgaste dos dentes compósitos (DB Plus e MLI). Adicionalmente, o desgaste dos dentes Kenson foi também muito maior que os dentes Classic. Não houve diferença estatisticamente significante entre o desgaste dos dentes de resina composta. Concluindo, os autores revelaram que o desgaste dos dentes artificiais de resina composta foi aproximadamente $50 \%$ inferior ao desgaste dos dentes acrílicos.

Em 2001, ABE et al. ${ }^{2}$ avaliaram o desgaste in vitro de cinco materiais utilizados em dentes artificiais posteriores (polimetil-metacrilato, resina composta de alta- 
resistência, liga de ouro-prata-paládio-cobre, liga de cromo-cobalto e porcelana) em contato contra o esmalte humano. Os espécimes dos materiais foram fabricados de forma semelhante aos dentes artificiais de resina acrílica, segundo as instruções do fabricante. Os corpos de prova de esmalte humano (incisivo superior) foram presos a blocos de resina, preparados e polidos de modo a produzir placas de 10 X 10 X 5 mm. A metodologia desse estudo foi a mesma utilizada anteriormente ${ }^{1}$ pelos autores em pesquisa realizada no ano de 1997. A análise do desgaste foi determinada através da perda de altura total determinada pela diferença média de três medições realizadas pelo operador com um paquímetro digital em dois momentos distintos: no início do trabalho e após a realização do teste de desgaste. Os resultados revelaram que a menor perda de altura ocorreu com a combinação polimetil-metacrilato-esmalte e a maior com o par porcelana-esmalte. Houve diferença significante entre o par polimetil-metacrilatoesmalte e todas as outras combinações, excetuando-se o par liga de ouro-prata-paládiocobre-esmalte $(\mathrm{p}<0,05)$. Houve uma correlação significativa entre a perda de altura e a dureza Knoop dos materiais, exceto para a resina de alta resistência. Além disso, também foi avaliada a rugosidade de superfície de cada corpo-de-prova com um rugosímetro (Surfcom 100 A, Tokyo-Seimitsu, Tokyo). O menor valor de rugosidade superficial ( $\mathrm{Ra}$ ) foi encontrado no par resina de alta resistência-esmalte e o maior no par porcelana-esmalte. Também houve significativa correlação entre a rugosidade superficial e a dureza Knoop dos materiais. Esses achados sugeriram que a melhor combinação foi PMMA-esmalte e a pior foi porcelana-esmalte.

Uma das propriedades mais importantes dos dentes artificiais é a capacidade de absorção de parte da energia liberada durante a função mastigatória objetivando reduzir 
a transmissão de forças ao osso de suporte subjacente. O grau de absorção ao choque proporcionado por um material é medido através do valor de impacto oriundo de testes de aceleração. Assim, valores de impacto e de aceleração baixos implicam em menor transmissão de forças à estrutura de suporte subjacente. Além disso, o grau de absorção ao choque parece estar relacionado com a rigidez dos materiais. Baseado nesses conhecimentos, KAWANO et al. ${ }^{30}$ avaliaram no ano de 2002 a absorção ao choque e sua relação com a dureza superficial de dentes artificiais disponíveis comercialmente. Foram testados sete dentes de resina composta, um de resina acrílica e um de porcelana. O instrumento de teste consistiu no aparelho bola em queda-livre associado ao uso de um acelerômetro. Esse aparelho apresentou um eletromagneto que manteve a bola presa e, no momento oportuno, permitiu a sua queda em direção à fossa central dos dentes artificiais. A resposta da aceleração foi captada pelo computador para o cálculo do valor de impacto. A medição da dureza Vickers foi realizada com o indentador micro-Vickers (Akashi) para a determinação do valor médio representativo dos materiais. Os resultados revelaram que os dentes de resina composta mostraram um valor de impacto intermediário entre os dentes de resina acrílica e de porcelana. Os dentes de porcelana apresentaram o maior valor de impacto com diferença estatisticamente significante em comparação aos dentes de resina composta e acrílica testados. Não foi observada diferença significativa entre os dentes de resina composta testados. Foi encontrada uma correlação significativa entre os valores de absorção ao impacto e de dureza Vickers dos dentes artificiais. Assim, os autores sugeriram que os dentes de resina composta e os dentes de resina acrílica apresentaram uma absorção ao impacto maior que os dentes de porcelana. 
NOGUEIRA et al. ${ }^{38}$, em 2002 analisaram a dureza dos dentes artificiais de resina acrílica (Dentron) submetidos a diferentes agentes de limpeza em função do tempo. Os molares artificiais foram incluídos em anéis de PVC com resina acrílica termo-ativada (Lucitone). Após a polimerização e demuflagem foram submetidos ao desgaste e polimento, produzindo uma superfície plana. A medição da dureza Vickers foi feita através do microdurômetro antes e após seis meses de armazenamento das amostras em quatro tipos de soluções: água (controle), clorexidina, hipoclorito de sódio a $1 \%$ e solução caseira de hipoclorito de sódio diluído. Os dados de dez amostras foram submetidos à análise de variância e teste de Tukey, no qual foi apresentada uma redução significativa da dureza superficial dos dentes artificiais imediatamente $(32,93)$ e seis meses após o acondicionamento (20,02). O uso de agentes de limpeza promoveu um efeito sobre os dentes artificiais de resina acrílica similar à imersão em água

No ano de 2003, PAVARINA et al. $^{46}$ avaliaram a influência do uso de três soluções desinfetantes na dureza Vickers de dois dentes artificiais de resina acrílica. Foram utilizados 32 dentes artificiais do mesmo modelo para cada marca, presos axialmente a tubos plásticos com resina para base de dentadura. Após a presa da resina, os espécimes foram lixados com uma seqüência de lixas de silicone carbide de granulação (de 600 a 1200) sob refrigeração à água. Então, as medidas de dureza foram obtidas para todos os espécimes com o microdurômetro sob 100 g de carga por 30 segundos. Foram registradas 12 leituras para cada espécime e o valor médio da dureza calculado. Em seguida, os espécimes foram armazenados em água a $37{ }^{\circ} \mathrm{C}$ por 48 horas e a dureza novamente registrada. Os espécimes foram então aleatoriamente divididos em quatro grupos de oito elementos cada. Nos grupos I, II e III os espécimes foram imersos por dez minutos nas seguintes soluções desinfetantes, respectivamente: 
gluconato de clorexidina a $4 \%$, hipoclorito de sódio a $1 \%$ e perborato de sódio a 3,78 \%, e em seguida enxaguados em água corrente por três minutos. Os espécimes foram desinfetados duas vezes, simulando a condição laboratorial quando as dentaduras são recebidas do paciente e antes de retornarem ao paciente. Os espécimes do grupo IV (grupo controle) foram armazenados em água pelo mesmo período total de 20 minutos. As medições da dureza foram realizadas após a desinfecção dos espécimes e também após o armazenamento final dos espécimes em água a $37^{\circ} \mathrm{C}$ por 15, 30, 60, 90 e 120 dias. Os resultados mostraram não haver diferença estatisticamente significante entre os materiais e as soluções desinfetantes testadas $(\mathrm{p}>0,05)$. Contudo, houve um decréscimo contínuo na dureza relacionado com o tempo de armazenagem dos espécimes em água (p>0,05). Já a redução da dureza superficial de ambas as resinas acrílicas dos dentes artificiais ao longo do tempo de imersão em água provavelmente ocorreu devido ao novelamento das cadeias poliméricas promovido pelas moléculas de água, conduzindo à alteração das características físicas do polímero resultante.

Recentemente, em 2004, SUZUKI ${ }^{54}$ avaliou a dureza e o desgaste de dentes artificiais através de um estudo in vitro. Os dentes foram divididos em quatro grupos de acordo com a composição: resina composta nano-particulada (Veracia), resina composta micro-particulada (SR-Orthosit, Endura, Duradent, Surpass), resina acrílica com ligação cruzada (SR-Postaris, Gênios-P, Creapearl, Vitapan Physiodens, Premium 8, Integral) e resina acrílica convencional (Biotone). O teste de desgaste caracterizou-se por uma haste metálica simuladora de uma cúspide que exerceu carga vertical sobre a superfície do espécime na presença de bolo alimentar artificial durante 100.000 ciclos $(n=10)$. Os valores de profundidade de desgaste foram determinados através de um perfilômetro. As 
áreas da superfície desgastada foram obtidas através do traçado perfilométrico, e calculadas em sistema computadorizado. Para a análise da dureza Knoop $(n=5)$, utilizou-se um microdurômetro sob 25 g durante 30 segundos. Os valores de desgaste variaram entre 90,5 $\mu \mathrm{m}$ para a resina composta nano-particulada, 69,8 a 93,0 $\mu \mathrm{m}$ para a resina composta micro-particulada, 80,8 a 104,0 $\mu$ m para a resina acrílica com ligação cruzada, e 162,5 $\mu \mathrm{m}$ para o dente acrílico convencional. As áreas das superfícies desgastadas foram de 5,1 $\mathrm{mm}^{2}$ para a resina composta nano-particulada, 2,6 a 3,6 $\mathrm{mm}^{2}$ para a resina composta micro-particulada, 4,4 a 5,7 $\mathrm{mm}^{2}$ para a resina acrílica com ligação cruzada e 10,1 $\mathrm{mm}^{2}$ para os dentes de acrílico convencional. Os valores de dureza variaram em torno de 22,7 para a resina composta nano-particulada, 28,2 a 29,8 para a resina composta micro-particulada, 18,9 a 21,6 para a resina acrílica de ligação cruzada, e 18,6 para os dentes de resina acrílica convencional. A análise estatística revelou que o desgaste do dente de acrílico foi significantemente maior que o desgaste sofrido pelos outros dentes artificiais $(\mathrm{p}<0,001)$, que não diferiram entre si. Todos os dentes compósitos micro-particulados foram significantemente mais duros que os outros dentes $(\mathrm{p}<0,0001)$. O dente nano-compósito foi mais duro e mais resistente ao desgaste que o dente acrílico, mas não diferiu significantemente da maioria dos dentes de resina acrílica com ligação cruzada e de resina composta micro-particulada. 


\section{Proposição}

No presente trabalho os autores propuseram-se a:

1) Comparar o valor médio de microdureza Knoop apresentado por três marcas comerciais de dentes artificiais de resina acrílica convencional e quatro marcas de resina acrílica melhorada, em três níveis de profundidade, antes e após a realização da simulação do desafio ácido;

2) Comparar o valor médio de desgaste apresentado por uma marca comercial de dente artificial de resina acrílica convencional e duas marcas de resina acrílica melhorada em função da variação da superfície antagonista (porcelana feldspática glazeada e jateada);

3) Associar as propriedades mecânicas de dureza superficial e resistência ao desgaste dos dentes artificiais. 


\section{Material e Métodos}

Este experimento foi realizado em duas etapas. Na primeira etapa avaliou-se a microdureza superficial de dentes artificiais de resina acrílica de diferentes composições e fabricantes em duas fases distintas: após a imersão dos espécimes em água deionizada e após a realização do protocolo de ciclagem de pH preconizado por FEATHERSTONE et al. $^{22}$, 1986, e modificado por CARVALHO; CURY ${ }^{14}$, 1999, para simulação do desafio ácido ocorrido intra-oralmente. Na segunda etapa foi estabelecida metodologia sensível para a avaliação do desgaste de dentes artificiais através da atrição dos espécimes contra placas metalo-cerâmicas glazeadas e jateadas com partículas de óxido de alumínio. 


\subsection{Mensuração da microdureza superficial Knoop}

\subsubsection{Amostra}

Para a avaliação da microdureza superficial Knoop foram utilizados 70 incisivos centrais superiores artificiais, divididos em grupos de dez, obtidos com fornecedores dos fabricantes da indústria odontológica e divididos da seguinte maneira:

o GRUPO 1: Trubyte Biotone ${ }^{\circledR}$ modelo 266 (Dentsply Indústria e Comércio Ltda, Petrópolis - RJ)

o GRUPO 2: Vipi Dent Plus ${ }^{\circledR}$ modelo 38 (Dental Vipi Ltda. Ind. Com. Imp. e Exp. de Produtos Odontológicos, Pirassununga - SP)

o GRUPO 3: Ivostar ${ }^{\circledR}$ modelo 45 (Ivoclar Vivadent Ltda, Liechtenstein)

o GRUPO 4: Biotone IPN® modelo L99 (Dentsply Indústria e Comércio Ltda, Petrópolis - RJ)

o GRUPO 5: Trilux ${ }^{\circledR}$ modelo E5 (Ruthibras Imp. Exp. e Com. de Materiais Odontológicos Ltda, Pirassununga - SP)

o GRUPO 6: Biolux® modelo 17 (Dental Vipi Ltda. Ind. Com. Imp. e Exp. de Produtos Odontológicos, Pirassununga - SP)

o GRUPO 7: ${ }^{\mathrm{SR}}$ Vivodent ${ }^{\circledR}$ PE modelo A17 (Ivoclar Vivadent Ltda, Liechtenstein) 


\subsubsection{Inclusão}

Para a realização do experimento, cada dente foi unido a um anel de PVC com resina acrílica termo-polimerizável por microondas em forno de microondas convencional em potência máxima (Eletrolux, potência de 1400 W, freqüência de microondas 2400, Sanyo da Amazônia, Amazonas, Brasil). Para isto, anéis de PVC de 6,0 mm de altura e $20 \mathrm{~mm}$ de diâmetro, obtidos a partir do corte de canos de PVC (Tigre, São Paulo, SP) em máquina de serralheria, foram inicialmente preenchidos com cera 7 fundida (Polidental Ind. Com. LTDA, SP). Para tal, os anéis foram dispostos sobre uma placa de vidro (JON Com. de Produtos Odontológicos LTDA, São Paulo, SP) previamente isolada com vaselina sólida (Hemafarma Com. e Ind. Farmacêutica Ltda, São Gonçalo, RJ), e a cera 7 fundida vertida em seu interior. Imediatamente após o resfriamento da cera, realizou-se o seu alisamento superficial com lâmina de estilete e os padrões foram incluídos em mufla específica para forno de microondas (Vipi Ind. e Comércio Prod. Odontológicos LTDA, Pirassununga, SP), previamente isolada com vaselina sólida. Durante o procedimento, foram incluídos cinco cilindros por mufla (FIGURA 1) com gesso comum (Gesso - Rio, Rio Claro, SP) manipulado em cuba de borracha (Dentalbrand Comercial) com espátula para gesso (Indusbello Ind. de Instr. Odontológicos, Londrina, Paraná).

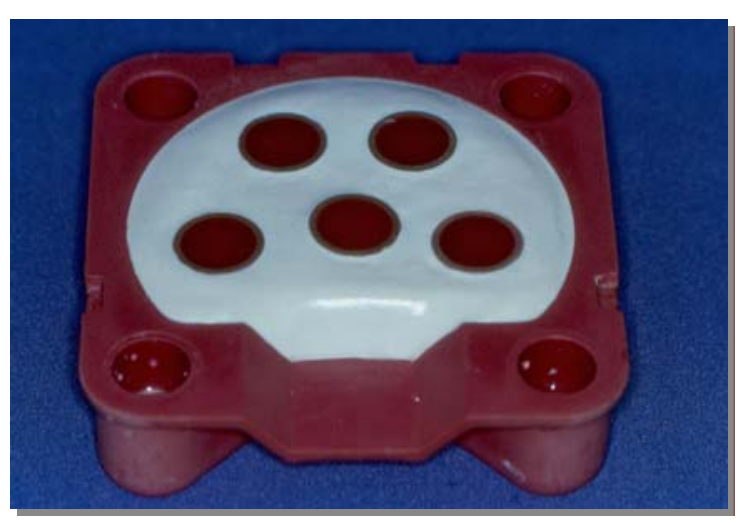

FIGURA 1 - Inclusão na mufla 


\subsubsection{Eliminação da cera}

Quarenta minutos após a inclusão dos anéis, cada mufla foi levada ao forno de microondas por 40 segundos para o amolecimento da cera. Em seguida, a mufla foi aberta para que a cera amolecida fosse removida com o auxílio de espátula $n^{\circ} 31$ (SS White Art. Dentários LTDA, RJ). Com o intuito de remover completamente quaisquer vestígios de cera, o interior dos anéis foi preenchido com algodão hidrófilo (Apolo, Cia. Manufatora de Tecidos de algodão, Cataguases, MG), a mufla novamente fechada com seus respectivos parafusos e procedeu-se a realização de um novo ciclo no forno de microondas durante três minutos. A mufla foi então mais uma vez aberta para eliminação do algodão com os resquícios de cera absorvidos, propiciando desta forma a limpeza completa no interior dos anéis de PVC.

\subsubsection{Termo-acrilização}

Após a eliminação da cera do interior dos anéis, procedeu-se o isolamento de toda a superfície do gesso com isolante para resina acrílica (Cel-Lac, S.S. White Artigos Dentários, RJ) com o auxílio de pincel de pêlo de marta (Tigre, São Paulo, SP). A resina acrílica (Onda-Cryl, Artigos Odontológicos Clássico, São Paulo, SP) foi homogeneizada com o auxílio de espátula nº 31 em recipiente de vidro (Paladon, Pr. Ind. e Comércio de Produtos Odontológicos, Florianópolis) utilizando-se a proporção de uma porção de pó para uma de líquido, mensuradas com o pote dosador fornecido pelo fabricante. O interior dos anéis foi preenchido com a resina acrílica na fase arenosa e as amostras de dentes foram imersas individualmente no interior de cada anel, tomando-se o cuidado de deixar a face vestibular voltada para cima. A base da mufla foi coberta com uma folha de papel celofane e fechada com a sua respectiva porção superior para 
ser prensada em prensa hidráulica (VH Equipamentos Médicos Odont. Acess. LTDA., Araraquara, SP) sob carga inicial de $500 \mathrm{Kg}$. No momento em que o ponteiro da prensa hidráulica apresentou-se estável, a carga foi aumentada para 750 Kg e, por fim, para 800 Kg. Após a estabilização do ponteiro em $800 \mathrm{Kg}$ e o escoamento completo do excesso de resina acrílica, a mufla foi novamente aberta, o papel celofane removido e a película de resina acrílica excedente eliminada com o auxílio de uma espátula Lecron (SS White Art. Dentários LTDA, RJ). A mufla foi novamente fechada e levada para a prensa hidráulica sob cargas seqüenciais de 500, 750 e 800 Kg e deixada por uma hora sob 800 Kg de pressão, de acordo com as recomendações do fabricante. Após esse período, a mufla foi conduzida para o forno de microondas para que se procedesse à termoacrilização com a seguinte programação: Tempo I: três minutos à potência quatro; Tempo II: quatro minutos à potência zero e Tempo III: três minutos à potência nove. Em caso de termo-acrilização simultânea de duas muflas no forno de microondas, foi necessário alterar apenas o Tempo III para quatro minutos à potência nove.

\subsubsection{Demuflagem}

Após a acrilização das amostras, as muflas foram removidas do forno de microondas e deixadas sobre a bancada para esfriar por um período de aproximadamente quatro a cinco horas. Após o resfriamento completo, procedeu-se à demuflagem dos espécimes. Realizou-se a remoção dos excessos grosseiros com lixa de silicone carbide de granulação 320 (Extec Corp., Enfield, USA) com refrigeração a água em politriz metalográfica manual (APL 4, Arotec, Cotia, SP), buscando-se deixar as superfícies superior e inferior do espécime paralelas entre si (FIGURAS 2 e 3). 


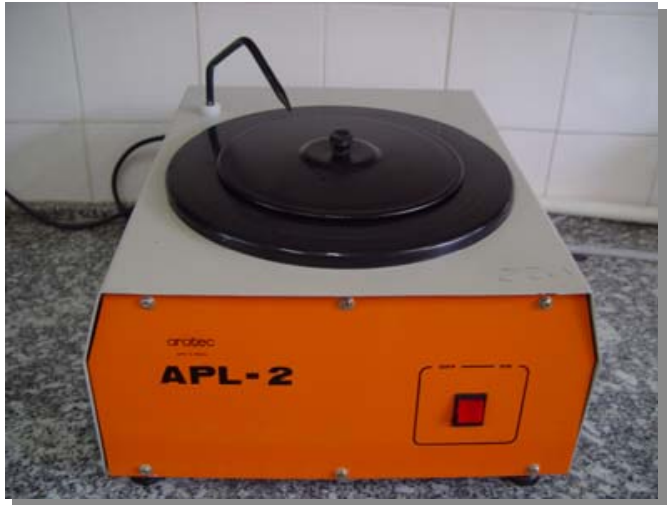

FIGURA 2 - Politriz Metalográfica Manual

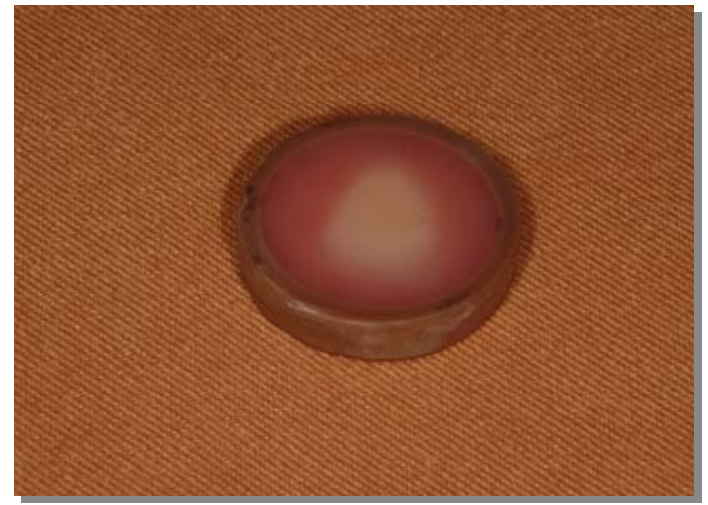

FIGURA 3 - Espécime acrilizado

\subsubsection{Secção dos espécimes}

Visando a análise da microdureza superficial em diferentes níveis de profundidade, cada espécime foi seccionado transversalmente em um aparelho de corte de precisão ISOMET 1000 Precision Saw (Buehler Ltd., Lake Bluff, IL, USA) com um disco diamantado dupla face - XL 12205, “High concentration”, 102 X 0,3 X 12,7 mm (Extec Corp., Enfield, CT, USA/Ref: 12205) à velocidade de 300 rpm, refrigerado com água (FIGURA 4), obtendo-se duas metades e quatro superfícies para a análise da microdureza em cada espécime (FIGURA 6). Devido ao pequeno tamanho, a superfície correspondente à região do cíngulo foi descartada. Assim sendo, as superfícies analisadas equivaleram à face externa (face 1) e às duas faces internas dos dentes artificiais (faces 2 e 3). 


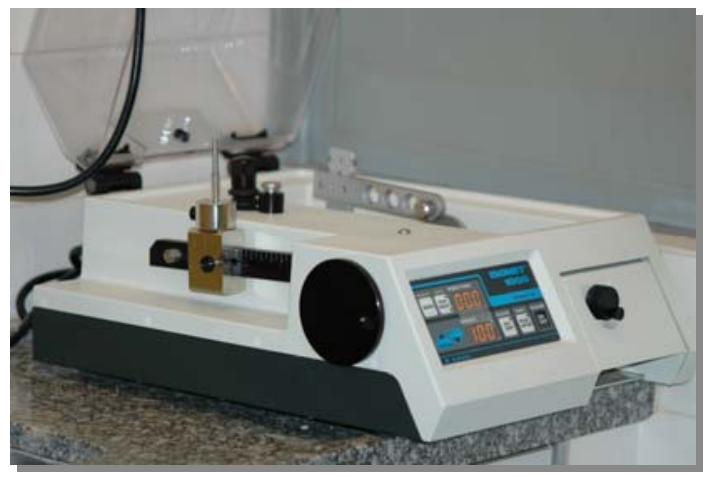

FIGURA 4 - Máquina de corte

\subsubsection{Planificação e polimento dos espécimes}

Utilizando-se uma espátula nº 7 (SS White Art. Dentários LTDA, RJ) e uma lamparina (JON, Ind. Bras.), cada face do espécime foi fixada num disco de acrílico cristal (30 mm de diâmetro por oito mm de espessura) com cera pegajosa plastificada (Kota Ind. e Com. Ltda., São Paulo, SP) para permitir a montagem na politriz metalográfica (FIGURA 5), que possuía um sistema de polimento múltiplo capaz de realizar o trabalho simultâneo em seis corpos de prova, com refrigeração de água deionizada, permitindo o paralelismo entre as superfícies polidas e o disco de acrílico cristal onde foram fixados os espécimes seccionados (FIGURA 6).

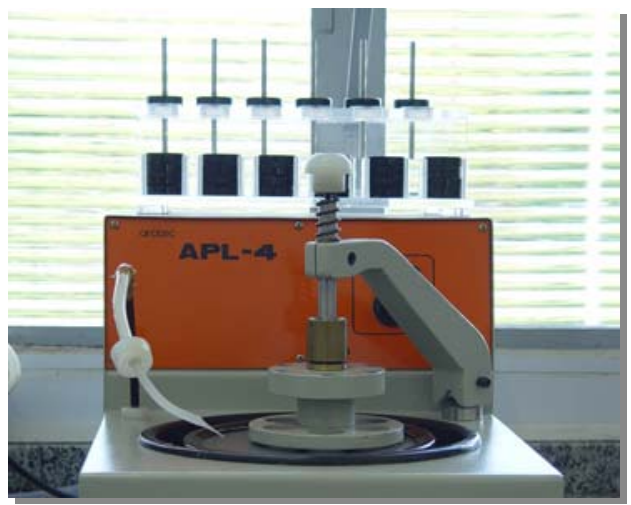

FIGURA 5 - Politriz Metalográfica com sistema de polimento múltiplo

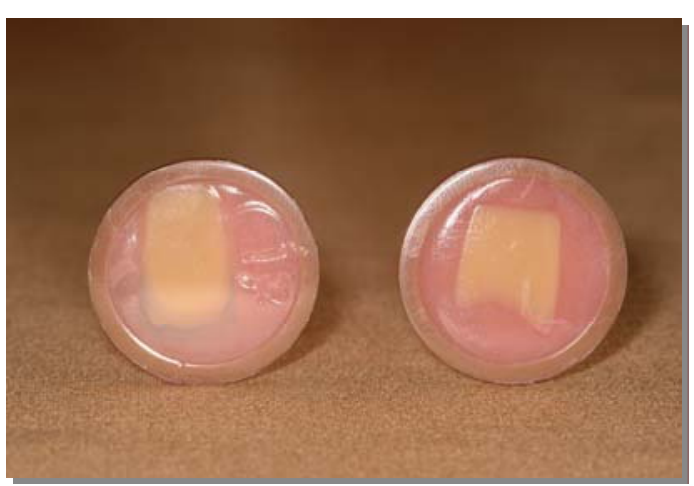

FIGURA 6 - Espécime do teste de dureza seccionado ao meio 
A planificação das faces iniciou-se com lixa de silicone carbide de granulação 320, acionando-se a politriz em baixa velocidade e com dois pesos padrão de 86 g, durante dez minutos. Seguiu-se o polimento com lixa de granulação 600 durante cinco minutos com a mesma velocidade e carga anteriores e lixa 1200 em alta velocidade também com 86 g de carga por mais cinco minutos. Para finalizar o polimento, utilizouse um feltro (Extec Corp., Enfield, USA) umedecido com suspensão de alumina de 0,3 $\mu \mathrm{m}$ (Buehler, Enfield, USA) por dois minutos, em velocidade alta, com quatro pesos padrão de 86 g e sem refrigeração.

Com o objetivo de impedir que os grãos das primeiras lixas interferissem na qualidade do polimento das seguintes, a cada troca de granulometria, o conjunto dente/disco foi levado para limpeza em uma lavadora ultra-sônica T7 Thornton (Unique Ind. e Com. de Produtos Eletrônicos Ltda., São Paulo, SP), com freqüência de 40 Hz, durante dois minutos, com água destilada deionizada, sendo depois lavado em água corrente e deixado secar à temperatura ambiente.

Após o polimento de cada face, a metade do espécime foi removida do disco de acrílico, todo o resíduo de cera pegajosa aderido a ela eliminado e, então, novamente fixada com cera pegajosa no centro do disco de acrílico com o objetivo de realizar o polimento da outra face, repetindo-se todo o protocolo.

\subsubsection{Análise da microdureza superficial dos espécimes}

Para a realização dos testes de dureza inicial, os espécimes foram imersos em água deionizada por um período de 48 horas e deixados secar a $37^{\circ} \mathrm{C}$ durante 24 horas em um controlador microprocessado modelo 502 C ORION (Fanem, São Paulo). 
Após o período de armazenamento em água, as medições de dureza iniciais foram obtidas com o microdurômetro (HMV - 2000 / Shimadzu Corporation, Japan) acoplado a um microcomputador e um software específico para a análise das imagens (Cams-Win-New Age Industries / USA). O microdurômetro acionou uma ponta penetradora de diamante com forma piramidal de base losangular sob carga vertical estática de 200 g aplicada por 30 segundos e a leitura foi realizada com a objetiva de 10X (FIGURA 7).

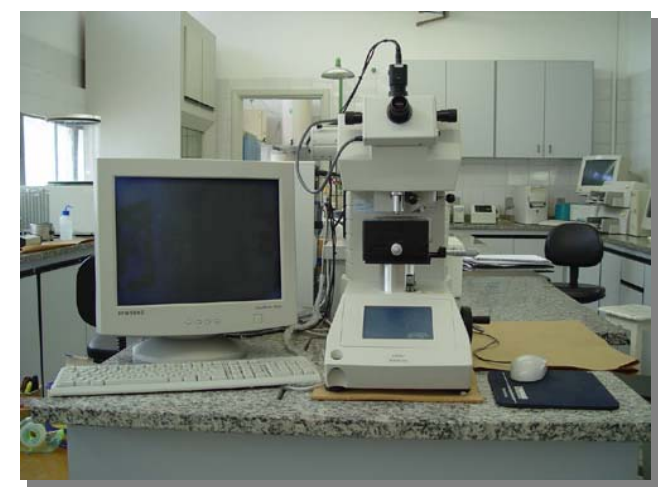

FIGURA 7 - Microdurômetro

Quando acionado, o penetrador realizou uma compressão na superfície do espécime, gerando uma figura geométrica em forma de losango, visualizada pelo contraste entre a impressão e a superfície (FIGURA 8).

O losango possibilita a determinação da microdureza superficial do material a partir da mensuração de sua maior diagonal, cujo valor é aplicado em uma fórmula matemática para obtenção dos resultados. O microdurômetro usado no experimento realiza os cálculos automaticamente, a partir de duas marcas pontilhadas que surgem na tela do computador sobrepostas aos vértices agudos do losango. Assim, o resultado da dureza KNOOP aparece no monitor do microcomputador através do cálculo feito pelo software da seguinte equação: $\quad \mathrm{KHN}=\underline{\text { C.C }}$ 
Sendo: $\mathrm{KHN}$ = valor de dureza Knoop

C $($ constante $)=14,230$

$c=200$ gramas

d = comprimento da maior diagonal da endentação

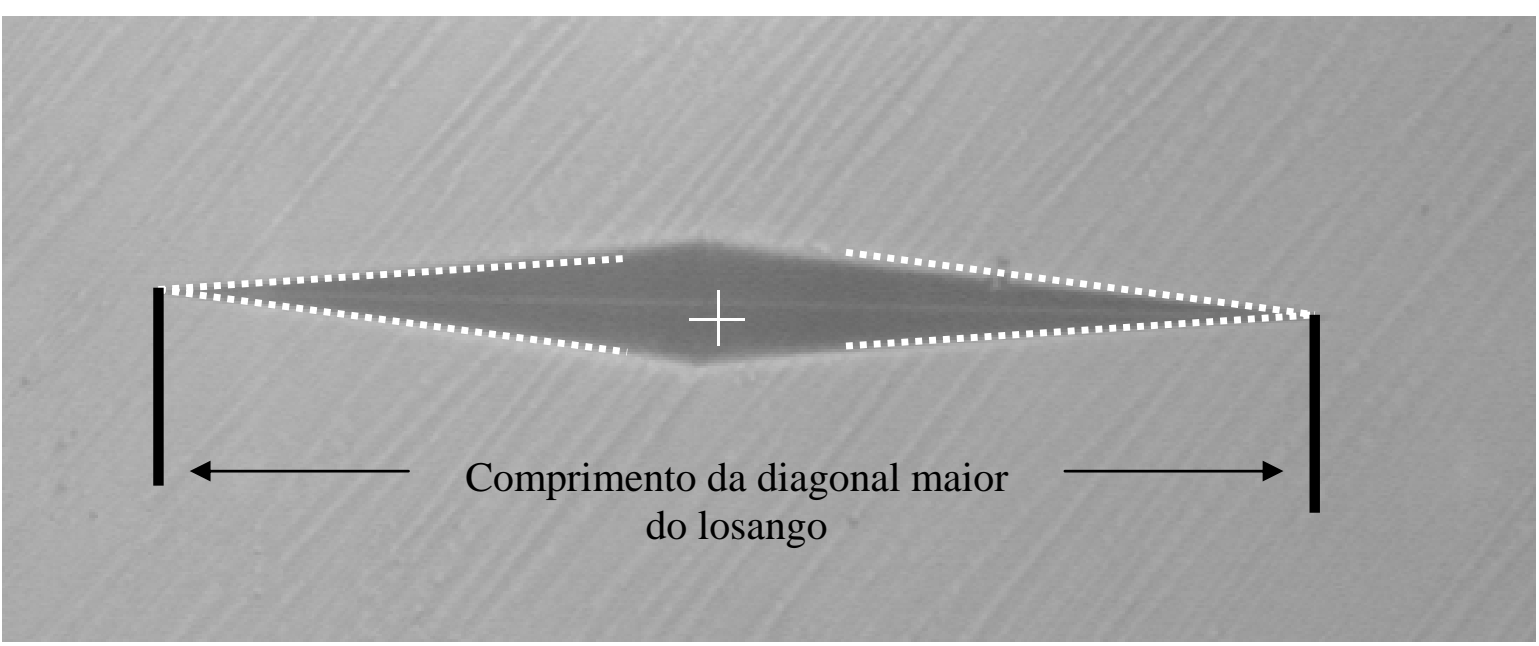

FIGURA 8 - Imagem de uma compressão realizada para avaliação da microdureza em aumento de $10 \mathrm{X}$.

Foram realizadas três compressões por terço dentário (cervical, médio e incisal) nas três faces, no total de nove em cada uma e 27 por espécime.

Após a análise da dureza inicial, os espécimes foram submetidos à ciclagem de pH para a determinação da dureza final através da realização de novas medições de impressões obtidas também nos três terços dentários das três faces de cada espécime, próximas às iniciais, para tentar se padronizar ao máximo o sítio de análise.

Os espécimes foram submetidos a ciclos dinâmicos de $\mathrm{pH}$ de acordo com o protocolo proposto por FEATHERSTONE et al. ${ }^{22}$, 1986, e modificado por CARVALHO; CURY ${ }^{14}, 1999$, para a simulação do desafio ácido ocorrido na cavidade oral. A ciclagem de pH corresponde ao uso de solução ácida por seis horas intercalada com saliva artificial por 18 horas durante 14 dias. Cada secção do espécime foi 
primeiramente imersa em cinco mililitros de solução ácida por seis horas à temperatura ambiente. Após esse período, a solução ácida foi eliminada e os hemi-espécimes foram imersos em cinco mililitros de saliva artificial por um período de 18 horas à temperatura ambiente. Esse padrão de ciclagem foi repetido durante 15 dias consecutivos. A solução ácida consistiu em 2,0 mM de Cloreto de Cálcio e 2,0 mM de Fosfato de Potássio em solução de 75,0 mM de Ácido Acético com pH de 4,3. A saliva artificial consistiu em 1,5 mM de Cloreto de Cálcio, 0,9 mM de Fosfato de Potássio e 150 mM de Cloreto de potássio em solução de 20 mM de hidroximetil-aminometano em pH 7,0.

Preparou-se volume suficiente da solução ácida (dez litros) em função do número de espécimes. Para o preparo de cada três litros da solução ácida, inicialmente pesou-se em balança analítica Sartorius (Werke A.G., Alemanha - com precisão de 0,0001 g) 0,882 g de Cloreto de Cálcio e 1,0452 g de Fosfato de Potássio. Com o auxílio de uma pipeta de vidro (Pyrex, USA), mediu-se o volume de 12,8676 ml de Ácido Acético Glacial 1,0 M (Merck, Darmstadt - Germany). Em seguida, todos esses componentes foram transferidos para um Becker (Pyrex, USA), contendo dois litros de água deionizada e os sais foram dissolvidos sob agitação constante com o auxílio de um agitador magnético PC-420 (Corning, USA). Adequou-se o pH 4,3 da solução ácida com hidróxido de sódio nuclear (Merck, Darmstadt - Germany) e o auxílio de um pHâmetro B371 (I-micronal, Ind. Brás., São Paulo, SP). O pH-âmetro é um aparelho que possui uma extremidade sensível às variações de pH que quando imersa em soluções, acusa em uma unidade receptora o seu potencial hidrogeniônico. Por fim, acrescentouse um litro de água deionizada à solução preparada para completar o volume de três litros em balão volumétrico (Pyrex, USA) e agitou-se até a obtenção da homogeneidade da solução. 
Para o preparo da saliva artificial, também foi calculada a proporção de cinco mililitros por espécime, perfazendo o total de 10 litros de solução. Para o preparo de cada três litros de saliva artificial, inicialmente pesou-se em balança analítica eletrônica 0,6612 g de Cloreto de Cálcio, 0,4704 g de Fosfato de potássio, 33,552 g de Cloreto de Potássio e 7,4228 g de hidroximetil-aminometano (TRIS). Em seguida, todos esses componentes foram transferidos para um Becker, contendo dois litros de água deionizada e os sais foram dissolvidos sob agitação constante novamente com o auxílio de um agitador magnético. Adequou-se o pH 7,0 com ácido clorídrico (Merck, Darmstadt - Germany) com o auxílio de um pH-âmetro. Por fim, acrescentou-se um litro de água deionizada à solução preparada para completar o volume de três litros em balão volumétrico e agitou-se até a obtenção da homogeneidade da solução.

As formulações foram repetidas até a obtenção da quantidade desejada das soluções desmineralizadora e remineralizadora.

Por fim, foram obtidos os valores médios de dureza dos espécimes antes e após a realização do desafio ácido para classificar a perda de dureza ocorrida nas diferentes marcas comerciais nas diversas faces e fases analisadas. 


\subsection{Mensuração da resistência ao desgaste}

\subsubsection{Amostra}

Para a análise da resistência ao desgaste foram utilizados 60 caninos superiores artificiais obtidos com fornecedores dos fabricantes da indústria odontológica. Os dentes foram atritados contra substratos antagonistas equivalentes a 30 placas metalocerâmicas glazeadas e 30 placas metalo-cerâmicas jateadas com partículas de óxido de alumínio (100 $\mu$ m de diâmetro). As amostras e suas respectivas superfícies antagonistas foram divididas em grupos de dez da seguinte maneira:

o GRUPO 1: Trubyte Biotone ${ }^{\circledR}$ modelo 266 (Dentsply Indústria e Comércio Ltda, Petrópolis - RJ) atritado contra placas metalo-cerâmicas glazeadas.

o GRUPO 2: Trubyte Biotone ${ }^{\circledR}$ modelo 266 (Dentsply Indústria e Comércio Ltda, Petrópolis - RJ) atritado contra placas metalo-cerâmicas jateadas.

o GRUPO 3: Trilux ${ }^{\circledR}$ modelo E5 (Ruthibras Imp. Exp. e Com. de Materiais Odontológicos Ltda, Pirassununga - SP) atritado contra placas metalo-cerâmicas glazeadas.

o GRUPO 4: Trilux ${ }^{\circledR}$ modelo E5 (Ruthibras Imp. Exp. e Com. de Materiais Odontológicos Ltda, Pirassununga - SP) atritado contra placas metalo-cerâmicas jateadas.

o GRUPO 5: ${ }^{\mathrm{SR}}$ Vivodent ${ }^{\circledR}$ PE modelo A17 (Ivoclar Vivadent Ltda, Liechtenstein) atritado contra placas metalo-cerâmicas glazeadas. 
o GRUPO 6: ${ }^{\mathrm{SR}}$ Vivodent ${ }^{\circledR}$ PE modelo A17 (Ivoclar Vivadent Ltda, Liechtenstein) atritado contra placas metalo-cerâmicas jateadas.

\subsubsection{Confecção dos espécimes}

Cada dente artificial foi preso à cabeça de uma escova de dente modelo Standard (Sorriso Kolynus ${ }^{\circledR}$, Colgate-Palmolive Ind. e Com. Ltda, S. B. Campo, SP), após a remoção das cerdas com um alicate. Para isso, confeccionou-se um orifício em formato quadrangular na cabeça da escova com uma broca de aço tronco-cônica n $n^{\circ} 703$ (KG SORENSEN Ind. Com. LTDA, São Paulo, SP) montada em peça de mão (Dabi Atlante, São Paulo, SP) e uma cavidade retentiva na região cervical dos dentes artificiais com broca de aço esférica no 3 (KG SORENSEN Ind. Com. LTDA, São Paulo, SP) e, por meio de um parafuso e resina composta (TPH, Dentsply, Petrópolis, RJ), fixou-se o dente artificial à cabeça da escova (FIGURA 9).

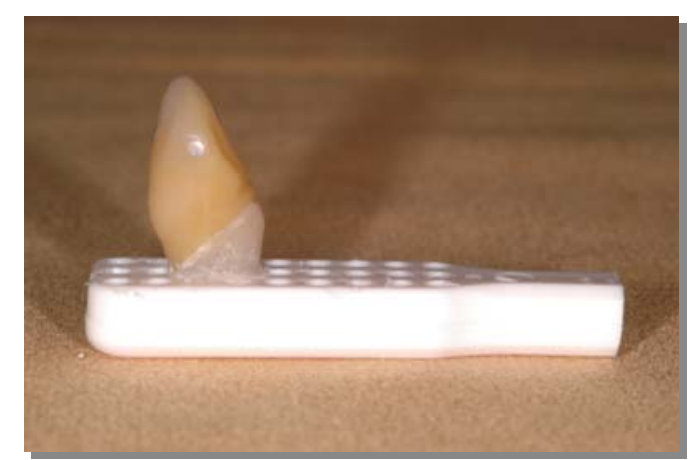

FIGURA 9 - Espécime do teste de desgaste

\subsubsection{Determinação dos pontos de referência}

A resistência ao desgaste dos espécimes foi determinada pela análise comparativa da altura dos dentes antes e após a realização do teste de desgaste. 
Objetivando o estabelecimento de quatro pontos de referência fixos e estáveis para a realização das medições da altura dentária, foram confeccionadas cavidades retentivas com broca diamantada cone-invertido número 1031 (KG Sorensen Ind. Com. Ltda Barueri - SP) montada em turbina de alta rotação (Dabi Atlante, São Paulo) na região mediana das faces vestibular, palatina, mesial e distal de cada dente, e essas cavidades foram preenchidas com liga de amálgama de prata em cápsulas (SDI, Austrália).

O amálgama em cápsulas foi preparado em um amalgamador (SDI, Austrália) e dispensado em um pote Dappen de vidro (Pr. Ind. e Comércio de Produtos odontológicos, Florianópolis). Em seguida, as cavidades retentivas dos dentes foram preenchidas com a liga com o auxílio de um porta-amálgama (SS White Art. Dentários LTDA, RJ) e um condensador (SS White Art. Dentários LTDA, RJ). Os excessos do material foram eliminados com uma espátula Hollemback (SS White Art. Dentários LTDA, RJ) e, após 24 horas, realizou-se o polimento superficial com o Kit Polimento de Amálgama Viking (KG Sorensen, Ind. Com. Ltda - Barueri - SP) montado em contra-ângulo e motor de baixa rotação (Dabi Atlante, São Paulo, SP).

\subsubsection{Determinação do comprimento dentário inicial}

O aparelho usado para a medição foi o microscópio comparador (TM-505, Mitutoyo Corporation, Japão) com objetiva de menor aumento (10X). Esse aparelho apresenta os eixos de medição horizontal (x) e vertical (y), sendo que o ponto de cruzamento entre os dois eixos é o ponto de referência para a medição (FIGURA 10).

O comprimento dos dentes foi medido em cada face entre dois pontos de referência (o ponto de amálgama e a ponta de cúspide dentária), caracterizando o comprimento inicial. Inicialmente a linha tracejada horizontal (eixo x) foi movimentada 
verticalmente até tangenciar a borda mais inferior do ponto de amálgama. Em seguida, a linha tracejada vertical (eixo y) foi deslocada no sentido horizontal até cruzar o ponto de tangenciamento da linha tracejada horizontal com o bordo inferior do amálgama. Nesse instante o aferidor digital do microscópio medidor foi zerado. Em seguida, todo o procedimento acima foi repetido até que o ponto de cruzamento entre as linhas tracejadas horizontal e vertical tangenciasse a porção mais inferior da ponta de cúspide dos caninos, anotando-se o valor registrado $(\mathrm{mm})$. Foram realizadas três medições seqüenciais para cada face dos espécimes (vestibular, palatina, mesial e distal) com o objetivo de minimizar os erros durante a medição, totalizando 12 medições por espécime. Posteriormente foram obtidas as médias da altura dentária inicial dos espécimes por face.

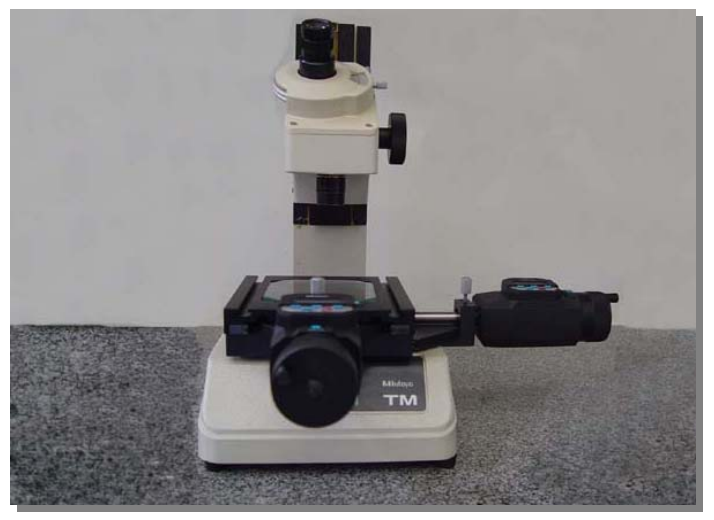

FIGURA 10 - Microscópio Comparador

\subsubsection{Confecção das placas metalo-cerâmicas antagonistas}

Foram confeccionadas 60 placas retangulares metalo-cerâmicas que atuaram como substrato antagonista para a atrição dos espécimes. As placas metálicas foram obtidas a partir da fundição de padrões de acetato de $2,5 \mathrm{~cm}$ de comprimento X 1,2 cm 
de largura $\mathrm{X}$ 0,15 cm de espessura com liga de Níquel-Cromo DURABOND ${ }^{\circledR}$ UNIVERSAL (Odonto Comercial Importadora Ltda).

Para a obtenção dos padrões de acetato utilizou-se um pantógrafo, que consiste em um equipamento dotado de uma fresa com capacidade de realizar desgastes com extrema precisão. Dessa forma, a partir de matrizes de acetato de um milímetro e meio de espessura (Bioart Equip. Odontológicos LTDA, São Carlos), o pantógrafo delineou padrões com formato de placas retangulares e escavou o espaço de 0,6 $\mathrm{mm}$ para a aplicação da porcelana.

Após a fundição dos padrões de acetato, a porcelana feldspática Duceram ${ }^{\circledR}$ Plus (DeguDent Ind. Com. Ltda, Catanduva, SP) foi aplicada nas placas metálicas de NíquelCromo e sinterizada em forno a vácuo (Vulcano, EDG, São Carlos, São Paulo) (FIGURA 11). Nas duas primeiras queimas aplicou-se a pasta de opaco à temperatura inicial de $600{ }^{\circ} \mathrm{C}$, sendo elevada até $940{ }^{\circ} \mathrm{C}$. Em seguida, foram realizadas mais duas queimas para a sinterização da própria porcelana, sendo que a temperatura da primeira queima foi de $600^{\circ} \mathrm{C}$, sendo posteriormente elevada até $930{ }^{\circ} \mathrm{C}$, e a temperatura da segunda queima iniciou-se em $600{ }^{\circ} \mathrm{C}$ e atingiu $920^{\circ} \mathrm{C}$ no final.

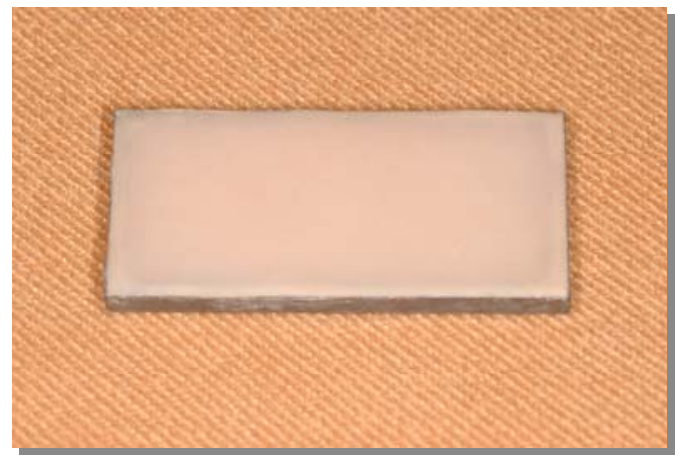

FIGURA 11 - Placa metalo-cerâmica antagonista 
Após a aplicação da porcelana, as placas metalo-cerâmicas foram presas a discos de acrílico cristal com cera pegajosa e instrumento PKT e então planificadas e polidas em politriz manual (FIGURA 2) com lixas de silicone carbide de granulometrias 180, 240, 320 e 600 (Extec Corp., Enfield, USA).

A cada troca de lixa as placas metalo-cerâmicas foram levadas à lavadora ultrasônica, com freqüência de $40 \mathrm{~Hz}$, durante dois minutos em água destilada e em seguida lavadas em água corrente e deixadas secar à temperatura ambiente.

Objetivando-se simular a prática clínica, foram utilizadas placas metalocerâmicas como substratos antagonistas apresentando dois diferentes tipos de tratamento superficial: glazeamento e jateamento. As placas metalo-cerâmicas glazeadas foram obtidas através da realização de uma etapa adicional de queima após a planificação e o polimento da cerâmica a $920^{\circ} \mathrm{C}$ (glaze natural). Já as placas metalocerâmicas jateadas foram obtidas através do jateamento com partículas de óxido de alumínio de 100 ㅆm de diâmetro (VH Equipamentos Médicos. Odont. Acess. LTDA., Araraquara, SP) de toda a superfície cerâmica após a planificação e o polimento.

\subsubsection{Confecção das bases estabilizadoras de resina acrílica}

Para que as placas metalo-cerâmicas permanecessem estabilizadas na máquina durante a realização do ensaio e não ocorressem micro-movimentos, foram confeccionadas bases de estabilização de resina acrílica auto-polimerizável incolor (Jet, Artigos Odontológicos Clássico, São Paulo, SP). Dessa forma, cada placa metalocerâmica foi fixada com resina acrílica no interior dessas bases estabilizadoras e em seguida, o conjunto foi reembasado com resina acrílica diretamente na parte inferior do equipamento, obtendo-se a estabilização. 
Para a confecção das bases de acrílico, inicialmente obteve-se um padrão de

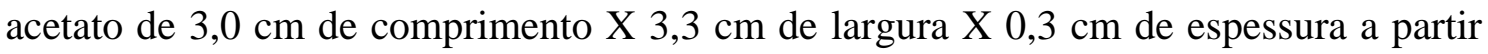
do recorte de uma matriz de acetato com disco de carburundum (Labordental LTDA, São Paulo, SP) montado em peça de mão e colagem dos pedaços com adesivo de éster de cianocrilato (Super Bonder, Henkel Ltda, Ind. Bras.) no formato de uma caixa.

Para a reprodução desse padrão de acetato, confeccionou-se um molde com silicone de adição Elite (Labordental LTDA, SP). Para isso, uma muralha de cera utilidade foi colocada ao redor do padrão e o silicone de adição vazado no seu interior. Aguardou-se a polimerização do silicone de adição e obteve-se o molde de silicone correspondente ao negativo do padrão de acetato original. Dessa forma, através da utilização desse molde, foi feita a reprodução em escala de 60 bases estabilizadoras de acrílico. Para tal, manipulou-se a resina acrílica auto-polimerizável com uma espátula $\mathrm{n}^{\circ}$ 31 em um pote de vidro e verteu-se a mistura no interior do molde de silicone, comprimindo-se o acrílico com uma placa de vidro previamente isolada com vaselina sólida até a polimerização, quando se procedeu à remoção dos excessos com fresa em formato de pêra (Dentsply Ind. Com. LTDA, Petrópolis, RJ) montada em peça de mão.

\subsubsection{Adaptação da máquina de escovação em máquina de desgaste}

Buscando um método reproduzível para a avaliação do desgaste de dentes artificiais, adaptou-se uma máquina de escovação disponível comercialmente e idealizada por TURSSI ${ }^{56}, 2001$.

Originalmente, a máquina apresentava um motor que realizava movimentos de vai-vem em dez braços (onde eram fixadas as cabeças das escovas dentais), permitindo a escovação superficial e simultânea de dez corpos de prova posicionados na base de 
aço inoxidável. O equipamento era dotado de um sensor de temperatura para a manutenção dos espécimes a $37+/-2{ }^{\circ} \mathrm{C}$ durante a realização do ensaio e de uma cúpula de vidro que permitia o monitoramento do experimento.

A adaptação da máquina de escovação em máquina de desgaste foi obtida da seguinte maneira: nos braços da máquina (parte superior móvel) fixou-se a cabeça da escova com o dente artificial e na base do equipamento (parte inferior fixa) foram fixadas as placas metalo-cerâmicas antagonistas (FIGURAS 12 e 13).

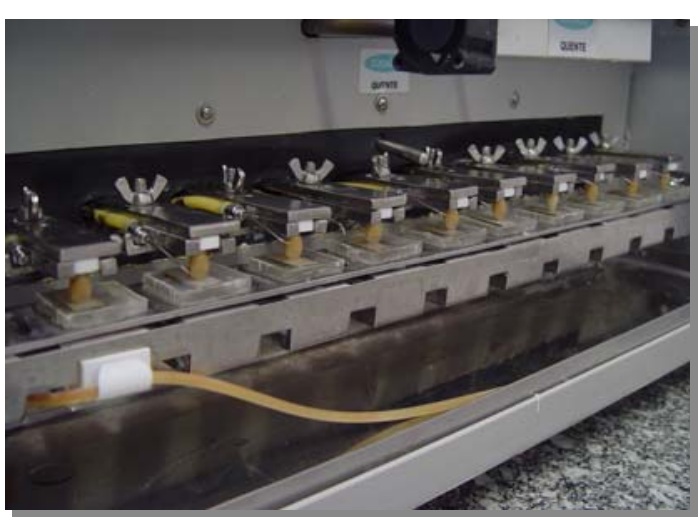

FIGURA 12 - Máquina de desgaste

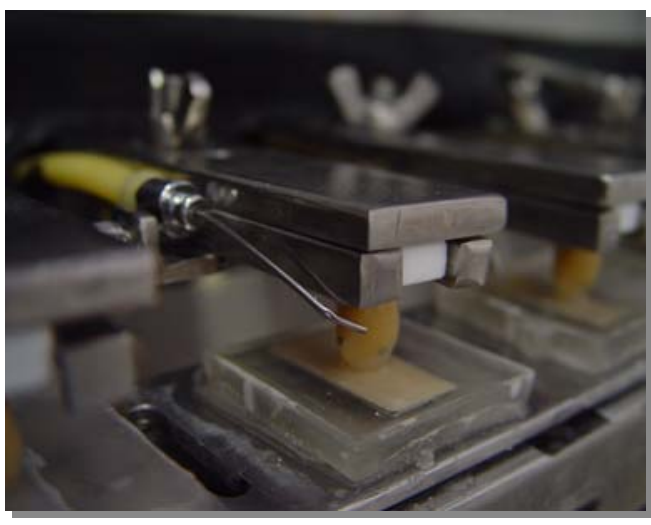

FIGURA 13 - Espécime na máquina de desgaste

A amplitude da excursão dos ciclos de desgaste foi de $20 \mathrm{~mm}$, à velocidade aproximada de 4,5 ciclos por segundo ou 270 ciclos por minuto sob 300 gramas de carga. Durante o ensaio, a máquina foi ajustada para injetar 0,4 $\mathrm{ml}$ de água deionizada por espécime em intervalos de dois minutos. Realizou-se um total de 100.000 ciclos de desgaste por grupo, durante aproximadamente oito horas. 


\subsubsection{Determinação do comprimento dentário final}

Após a realização do ensaio de desgaste, o comprimento dentário final dos espécimes foi mensurado três vezes em cada face, e os valores médios iniciais e finais calculados. A diferença entre o comprimento dentário inicial e final médio em cada face dos espécimes classificou o desgaste ocorrido. 


\section{Resultados}

\subsection{Medição da dureza}

Os ensaios de microdureza foram primordiais para a análise comparativa da dureza em diferentes níveis de profundidade na mesma marca comercial e para a comparação da perda de dureza por face nas diferentes marcas comerciais.

As medições do teste de dureza revelaram perda da dureza após a realização da ciclagem de pH em todos os espécimes avaliados (TABELA 1 e FIGURA 14). 
TABELA 1 - Média final dos valores de dureza (KHN) dos dentes artificiais antes e após a simulação do desafio ácido

\begin{tabular}{clcc}
\hline \multirow{2}{*}{ TIPO } & MARCAS & Antes & Após \\
& & & \\
& Biotone & 17,89 & 16,75 \\
Convencional & Vipident Plus & 18,62 & 17,72 \\
& Ivostar & 18,06 & 17,44 \\
& & \\
\hline \multirow{2}{*}{ Melhorado } & Biotone IPN & 19,64 & 18,80 \\
& Trilux & 17,79 & 17,17 \\
& Biolux & 18,39 & 17,66 \\
& Vivodent & 17,61 & 17,13 \\
\hline \multirow{2}{*}{ Média Geral } & & & 17,52 \\
\hline
\end{tabular}

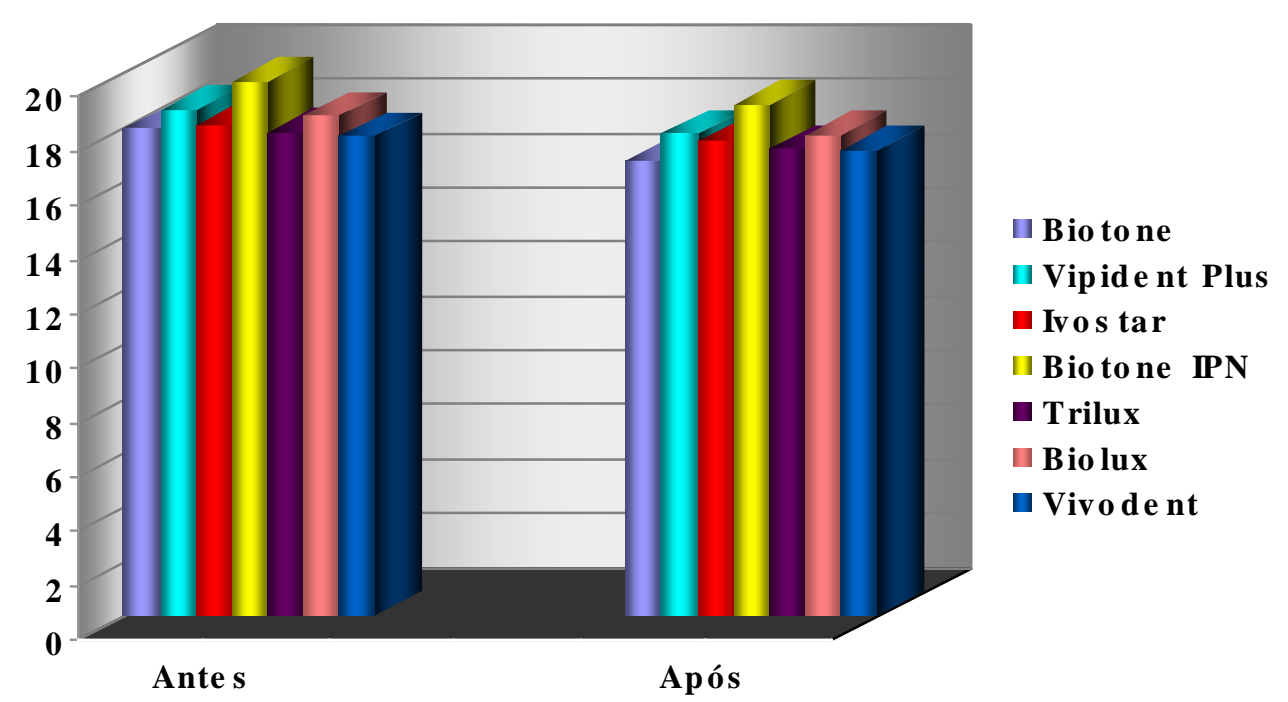

FIGURA 14 - Média final dos valores de dureza (KHN) dos dentes artificiais antes e após a simulação do desafio ácido 
A análise estatística dos valores obtidos no teste de dureza foi realizada com o programa estatístico “Statistica for Windows v.s. 5.1”. A interação das variáveis incluídas no ensaio foi verificada através da análise de variância (ANOVA) a três critérios de classificação adotando-se um valor de $\mathrm{p}<0,05$. O teste revelou a existência de diferença estatisticamente significante nos fatores marca comercial, fase (antes e após a ciclagem de pH) e face avaliados (1, 2 e 3). As variáveis marca comercial e face foram as únicas que interagiram entre si, sendo o fator fase independente (TABELA 2).

TABELA 2 - Determinação das variáveis que apresentaram interação nas medições de microdureza (KHN) através da análise de variância (ANOVA) a três critérios

\section{ANÁLISE DE VARIÂNCIA A TRÊS CRITÉRIOS}

\begin{tabular}{|c|c|c|c|c|c|c|}
\hline \multicolumn{7}{|c|}{$\begin{array}{l}\text { Interação de todas as variáveis } \\
\text { 1-MARCA 2-FASE 3-FACE }\end{array}$} \\
\hline $\begin{array}{l}\text { Fonte de } \\
\text { Variação }\end{array}$ & $\begin{array}{c}\text { GL } \\
\text { Efeito }\end{array}$ & $\begin{array}{c}\text { QM } \\
\text { Efeito }\end{array}$ & $\begin{array}{l}\text { GL } \\
\text { Erro }\end{array}$ & $\begin{array}{l}\text { QM } \\
\text { Erro }\end{array}$ & "F" & $\mathrm{p}$ \\
\hline 1 & $6^{*}$ & $26,36 *$ & $63 *$ & $0,52 *$ & $50,70^{*}$ & $0,000000 *$ \\
\hline 2 & $1 *$ & $61,10 *$ & $63^{*}$ & $0,36 *$ & $168,40 *$ & $0,000000 *$ \\
\hline 3 & $2 *$ & 1,83* & $126^{*}$ & $0,94 *$ & $19,45 *$ & $0,000000 *$ \\
\hline 12 & 6 & 0,77 & 63 & 0,36 & 2,12 & 0,062381 \\
\hline 13 & $12 *$ & $0,93 *$ & $126^{*}$ & $0,94 *$ & $9,85 *$ & $0,000000 *$ \\
\hline 23 & 2 & 0,73 & 126 & 0,44 & 1,63 & 0,199271 \\
\hline 123 & 12 & 0,71 & 126 & 0,45 & 1,59 & 0,103358 \\
\hline
\end{tabular}




\subsubsection{Comparação entre fases (antes e após a ciclagem de pH)}

O teste ANOVA revelou que houve diferença estatisticamente significante na variável fase (antes e após a ciclagem de pH). Porém, não houve interação dessa variável com os fatores marca comercial e face dentária. Assim sendo, houve diferença estatisticamente significante entre a dureza antes e após a ciclagem de $\mathrm{pH}$, independentemente da marca comercial e face avaliada. A dureza antes da realização da ciclagem de $\mathrm{pH}$ foi estatisticamente superior à dureza após, em todas faces dentárias e marcas comerciais avaliadas (TABELA 2 e FIGURA 15).

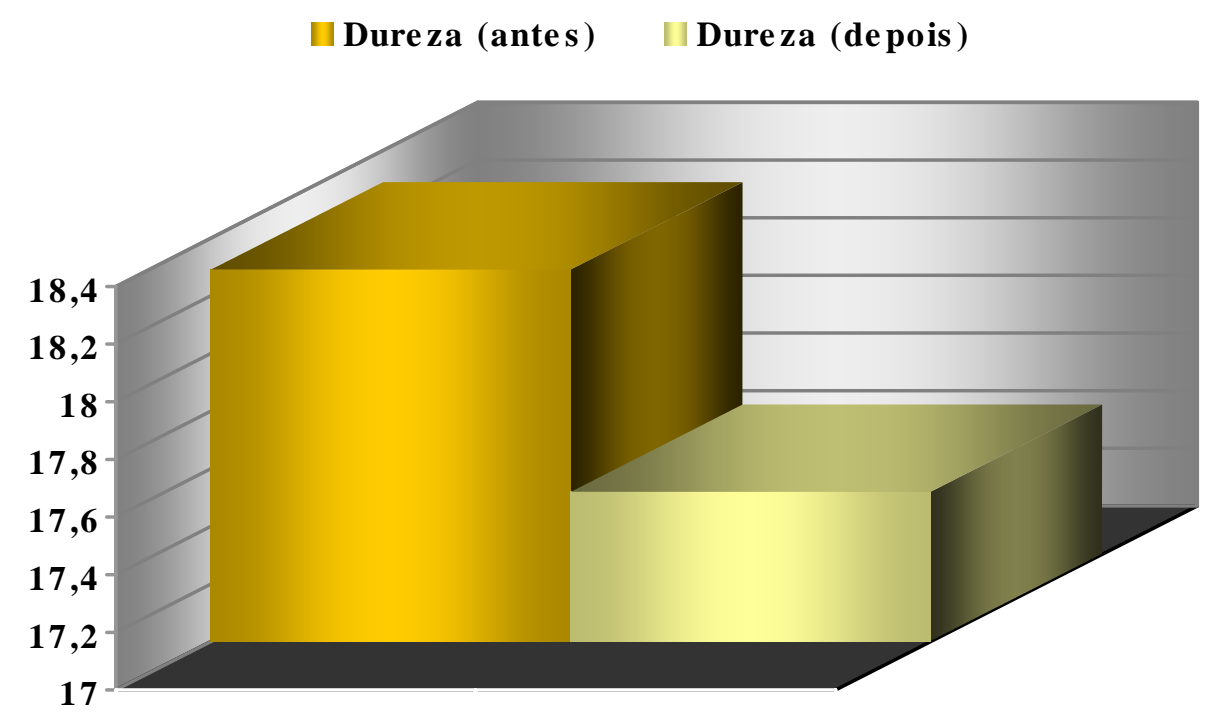

FIGURA 15 - Média final geral dos valores de dureza (KHN) dos dentes artificiais antes e após a simulação do desafio ácido $(\mathrm{p}<0,05)$ 


\subsubsection{Comparação entre faces na mesma marca comercial}

O teste de Tukey revelou valores médios de dureza estatisticamente superiores nas faces mais externas comparadas às internas em todas as marcas comerciais avaliadas, independentemente da fase de avaliação (antes ou após a ciclagem de pH), excetuando-se a marca Trilux, cuja face externa apresentou valores de dureza estatisticamente inferiores aos das faces internas (TABELA 3).

TABELA 3 - Comparação dos valores médios de microdureza Knoop (KHN) e desvio padrão nas diferentes faces (1, 2 e 3) considerando a mesma marca comercial

\begin{tabular}{clccc}
\hline \multirow{2}{*}{ Tipo } & $\begin{array}{c}\text { Marca } \\
\text { Comercial }\end{array}$ & Face 1 & Face 2 & Face 3 \\
& & & & \\
\hline \multirow{5}{*}{ Convencional } & Biotone & $17,53 \pm 0,58 \mathrm{~b}$ & $17,34 \pm 0,36 \mathrm{ab}$ & $17,12 \pm 0,62 \mathrm{a}$ \\
& Vipident & $18,25 \pm 0,61 \mathrm{~b}$ & $18,19 \pm 0,57 \mathrm{ab}$ & $18,09 \pm 0,55 \mathrm{a}$ \\
& Ivostar & $17,99 \pm 0,42 \mathrm{~b}$ & $17,75 \pm 0,34 \mathrm{a}$ & $17,53 \pm 0,40 \mathrm{a}$ \\
& & & & \\
\hline \multirow{5}{*}{ Melhorado } & & & & \\
& Biotone IPN & $19,35 \pm 0,77 \mathrm{~b}$ & $19,33 \pm 0,65 \mathrm{~b}$ & $18,98 \pm 0,43 \mathrm{a}$ \\
& Trilux & $17,05 \pm 0,67 \mathrm{~b}$ & $17,69 \pm 0,59 \mathrm{a}$ & $17,69 \pm 0,52 \mathrm{a}$ \\
& Biolux & $18,13 \pm 0,58 \mathrm{~b}$ & $18,01 \pm 0,65 \mathrm{ab}$ & $17,92 \pm 0,42 \mathrm{a}$ \\
& Vivodent & $17,67 \pm 0,59 \mathrm{c}$ & $17,31 \pm 0,48 \mathrm{~b}$ & $17,13 \pm 0,50 \mathrm{a}$ \\
& & & & \\
\hline
\end{tabular}

* Valores com as mesmas letras não possuem diferença estatisticamente significante entre si considerando a mesma marca comercial ao nível de significância de 0,05. 


\subsubsection{Comparação entre marcas comerciais na mesma face de avaliação}

O teste de Tukey revelou que a marca comercial Biotone IPN apresentou valores de dureza estatisticamente superiores às demais em todas as faces analisadas antes e após a ciclagem de $\mathrm{pH}$, sendo, portanto, a marca que apresentou o melhor comportamento perante as condições do teste. De modo inverso, considerando a face externa (antes e após a ciclagem de pH), a menor dureza ocorreu na marca Trilux. Já nas duas faces internas anteriormente à simulação do desafio ácido, a menor dureza foi observada na marca Vivodent. Por fim, após a ciclagem de $\mathrm{pH}$, a marca Biotone foi a que apresentou a maior perda de dureza em ambas as superfícies internas.

Apesar de terem ocorrido pequenas diferenças significantes entre as marcas em cada face, essas diferenças foram provavelmente insignificantes sob o ponto de vista clínico (TABELA 4).

TABELA 4 - Comparação dos valores médios de microdureza Knoop (KHN) e desvio padrão das faces e fases considerando as diferentes marcas comerciais

\begin{tabular}{|c|c|c|c|c|c|c|}
\hline \multirow{2}{*}{$\begin{array}{c}\text { Marca } \\
\text { Comercial } \\
\end{array}$} & \multicolumn{3}{|c|}{ Antes da ciclagem de $\mathrm{pH}$} & \multicolumn{3}{|c|}{ Após a ciclagem de $\mathrm{pH}$} \\
\hline & Face 1 & Face 2 & Face 3 & Face 1 & Face 2 & Face 3 \\
\hline Biotone 1 & $18,13 \pm 0,32$ a & $18,01 \pm 0,33$ abc & $17,57 \pm 0,62 \mathrm{ab}$ & $16,92 \pm 0,43 \mathrm{ab}$ & $16,67 \pm 0,36$ a & $16,66 \pm 0,44$ a \\
\hline Vipident 1 & $18,71 \pm 0,43 \mathrm{~d}$ & $18,64 \pm 0,45$ c & $18,54 \pm 0,29 \mathrm{~d}$ & $17,80 \pm 0,27 \mathrm{c}$ & $17,75 \pm 0,26 \mathrm{c}$ & $17,63 \pm 0,31$ с \\
\hline Ivostar 1 & $18,33 \pm 0,32$ acd & $18,07 \pm 0,32 \mathrm{abc}$ & $17,78 \pm 0,37 \mathrm{abc}$ & $18,33 \pm 0,32$ acd & $18,07 \pm 0,32 \mathrm{abc}$ & $17,78 \pm 0,37$ abc \\
\hline IPN & $19,85 \pm 0,53 \mathrm{e}$ & $19,66 \pm 0,75 \mathrm{~d}$ & $19,41 \pm 0,55 \mathrm{e}$ & $18,86 \pm 0,55 \mathrm{~d}$ & $19,00 \pm 0,36 \mathrm{~d}$ & $18,54 \pm 0,29 \mathrm{~d}$ \\
\hline Trilux & $17,37+0,35 \mathrm{~b}$ & $17,99+0,45 a b$ & $18,00+0,33 \mathrm{bcd}$ & $16,73+0,83$ а & $17,39+0,68$ bc & $17,38+0,61$ bc \\
\hline Biolux 1 & $18,52 \pm 0,33 \mathrm{~cd}$ & $18,33 \pm 0,35$ bc & $18,32 \pm 0,29 \mathrm{~cd}$ & $17,75 \pm 0,43$ с & $17,70 \pm 0,60 \mathrm{c}$ & $17,52 \pm 0,42$ с \\
\hline Vivodent 1 & $17,91 \pm 0,53 a b$ & $17,58 \pm 0,44 \mathrm{a}$ & $17,33 \pm 0,45$ a & $17,43 \pm 0,28$ bc & $17,04 \pm 0,36 \mathrm{ab}$ & $16,92 \pm 0,29 a b$ \\
\hline
\end{tabular}

* Valores com as mesmas letras não são estatisticamente diferentes considerando a mesma face e fase de avaliação ao nível de significância de 0,05. 


\subsection{Medição do desgaste}

As medições da altura dentária no microscópio comparador antes e após a realização do ensaio de desgaste foram essenciais para a avaliação da perda de altura gerada pelo método, classificando o desgaste ocorrido.

As mensurações revelaram uma redução da altura dentária em todos os corpos de prova testados após a realização do teste de desgaste (TABELA 5).

TABELA 5 - Valores médios (mm) das medições da altura dentária antes e após a realização do teste e o desgaste médio por marca comercial

\begin{tabular}{llccc}
\hline MARCAS & SUBSTRATO & Altura (antes) & Altura (depois) & Desgaste \\
& & & & \\
Biotone & Glazeado & 3,37 & 3,20 & 0,17 \\
Biotone & Jateado & 3,01 & 2,07 & 0,94 \\
Trilux & Glazeado & 3,47 & 3,38 & 0,09 \\
Trilux & Jateado & 2,62 & 2,42 & 0,20 \\
Vivodent & Glazeado & 3,23 & 2,82 & 0,41 \\
Vivodent & Jateado & 3,18 & 2,54 & 0,64 \\
& & & & \\
\hline
\end{tabular}


A análise estatística dos valores obtidos no teste de desgaste foi realizada com o programa estatístico “Statistica for Windows v.s. 5.1”. A interação das variáveis incluídas no ensaio foi verificada através da análise de variância (ANOVA) a três critérios de classificação adotando-se um valor de $\mathrm{p}<0,05$. O teste revelou a existência de significância estatística entre os fatores marca comercial, substrato e face. As variáveis marca comercial e substrato antagonista interagiram entre si e o fator face mostrou-se independente para a análise estatística dos dados (TABELA 6).

TABELA 6 - Determinação das variáveis que apresentaram interação no ensaio de desgaste através da análise de variância (ANOVA) a três critérios

\section{ANÁLISE DE VARIÂNCIA A TRÊS CRITÉRIOS}

\begin{tabular}{|c|c|c|c|c|c|c|}
\hline \multicolumn{7}{|c|}{$\begin{array}{l}\text { Interação de todas as variáveis } \\
\text { 1-MARCA 2-SUBSTRATO 3-FACE }\end{array}$} \\
\hline $\begin{array}{l}\text { Fonte de } \\
\text { Variação }\end{array}$ & $\begin{array}{l}\text { GL } \\
\text { Efeito }\end{array}$ & $\begin{array}{l}\text { QM } \\
\text { Efeito }\end{array}$ & $\begin{array}{l}\text { GL } \\
\text { Erro }\end{array}$ & $\begin{array}{l}\text { QM } \\
\text { Erro }\end{array}$ & “F” & $\mathrm{p}$ \\
\hline 1 & $2^{*}$ & $0,608000 *$ & $54 *$ & 0,074589* & $8,151300 *$ & $0,000806^{*}$ \\
\hline 2 & $1^{*}$ & $20,96218 *$ & $54 *$ & 0,074589* & 281,0353* & $0,000000 *$ \\
\hline 3 & $3 *$ & $0,244270 *$ & $162 *$ & $0,024831^{*}$ & $9,837500 *$ & $0,000005 *$ \\
\hline 12 & $2 *$ & $0,446960 *$ & $54 *$ & $0,074589 *$ & $5,992300 *$ & $0,004463 *$ \\
\hline 13 & 6 & 0,026140 & 162 & 0,248310 & 1,052600 & 0,393474 \\
\hline 23 & 3 & 0,101200 & 162 & 0,024831 & 0,407700 & 0,747671 \\
\hline 123 & 6 & 0,035800 & 162 & 0,024831 & 1,441700 & 0,201776 \\
\hline
\end{tabular}




\subsubsection{Comparação entre faces}

O teste de Tukey revelou que o desgaste na face mesial foi estatisticamente superior ao desgaste apresentado nas outras faces em todas as marcas comerciais e substratos analisados $(\mathrm{p}<0,05)$ - TABELA 7.

TABELA 7 - Comparação dos valores médios de desgaste (mm) por face mensurada através do teste de Tukey

\begin{tabular}{l|c}
\hline Face & Média \\
\hline Palatina & 0,39 \\
Distal & 0,43 \\
Vestibular & 0,44 \\
Mesial & 0,54 \\
& \\
\hline
\end{tabular}

* Valores conectados com uma linha vertical não apresentam diferença estatística entre si ao nível de significância de 0,05. 


\subsubsection{Comparação entre marcas comerciais nos diferentes substratos}

O teste de Tukey revelou que não houve diferença estatisticamente significante entre as três marcas comerciais (Biotone, Trilux e Vivodent) atritadas contra a porcelana glazeada.

Porém, considerando-se o substrato jateado, houve diferença estatisticamente significante entre as marcas avaliadas, sendo que a marca Biotone apresentou desgaste significantemente maior que as demais (Trilux e Vivodent), as quais não diferiram estatisticamente entre si.

O desgaste das marcas Biotone, Trilux e Vivodent no substrato jateado foi estatisticamente superior às mesmas marcas atritadas contra o substrato glazeado (TABELA 8 e FIGURA 16). 
TABELA 8 - Comparação dos valores médios de desgaste $(\mathrm{mm})$ entre marcas comerciais através do teste de Tukey

\begin{tabular}{llr}
\hline $\begin{array}{c}\text { Marca } \\
\text { Comercial }\end{array}$ & Porcelana & Média (mm) \\
\hline Trilux & Glazeada & 0,14 \\
Vivodent & Glazeada & 0,16 \\
Biotone & Glazeada & 0,17 \\
Vivodent & Jateada & 0,64 \\
Trilux & Jateada & 0,66 \\
Biotone & Jateada & 0,93 \\
& & \\
\hline
\end{tabular}

* Valores conectados com uma linha vertical não apresentam diferença estatística entre si ao nível de significância de 0,05.

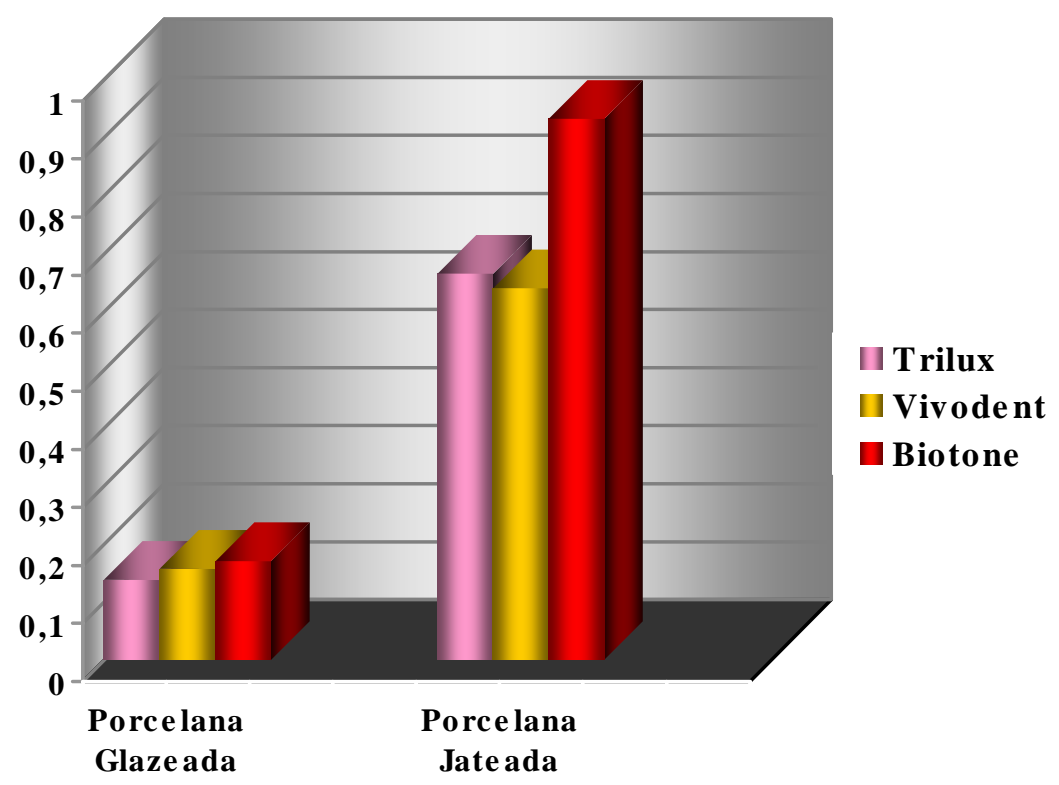

FIGURA 16 - Média dos valores de desgaste (mm) dos dentes artificiais atritados contra a porcelana glazeada e jateada 


\section{Discussão}

A maioria dos estudos sobre as propriedades mecânicas dos dentes artificiais foi realizada através da avaliação do índice de desgaste BEALL ${ }^{11}$, 1943, BODDICKER ${ }^{12}$, 1947, CORNELL et al. ${ }^{17}, 1957$, MYERSON $^{37}, 1957$, FRANKS $^{24}, 1962$, THOMSON $^{55}$, 1962, OHASHI et al. $^{44}, 1973$, HARRISON; HUGGETT ${ }^{26}, 1975$, HARRISON $^{25}, 1976$, APPELBAUM $^{10}$, 1984, KHAN; MORRIS; von FRAUNHOFER ${ }^{32}$, 1984, KHAN; MORRIS; von FRAUNHOFER ${ }^{31}$, 1985, OGLE; ORTMAN ${ }^{43}$, 1985, OGLE; DAVID; ORTMAN $^{41}$, 1985, Von FRAUNHOFER; RAZAVI; KHAN ${ }^{57}$, 1988, EFKELDT; OILO $^{21}$, 1989, ADAMS; JOOSTE; THOMAS 5 , 1989, ADAMS; JOOSTE; THOMAS ${ }^{4}$, 1991, WRINKLER; MONASKY; KWOK ${ }^{61}$, 1992, SATOH, et al. ${ }^{50}$, 1992, SATOH, et al. $^{51}$, 1992, SATOH, et al. $^{49}, 1993$, DOUGLAS; DELONG; PINTADO ${ }^{20}$, 1993, LINDQUIST; OGLE; DAVIS ${ }^{34}$, 1995, ADAMS et al. ${ }^{3}$, 1996, HIRANO et al. ${ }^{27}$, 1998, e JOOSTE; OGLE; DAVIS ${ }^{28}$, 1998, havendo uma menor preocupação com a dureza superficial KAWANO et al. ${ }^{30}$, 2002, NOGUEIRA, et al. ${ }^{38}$, 2002, e PAVARINA et al. ${ }^{46}$, 2003, ou com a associação de ambas as propriedades mecânicas dos materiais dentários que compõem esses produtos WHITMAN et al. ${ }^{60}$, 1987, JOOSTE; GEERTS; GROBLER $^{29}$, 1996, ABE et al. ${ }^{1}, 1997$, ABE et al., 2001² , e SUZUKI ${ }^{54}$, 2004. Embora as propriedades mecânicas de resistência ao desgaste e dureza superficial sejam entidades distintas, pode ou não existir associação entre ambas, o que faz com que esses termos sejam muitas vezes utilizados erroneamente, gerando extrapolações que nem sempre correspondem à realidade.

Existe uma crença propagada pelos fabricantes e arraigada nos profissionais da Odontologia, enaltecendo a maior dureza apresentada por determinados modelos de 
dente. Entretanto, o termo dureza é invariavelmente confundido com o padrão de desgaste dos materiais, e utilizado freqüentemente para expressá-lo. A extensa quantidade de pesquisas sobre o desgaste de dentes artificiais contrastada com a pífia atenção ao estudo da dureza superficial, só confirmam a intempérie sobre o assunto.

O termo dureza é difícil de ser definido e, de fato, não existe uma definição específica para tal. Em mineralogia, a dureza relativa de um material baseia-se na sua capacidade de resistir ao arranhamento (riscamento). Em metalurgia, e na maioria das outras áreas, o conceito mais aceito relaciona-se à resistência do material à penetração (PHILLIPS $^{47}$, 1993, e ANUSAVICE $\left.{ }^{7}, 1998\right)$. Portanto, a dureza de um material é determinada a partir da realização de testes padronizados que promovam a penetração de uma ponta no interior do material, em aparelhos chamados durômetros. A utilização dessa nomenclatura para expressar a impressão clínica de maior resistência ao desgaste ao uso de fresas odontológicas, caracteriza, desta forma, um erro semântico.

Embora alguns estudos de dureza superficial tenham utilizado a unidade de medida Vickers para a análise de dentes artificiais KAWANO et al. ${ }^{30}$, 2002, e PAVARINA et al. ${ }^{46}$, 2003, a mensuração mais adequada para o estudo de materiais poliméricos é a dureza Knoop (WHITMAN et al. ${ }^{60}$, 1987, ABE et al. ${ }^{1}$, 1997, ANUSAVICE $^{7}, 1998$, ABE et al. ${ }^{2}, 2001$, e SUZUKI ${ }^{54}$, 2004).

Os testes de microdureza superficial Vickers e Knoop utilizam cargas inferiores a um Kgf e permitem a mensuração da dureza em pequenas regiões de objetos muito finos, sendo a primeira indicada para o estudo de materiais friáveis e a segunda para os materiais poliméricos. A indicação da dureza Knoop para os polímeros deve-se ao fato de que a diagonal do losango mensurada para a determinação do valor de dureza (diagonal de maior comprimento) permanece livre de alterações dimensionais, ao passo 
que a recuperação elástica e as alterações dimensionais ocorrem ao longo da diagonal mais curta. Portanto, o valor de dureza Knoop virtualmente independe da ductibilidade do material testado devido à ação de rasgamento promovida ao longo da diagonal maior do losango, diferentemente do que ocorre com a impressão quadrangular da dureza Vickers, na qual há deformação elástica de forma similar em ambas as diagonais do quadrado impresso na superfície do material. Além disso, o uso da dureza Vickers é mais adequado para materiais friáveis e não poliméricos (CRAIG; O’BRIEN; POWERS $^{19}$, 1988, PHILLIPS ${ }^{47}, 1993$, O’BRIEN $^{39}, 1997$, e ANUSAVICE $\left.{ }^{7}, 1998\right)$.

Os estudos de dureza de dentes artificiais usualmente basearam-se na mensuração dos valores após o acondicionamento dos espécimes em água destilada WHITMAN et al. ${ }^{60}$, 1987, ABE et al. ${ }^{1}, 1997$, KAWANO et al. ${ }^{30}$, 2002, e PAVARINA et al. $^{46}$, 2003, álcool WHITMAN et al. ${ }^{60}$, 1987, ou soluções desinfetantes PAVARINA et al. $^{46}$, 2003. Entretanto, essas soluções utilizadas não simulam a dinâmica do meio bucal, caracterizada por constantes alterações do nível de $\mathrm{pH}$ do biofilme microbiano CARVALHO; CURY ${ }^{14}, 1999$.

Segundo $\operatorname{CATE}^{15}$, 1990, a ciclagem de pH em boca ocorre devido à ação do biofilme microbiano sobre os carboidratos fermentáveis consumidos (rápido declínio do pH) e devido à ação tampão da saliva (gradual elevação do $\mathrm{pH}$ ), caracterizando o fenômeno conhecido como des-remineralização. Ao longo do dia, isso resulta numa série de depressões de pH de 30 minutos de duração, intercaladas com períodos de “repouso”. Similarmente, uma dieta alimentar rica em alimentos ácidos também poderia levar à flutuação do pH oral e criar um processo semelhante ao desenvolvido pela microbiota cariogênica, sendo novamente tamponado pela ação natural da saliva. 
A apreciação desses fatores levou ao desenvolvimento de modelos nos quais os ciclos de $\mathrm{pH}$ ocorridos intra-oralmente fossem simulados em desenhos experimentais in vitro. Isso foi conseguido através da imersão dos espécimes diariamente, por períodos limitados, em soluções alternadas de desmineralização e remineralização. O modelo laboratorial de ciclagem de pH viabilizou a mimetização das depressões e elevações do nível de $\mathrm{pH}$ ocorridas no meio bucal e permitiu a análise in vitro da influência do processo des-remineralização sobre os materiais dentários CATE ${ }^{15}, 1990$.

Embora a dinâmica de $\mathrm{pH}$ proposta por esse protocolo seja vantajosa, ainda existem numerosas diferenças entre os modelos laboratoriais de ciclagem e as condições in vivo (como a ausência de enzimas, proteínas salivares, película e biofilme microbiano), que limitam, em parte, a réplica das condições do ambiente oral CATE, $1990^{15}$

É sabido que nos indivíduos dentados, a dinâmica do $\mathrm{pH}$ intra-oral pode levar ao desenvolvimento de processos cariosos ou erosivos, pois a solubilidade do mineral fosfato de cálcio é pH-dependente CATE ${ }^{15}$, 1990. Entretanto, a influência da flutuação do $\mathrm{pH}$ sobre a dureza dos dentes artificiais de resina acrílica utilizados em próteses dentárias não havia sido investigada até então.

O protocolo de ciclagem de $\mathrm{pH}$ desenvolvido inicialmente por $\mathrm{CATE}^{15}, 1990$, para o estudo in vitro da liberação do flúor de materiais dentários, e modificado posteriormente por CARVALHO; CURY ${ }^{14}$, 1999, mostrou-se pertinente para a avaliação da dinâmica de pH sobre a dureza dos dentes artificiais neste estudo. Desta forma, após a obtenção dos valores de dureza Knoop nas três faces dos espécimes antes e após o desafio ácido, as médias foram agrupadas na TABELA 1 e FIGURA 14, e a análise estatística revelou valores de dureza iniciais estatisticamente superiores aos 
obtidos posteriormente, independentemente da marca comercial e face em análise (TABELAS 1 e 2 e FIGURAS 14 e 15).

Os valores de dureza Knoop variaram de 18,28 (antes da ciclagem de $\mathrm{pH}$ ) a 17,52 (após a ciclagem de pH), com uma redução média de aproximadamente 5\%. Algumas semelhanças foram encontradas com o trabalho de PAVARINA et al. ${ }^{46}, 2003$, no qual houve um decréscimo contínuo na dureza relacionado com o tempo de armazenagem dos espécimes em água (p>0,05) após 30, 60 e 120 dias de imersão, apesar de não ter ocorrido diferença estatisticamente significante entre as marcas comerciais e soluções desinfetantes testadas $(p>0,05)$. NOGUEIRA et al. ${ }^{38}$, 2002, ao analisarem a dureza dos dentes artificiais de resina acrílica submetidos a diferentes agentes de limpeza em função do tempo, também encontraram uma redução significativa da dureza superficial Vickers dos dentes artificiais imediatamente $(32,93)$ e seis meses após o acondicionamento $(20,02)$. Inversamente, o teste in vitro realizado por WHITMAN et al. ${ }^{60}$, 1987, indicou que os materiais armazenados em água (resina acrílica convencional, resina IPN e Isosit) apresentaram valores de dureza inicial e final praticamente iguais, ou seja, não houve o amolecimento do material. Porém, quando armazenados em etanol ocorreu redução dos valores, indicando perda de dureza.

Acredita-se que os dentes artificiais apresentem uma camada superficial mais dura em relação ao núcleo dentário $\mathrm{ADAMS}^{3}$, 1996, de forma semelhante ao que ocorre na dentição natural (na qual o esmalte possui uma dureza maior que a dentina). Entretanto, os fabricantes de dentes artificiais não confirmaram essa hipótese e alegaram a utilização do mesmo material para a fabricação de todo o corpo dentário, ainda que sejam realizadas várias prensagens durante a acrilização dos dentes em busca de resultados estéticos mais satisfatórios. A única empresa que confirmou a utilização de 
materiais diferenciados no exterior dos dentes foi a Ivoclar Vivadent, considerando o modelo de dente posterior ${ }^{\mathrm{SR}}$ Orthosit ${ }^{\circledR}$ PE, cuja camada externa seria constituída de polimetil-metacrilato com ligação cruzada e a porção interna de material compósito (Isosit $\left.{ }^{\circledR}\right)$.

Apesar disso, a análise estatística dos valores médios finais de dureza (TABELA 3), revelou que a face mais externa apresentou resultados estatisticamente superiores aos das faces mais internas em todas as marcas comerciais, com exceção da Trilux. Porém, embora tenha ocorrido diferença do ponto de vista estatístico, os valores de dureza entre as faces foram extremamente semelhantes entre si e, muito provavelmente, sem qualquer significado clínico relevante. Isso explicaria a informação colhida com os fabricantes referente à fabricação de toda a estrutura dentária com o mesmo material, e igualaria clinicamente as diferentes camadas dentárias em termos de composição química e dureza superficial.

Os dentes de resina acrílica convencional oscilaram de 17,89 a 18,62 (antes) até 16,75 a 17,72 (após), e os dentes de resina acrílica melhorada entre 17,61 a 19,64 (antes) até 17,13 a 18,8 (após) - TABELA 1. ABE et al. ${ }^{1}$, 1997, e ABE et al. ${ }^{2}, 2001$, encontraram valores de dureza Knoop mais elevados para os dentes de alta resistência (em torno de 37), embora a dureza encontrada no dente de resina acrílica convencional tenha sido ligeiramente inferior $(16,6)$ em comparação aos presentes achados. Considerando os dentes acrílicos, os valores de dureza Knoop encontrados por SUZUKI $^{54}$, 2004, estiveram de acordo com os resultados do presente estudo, girando em torno de 18,6 para os dentes de resina acrílica convencional e de 18,9 a 21,6 para a resina acrílica melhorada. Ao se fazer uma análise individual (TABELA 1), os dentes de resina acrílica da marca comercial Biotone apresentaram perda de dureza de 6,38\% do 
valor inicial, seguido pelo Vipi Dent Plus (4,84\%), Biotone IPN (4,28\%), Biolux (3,97\%), Trilux (3,49\%), Ivostar (3,44\%) e Vivodent (2,73\%). Entretanto, apesar de todas as marcas comerciais terem apresentado perda de dureza, a diferença estatística entre os valores de dureza Knoop nas diferentes faces e fases analisadas foi muito pequena dada à grande similaridade entre os valores médios individuais (TABELA 4). Isso impediu a classificação quantitativa dos dentes convencionais e melhorados quanto à dureza superficial e a padronização dos resultados de acordo com a região ou o ambiente de avaliação. A única exceção foi a marca Biotone IPN (composta de resina acrílica modificada com rede polimérica interpenetrada), que se destacou por apresentar valores de dureza estatisticamente superiores às demais em todas as faces antes e após a ciclagem de $\mathrm{pH}$, sendo, portanto, a única marca que apresentou um comportamento padronizado perante as condições do teste.

Considerando os dentes que apresentaram os menores valores de dureza, mais uma vez os resultados variaram em função da face ou da fase. Na face externa (antes e após a ciclagem de pH), o menor valor foi encontrado na marca Trilux. Já nas duas faces internas anteriormente à simulação do desafio ácido, a menor dureza foi observada na marca Vivodent. Após a ciclagem de $\mathrm{pH}$, a marca Biotone foi a que apresentou a maior perda de dureza em ambas as superfícies internas. (TABELA 4) Apesar disso, vale lembrar que as diferenças estatísticas foram estreitas, considerando todas as marcas em estudo.

Observou-se que as marcas Trilux e Biotone foram as mais susceptíveis à ciclagem ácida considerando a face externa dos dentes, ao passo que as marcas Biotone e Vivodent foram as mais vulneráveis no interior dos dentes. (TABELA 4) Poder-se-ia afirmar que essas marcas comerciais teriam indicação limitada em indivíduos com dieta 
rica em alimentos ácidos, que apresentem hábitos alimentares de alta susceptibilidade à cárie ou que estejam expostos a doenças que levem ao refluxo do conteúdo gástrico ao ambiente intra-oral (doença do refluxo gástrico-esofágico ou distúrbios da alimentação, como bulimia e anorexia nervosa). Porém, a estreita proximidade dos valores de dureza dos dentes avaliados, limitaram a advocacia das marcas que seriam mais resistentes ao meio ácido.

A estreita diferença no quesito dureza entre as marcas comerciais avaliadas foi um achado surpresa, pois era suposto que as formulações melhoradas apresentassem dureza maior que as fórmulas convencionais. Esse fator sugeriu que, apesar de os dentes apresentarem valores de dureza semelhantes entre si, poderiam apresentar resistência ao desgaste favorável às marcas melhoradas, sendo o primeiro indício de independência dessas propriedades mecânicas dos materiais dentários, revelado pelo trabalho em questão.

Diversas metodologias têm sido propostas para avaliar a evolução do padrão de desgaste in vivo BEALL ${ }^{11}$, 1943, FRANKS ${ }^{24}$, 1962, HARRISON; HUGGETT ${ }^{26}$, 1975, HARRISON $^{25}$, 1976, OGLE; ORTMAN ${ }^{43}$, 1985, OGLE; DAVID; ORTMAN ${ }^{41}, 1985$, ADAMS; JOOSTE; THOMAS 5 , 1989, ADAMS; JOOSTE; THOMAS ${ }^{4}$, 1991, LINDQUIST; OGLE; DAVIS ${ }^{34}$, 1995, ADAMS, et al. ${ }^{3}, 1996$, JOOSTE; GEERTS; ADAMS $^{28}, 1997$ e OGLE; DAVIS ${ }^{42}$, 1998, ou in vitro BODDICKER ${ }^{12}, 1947$, CORNELL $^{17}, 1957$, MYERSON $^{37}, 1957$, THOMSON $^{55}, 1962$, OHASHI et al. ${ }^{44}, 1973$, KHAN; MORRIS; von FRAUNHOFER ${ }^{32}$, 1984, KHAN; MORRIS; von FRAUNHOFER $^{31}$, 1985, WHITMAN, et al. ${ }^{60}, 1987$, von FRAUNHOFER; RAZAVI; $\mathrm{KHAN}^{57}$, 1988, SATOH et al. $^{50}$, 1992, SATOH et al. ${ }^{51}$, 1992, WRINKLER; MONASKY; KWOK ${ }^{61}$, 1992, SATOH, et al. ${ }^{49}$, 1993, DOUGLAS; DELONG; 
PINTADO $^{20}$, 1993, ABE, et al. ${ }^{1}, 1997$, HIRANO $^{27}$, et al., 1998, ABE, et al. ${ }^{2}$, 2001, e SUZUKI ${ }^{54}$, 2004, dos dentes artificiais poliméricos, desde o estudo pioneiro de BEALL $^{11}, 1943$, até recentemente no trabalho de SUZUKI ${ }^{54}, 2004$, refletindo a falta de padronização dos modelos clínicos e desenhos laboratoriais utilizados e dificultando a comparação dos resultados disponíveis. Portanto, o estabelecimento de uma máquina padrão e reproduzível para o desenvolvimento de uma linha de pesquisa laboratorial pertinente mostrou-se imperioso WHITMAN, et al. ${ }^{60}$, 1987, pois o único meio plausível para a comparação dos resultados consistia na listagem dos materiais testados em cada estudo, sendo a comparação numérica inviável em função das discrepâncias dos achados obtidos de acordo com o método de avaliação LINDQUIST; OGLE; DAVIS ${ }^{34}, 1995$.

Isto posto, o presente estudo avaliou ambas as propriedades mecânicas dos dentes artificiais (dureza superficial e resistência ao desgaste) e elaborou uma metodologia padronizada e reproduzível para o teste de desgaste. Para tal, foi utilizada uma máquina de escovação universalmente conhecida, sendo necessária apenas uma pequena adaptação para a fixação dos espécimes nesse dispositivo. O movimento de vai-vém realizado pela máquina mostrou-se adequado para a atrição dos espécimes sob uma carga de $0,3 \mathrm{~kg}$, semelhantemente à força média requerida para a mastigação realizada pelos usuários de próteses totais, variável entre 0,3 e 1,8kg YURKSTAS; CURBY $^{58}$, 1953. Para mimetizar as condições bucais, foram utilizadas placas antagonistas revestidas de porcelana feldspática com dois diferentes tratamentos de superfície (glazeamento e jateamento). A cerâmica glazeada correspondeu à superfície que deve ser idealmente encontrada na prática clínica, ao passo que o substrato cerâmico jateado simulou a rugosidade superficial apresentada por restaurações cerâmicas (inlays, onlays, coroas isoladas ou próteses fixas) após a realização de ajuste 
oclusal em boca (com brocas diamantadas e pontas de acabamento) posteriormente à cimentação da prótese, acarretando na eliminação da camada externa de glaze. Vale lembrar que essa circunstância é extremamente comum, uma vez que muitos clínicos enviam a infra-estrutura metálica para a aplicação da porcelana no laboratório e pedem para que a peça retorne glazeada, ou seja, pronta para a cimentação. Dessa maneira, como invariavelmente há a necessidade de realização do ajuste oclusal em boca após a queima da porcelana, uma superfície rugosa permanece sobre a restauração ou eventualmente sobre o esmalte dentário desgastado e, embora possa ser polida com brocas e pontas de acabamento, jamais voltará a apresentar a mesma lisura da superfície glazeada. Por fim, todo o processo de desgaste foi realizado à temperatura de $37+/-2$ ${ }^{\circ} \mathrm{C}$, sob lubrificação à água.

Para a avaliação da associação entre a dureza e o índice de desgaste dos dentes artificiais, foram selecionadas três marcas comerciais com diferentes características: Biotone (resina acrílica convencional), Trilux (resina IPN) e Vivodent (resina com dupla ligação cruzada), consideradas semelhantes entre si quanto à dureza superficial (TABELA 4).

A resistência ao desgaste dos dentes artificiais, revelada no substrato glazeado, mostrou que os três tipos de dentes não apresentaram diferença estatística entre si com relação à resistência ao desgaste (apesar das diferenças numéricas), provavelmente devido ao pequeno desgaste ocorrido contra esse substrato (TABELA 8). De maneira semelhante, no trabalho de WINKLER; MONASKY; KWOK ${ }^{61}$, 1992, todas as marcas comerciais exibiram desgastes insignificantes, embora as marcas convencionais tenham apresentado resistência ao desgaste maior que as formulações melhoradas. Esses resultados foram confirmados clinicamente por JOOSTE; GEERTS; ADAMS ${ }^{28}$, 1997, 
que avaliaram a resistência ao desgaste de seis dentes artificiais de resina acrílica disponíveis comercialmente e não encontraram diferença estatisticamente significante entre o desgaste dos dentes testados. Porém, considerando-se o substrato jateado no presente estudo, houve diferença estatisticamente significante entre o desgaste das marcas avaliadas, sendo que o dente de resina convencional (Biotone) apresentou desgaste significantemente superior ao das formulações com propriedades melhoradas (Trilux e Vivodent) - (TABELA 8). Esses resultados estiveram de acordo com os achados pioneiros de CORNELL et al. ${ }^{17}$, 1957, e posteriormente de WHITMAN et al. ${ }^{60}$, 1987, e SATOH et al. ${ }^{50}$, 1992, que encontraram maior resistência abrasiva dos dentes artificiais de alta resistência quando comparados aos dentes convencionais. Modelos clínicos OGLE; DAVID; ORTMAN ${ }^{41}$, 1985, também encontraram diferença estatisticamente significante entre o dente convencional e modificado, pois após 36 meses, os dentes de resina IPN apresentaram resistência ao desgaste significantemente maior que os de resina acrílica convencional. Um estudo divergente realizado por WINKLER; MONASKY; KWOK ${ }^{61}$, 1992, concluiu que as formulações novas com resistência ao desgaste supostamente aumentada não apresentaram superioridade em relação aos dentes de resina convencional, embora as diferenças tenham sido pequenas e provavelmente clinicamente insignificantes.

Considerando-se apenas os dentes melhorados (Trilux e Vivodent), o presente estudo revelou que não houve diferença estatisticamente significante no desgaste de ambas as formulações atritadas contra o substrato glazeado ou jateado (TABELA 8). Um modelo in vivo elaborado por LINDQUIST; OGLE; DAVIS ${ }^{34}$, 1995, e conduzido para comparar o desgaste de três dentes de resina modificada, também revelou a inexistência de diferença estatística entre o desgaste apresentado pelos dentes artificiais 
nos intervalos de seis a 12 meses e após 12 meses de avaliação clínica. Esses achados foram confirmados aos 36 meses de avaliação OGLE; DAVIS ${ }^{42}$, 1998, e já haviam sido observados por JOOSTE; GEERTS; ADAMS ${ }^{28}$, 1997. Porém, uma avaliação de vários dentes melhorados DOUGLAS; DELONG; PINTADO ${ }^{20}$, 1993, constatou diferença entre os materiais, sendo que os dentes de resina IPN e material de sobrevida prolongada apresentaram significantemente menos desgaste que os outros três materiais também aperfeiçoados. Refutando os presentes achados, testes in vitro von FRAUNHOFER; RAZAVI; KAHN ${ }^{57}$, 1988, também revelaram que os dentes de resina modificada de alta resistência apresentaram resistência ao desgaste 40 a 50 \% superior a outro dente de resina melhorada.

A inter-relação de ambas as propriedades deve ser realizada considerando-se os resultados dicotômicos obtidos no teste de desgaste. Embora a dureza não possa ser considerada um indicador confiável para o desgaste dentário, os resultados obtidos no substrato glazeado sugeriram que houve associação entre a dureza e o padrão de desgaste dos materiais, uma vez que as três marcas apresentaram dureza e padrão de desgaste semelhantes entre si. ABE et al. ${ }^{1}$, 1997, e ABE et al. ${ }^{2}$, 2001, também encontraram uma associação entre os valores de dureza Knoop dos materiais testados com a sua respectiva resistência ao desgaste (à exceção dos dentes compósitos), indicando que a dureza poderia ser um possível parâmetro para prever o desgaste de materiais contra o esmalte dentário. Porém, considerando o substrato jateado no presente estudo, não houve associação entre as propriedades, pois embora os valores de dureza tenham sido similares nos três dentes avaliados, a marca Biotone apresentou desgaste significantemente maior que as formulações melhoradas (Trilux e Vivodent) e essas por sua vez não diferiram entre si em ambos os ensaios. Corroborando com os 
achados obtidos no substrato jateado, um modelo in vitro similar WHITMAN et al. ${ }^{60}$, 1987, também não encontrou associação entre o índice de desgaste e a dureza do material, pois embora não tenha havido diferença estatisticamente significante no índice de desgaste em água e etanol das amostras de IPN e Isosit, ocorreu o seu amolecimento na presença do etanol. Ao correlacionarem a dureza e a resistência ao desgaste clínico de seis marcas de dentes artificiais de polimetil-metacrilato opostos a dentes de porcelana, JOOSTE; GEERTS; GROBLER ${ }^{29}$, 1996, também não encontraram associação, uma vez que os dentes mais duros não apresentaram a maior resistência ao desgaste.

O marketing propagado pelos fabricantes odontológicos considerando a maior resistência ao desgaste dos materiais melhorados (vulgarmente denominados "dentes alemães ou importados”) em relação à resina acrílica convencional foi confirmado neste estudo, pois houve desgaste significantemente menor das formulações melhoradas quando comparado à formulação convencional no substrato jateado. Esse achado e a uniformidade dos resultados do teste de dureza sugeriram que os dentes de resina acrílica modificada seriam, na verdade, mais resistentes ao desgaste (e não mais duros) que os dentes acrílicos com ligações cruzadas convencionais. Isso explicaria o uso freqüentemente incorreto do termo dureza, invariavelmente confundido por muitos autores e profissionais da odontologia com a propriedade mecânica de resistência ao desgaste. Desta forma, parece que a dureza por si só não seria determinante para a promoção do desgaste dentário, e que outros fatores influenciariam o processo de abrasão simultaneamente.

Foi sugerido por MYERSON ${ }^{37}, 1957$ e THOMSON $^{55}$, 1965, que o desgaste dentário "in vivo" pode ser causado pelo contato entre os dentes lubrificados pela saliva 
ou pelo contato entre os dentes e o alimento. Contudo, o período de contato dentário efetivo ocorrido durante a mastigação relatado por SHEPPARD; MARKUS ${ }^{53}$, 1962, foi ínfimo, não excedendo 11,7 minutos ao dia, o que sugeriu que esse fator não seria tão relevante para o fenômeno de desgaste na dentição humana. Semelhantemente, MÜLLER ${ }^{36}$, 1966, afirmou que o contato entre os dentes superiores e inferiores durou apenas 130 a 140 milisegundos em cada ciclo mastigatório, totalizando $20 \%$ da sua duração total. Entretanto, apesar da curta duração e baixa freqüência, observou-se que os contatos dentários ocorreram tanto durante o ciclo mastigatório BREWER; HUDSON $^{13}$, 1961, como durante o ato de deglutição SCHÄRER; STALLARD ${ }^{52}$, 1965, não havendo contato, porém, no período de repouso. Os achados de FRANKS ${ }^{24}, 1962$, corroboraram com a hipótese de o desgaste dentário não ser causado pelo contato entre dentes, pois não houve correlação significante entre o desgaste dos dentes artificiais e o período diário de uso das próteses em seu estudo. THOMSON ${ }^{55}, 1965$, por sua vez, estabeleceu uma associação entre a atrição dos dentes de acrílico e a ação da dieta em indivíduos que apresentavam hábito alimentar rico em saladas e alimentos duros, sugerindo a importância dos alimentos no processo de perda de estrutura dentária.

Assim sendo, parece que o desgaste dentário oriundo do contato entre dentes estaria associado provavelmente à realização de hábitos para-funcionais, dada à pequena magnitude dos contatos dentários fisiológicos. Contudo, esses contatos ao longo da vida útil da prótese seriam capazes de gerar desgaste nos dentes artificiais, principalmente se associado a constantes desafios ácidos.

Dessa forma, outros fatores parecem influenciar o fenômeno da atrição dentária, como o padrão de mastigação FRANKS $^{24}$, 1962, e KHAN; MORRIS; von FRAUNHOFER ${ }^{32}, 1984$, a freqüência de mastigação PHILLIPS ${ }^{47}$, 1993, a força de 
mordida FRANKS ${ }^{24}$, 1962, KHAN; MORRIS; von FRAUNHOFER ${ }^{32}$, 1984, e PHILLIPS $^{47}$, 1993, a abrasividade da dieta FRANKS ${ }^{24}$, 1962, THOMSON ${ }^{55}, 1965$, KHAN; MORRIS; von FRAUNHOFER ${ }^{32}$, 1984, e PHILLIPS ${ }^{47}, 1993$, hábitos parafuncionais THOMSON ${ }^{55}$, 1965, e HARRISON ${ }^{25}$, 1975, a ação de agentes de limpeza das próteses $\mathrm{THOMSON}^{55}, 1965$, as propriedades físicas dos materiais (incluindo a dureza e a aspereza superficial) MYERSON ${ }^{37}$, 1957, HARRISON; HUGGET ${ }^{26}$, 1975, APPELBAUM $^{10}$, 1984, PHILLIPS ${ }^{47}$, 1993, e ABE et al. ${ }^{1}, 1997$, a composição dos líquidos, as variações de temperatura PHILLIPS ${ }^{47}$, 1993, e a atmosfera empoeirada HARRISON; HUGGET ${ }^{26}, 1975$.

Em 1986, OLTHOFF et al. ${ }^{45}$ relataram uma força máxima de mordida de $51 \mathrm{Kg}$ para a dentição natural e 30\% inferior em usuários de próteses totais. Além disso, os autores sugeriram que as forças usadas durante a mastigação variam de um alimento para outro, mas são substancialmente inferiores à força máxima de mordida. Corroborando com valores de força máxima de mordida mais baixos em usuários de próteses, WATT et al. ${ }^{59}$, 1958, relataram força média de 21,7 kg em dentes naturais, de 11,2 kg em selas de próteses removíveis dento-suportadas e de 7,4 kg em próteses de extremo livre. YURKSTAS; CURBY ${ }^{58}$, 1953, também encontraram valores baixos para a força máxima registrada em usuários de próteses $(12 \mathrm{~kg})$, sendo a força média requerida para a mastigação variável entre 0,3 e 1,8 kg. Apesar disso, foi sugerido que a força de mordida teria influência sobre o fenômeno de desgaste dentário intra-oral nos indivíduos edentados (FRANKS ${ }^{24}$, 1962, KHAN; MORRIS; von FRAUNHOFER ${ }^{32}$, 1984, e PHILLIPS ${ }^{47}$, 1993).

Os resultados do estudo de THOMSON ${ }^{55}$, 1965, demonstraram a influência dos hábitos alimentares e para-funcionais e a ação de agentes abrasivos de limpeza sobre a 
atrição dos dentes. Nesse estudo, houve correlação entre a presença de superfícies rugosas e contornos arredondados nos dentes das próteses e o padrão de dieta rico em saladas e alimentos duros. Em contraste com esse padrão, o desgaste ocorrido em pessoas que habitualmente rangeram ou apertaram os dentes produziu facetas planas polidas e ângulos afiados nas superfícies oclusais e esteve associado clinicamente com traumas aos tecidos de suporte, sugerindo sobrecarga oclusal. Por fim, houve associação do uso excessivo de agentes de limpeza abrasivos com a perda de detalhes anatômicos das superfícies oclusais das dentaduras.

Em um trabalho pioneiro para avaliar o desgaste de dentes artificiais com diferentes combinações de materiais, BODDICKER ${ }^{12}$, 1947, mostrou que os dentes acrílicos desgastaram mais rapidamente que os de porcelana ou de ouro em todos os testes, enquanto MYERSON ${ }^{37}$, 1957, concluiu que o acrílico oposto à porcelana desgastou menos que a porcelana oposta à porcelana ou o acrílico oposto ao acrílico. $\mathrm{O}$ trabalho de HARRISON; HUGGET ${ }^{26}$, 1975, revelou que a combinação porcelana / resina acrílica produziu desgaste significante da resina acrílica e que a combinação resina acrílica / resina acrílica foi mais resistente ao desgaste que a combinação porcelana / resina acrílica. Quando se analisou o desgaste de próteses totais presas a um articulador OHASHI et al. ${ }^{44}$, 1973, observou-se que a combinação de resina em ambos os arcos foi a mais susceptível ao desgaste. Um estudo in vitro ABE et al. ${ }^{1}$, 1997, avaliou o desgaste de dentes artificiais posteriores de resina composta de alta resistência opostos a oito materiais dentários e os resultados indicaram que o menor desgaste foi observada nos espécimes opostos à liga de ouro-prata-paládio, enquanto o maior ocorreu contra a porcelana. No presente estudo, as características superficiais do substrato jateado provocaram desgaste dos espécimes significantemente maior em 
comparação ao produzido pelo substrato glazeado (TABELA 8). Todos esses achados indicaram a importância da combinação de materiais no fenômeno de abrasão.

Assim sendo, o mecanismo de desgaste no meio oral é extremamente complexo e envolve na verdade a interação de numerosos fatores simultaneamente THOMSON $^{55}$, 1965, e KHAN; MORRIS; von FRAUNHOFER ${ }^{32}$, 1984, sendo a dureza apenas um desses fatores PHILLIPS ${ }^{47}$, 1993. Desse modo, os achados de dureza parecem ser apenas indicadores da habilidade do material em resistir ao desgaste e não deveriam ser extrapolados diretamente para inferir o padrão de desgaste do mesmo. O uso uma propriedade mecânica isolada para representar um fenômeno extremamente amplo, como o é o processo de desgaste dos materiais dentários, caracteriza não apenas um erro semântico, mas também a simplificação extrema de um complexo mecanismo. 


\section{Conclusões}

As seguintes conclusões foram obtidas a partir deste trabalho:

1) O desafio ácido reduziu de maneira estatisticamente significativa a dureza superficial dos dentes artificiais.

2) A dureza da superfície externa dos dentes artificiais foi estatisticamente superior à interna, com exceção da marca Trilux.

3) A diferença estatística dos resultados de dureza entre as diferentes marcas comerciais foi considerada provavelmente irrelevante do ponto de vista clínico.

4) Não houve diferença estatisticamente significativa na resistência ao desgaste entre as marcas Biotone, Trilux e Vivodent atritadas contra a porcelana glazeada. Porém, a marca Biotone sofreu desgaste significantemente maior que as demais contra a porcelana jateada.

5) Não houve associação entre dureza e resistência ao desgaste para as marcas avaliadas no substrato jateado. 


\section{ANEXOS}

ANEXO 1 - Valores médios de microdureza superficial (KHN) e desvio padrão das marcas comerciais em cada nível de profundidade (faces 1, 2 e 3) antes e após o processo de simulação do desafio cariogênico.

\begin{tabular}{|c|c|c|c|c|c|c|c|}
\hline \multicolumn{4}{|c|}{ Microdureza Inicial } & \multicolumn{4}{|c|}{ Microdureza Final } \\
\hline MARCAS & $\begin{array}{l}\text { Face } 1 \\
\text { Início }\end{array}$ & $\begin{array}{c}\text { Face } 2 \\
\text { Início }\end{array}$ & $\begin{array}{l}\text { Face } 3 \\
\text { Início }\end{array}$ & $\begin{array}{c}\text { Face } 1 \\
\text { Fim }\end{array}$ & $\begin{array}{c}\text { Face } 2 \\
\text { Fim }\end{array}$ & $\begin{array}{c}\text { Face } 3 \\
\text { Fim }\end{array}$ & $\mathrm{n}$ \\
\hline Biotone & 18,13 & 18,01 & 17,57 & 16,92 & 16,67 & 16,66 & 10 \\
\hline Vipident Plus & 18,70 & 18,63 & 18,54 & 17,80 & 17,75 & 17,62 & 10 \\
\hline Ivostar & 18,33 & 18,07 & 17,78 & 17,65 & 17,43 & 17,28 & 10 \\
\hline Biotone IPN & 19,85 & 19,66 & 19,41 & 18,86 & 19,00 & 18,54 & 10 \\
\hline Trilux & 17,37 & 17,99 & 18,00 & 16,73 & 17,39 & 17,38 & 10 \\
\hline Biolux & 18,52 & 18,33 & 18,31 & 17,75 & 17,70 & 17,52 & 10 \\
\hline Vivodent & 17,91 & 17,58 & 17,33 & 17,43 & 17,04 & 16,92 & 10 \\
\hline $\begin{array}{c}\text { Todas as } \\
\text { marcas }\end{array}$ & 18,40 & 18,33 & 18,14 & 17,59 & 17,57 & 17,42 & 70 \\
\hline \multicolumn{8}{|c|}{ Desvio Padrão } \\
\hline MARCAS & $\begin{array}{c}\text { Face } 1 \\
\text { Início }\end{array}$ & $\begin{array}{c}\text { Face } 2 \\
\text { Início }\end{array}$ & $\begin{array}{c}\text { Face } 3 \\
\text { Início }\end{array}$ & $\begin{array}{c}\text { Face } 1 \\
\text { Fim }\end{array}$ & $\begin{array}{c}\text { Face } 2 \\
\text { Fim }\end{array}$ & $\begin{array}{c}\text { Face } 3 \\
\text { Fim }\end{array}$ & $\mathrm{n}$ \\
\hline Biotone & 0,32 & 0,33 & 0,62 & 0,43 & 0,36 & 0,44 & 10 \\
\hline Vipident Plus & 0,43 & 0,45 & 0,29 & 0,27 & 0,26 & 0,31 & 10 \\
\hline Ivostar & 0,32 & 0,32 & 0,37 & 0,37 & 0,34 & 0,28 & 10 \\
\hline Biotone IPN & 0,53 & 0,75 & 0,55 & 0,55 & 0,36 & 0,29 & 10 \\
\hline Trilux & 0,35 & 0,45 & 0,33 & 0,83 & 0,68 & 0,60 & 10 \\
\hline Biolux & 0,33 & 0,35 & 0,29 & 0,44 & 0,60 & 0,41 & 10 \\
\hline Vivodent & 0,53 & 0,44 & 0,45 & 0,28 & 0,36 & 0,29 & 10 \\
\hline $\begin{array}{c}\text { Todas as } \\
\text { marcas }\end{array}$ & 0,82 & 0,77 & 0,77 & 0,79 & 0,80 & 0,67 & 70 \\
\hline
\end{tabular}


ANEXO 2 - Valores médios da altura dos dentes $(\mu \mathrm{m})$ nas faces vestibular, palatina, mesial e distal antes e após a realização do ensaio, desgaste médio e desvio padrão.

\begin{tabular}{|c|c|c|c|c|c|c|c|c|}
\hline MARCAS & $\begin{array}{c}\mathrm{V} \\
\text { Antes } \\
\text { Média }\end{array}$ & $\begin{array}{c}\mathrm{V} \\
\text { Antes } \\
\mathrm{dP}\end{array}$ & $\begin{array}{c}\mathrm{P} \\
\text { Antes } \\
\text { Média }\end{array}$ & $\begin{array}{c}\mathrm{P} \\
\text { Antes } \\
\mathrm{dP}\end{array}$ & $\begin{array}{c}\text { M } \\
\text { Antes } \\
\text { Média }\end{array}$ & $\begin{array}{c}\mathrm{M} \\
\text { Antes } \\
\mathrm{dP}\end{array}$ & $\begin{array}{c}\text { D } \\
\text { Antes } \\
\text { Média }\end{array}$ & $\begin{array}{c}\mathrm{D} \\
\text { Antes } \\
\mathrm{dP}\end{array}$ \\
\hline Biotone Glazeado & 2,94 & 0,23 & 2,52 & 0,12 & 3,93 & 0,55 & 4,08 & 0,33 \\
\hline Biotone Jateado & 2,42 & 0,38 & 2,03 & 0,24 & 3,14 & 0,40 & 4,41 & 0,83 \\
\hline Trilux Glazeado & 2,96 & 0,19 & 2,41 & 0,21 & 4,64 & 0,48 & 3,88 & 0,54 \\
\hline Trilux Jateado & 2,57 & 0,41 & 1,80 & 0,24 & 3,92 & 0,56 & 2,91 & 0,38 \\
\hline Vivodent Glazeado & 2,89 & 0,24 & 2,36 & 0,23 & 3,67 & 0,59 & 3,99 & 0,50 \\
\hline Vivodent Jateado & 2,74 & 0,36 & 2,35 & 0,17 & 4,21 & 0,79 & 3,41 & 0,69 \\
\hline MARCAS & $\begin{array}{c}\mathrm{V} \\
\text { Após } \\
\text { Média }\end{array}$ & $\begin{array}{c}\mathrm{V} \\
\text { Após } \\
\mathrm{dP}\end{array}$ & $\begin{array}{c}\text { P } \\
\text { Após } \\
\text { Média }\end{array}$ & $\begin{array}{c}\mathrm{P} \\
\text { Após } \\
\mathrm{dP}\end{array}$ & $\begin{array}{c}\text { M } \\
\text { Após } \\
\text { Média }\end{array}$ & $\begin{array}{c}\text { M } \\
\text { Após } \\
\text { dP }\end{array}$ & $\begin{array}{c}\text { D } \\
\text { Após } \\
\text { Média }\end{array}$ & $\begin{array}{c}\mathrm{D} \\
\text { Após } \\
\mathrm{dP}\end{array}$ \\
\hline Biotone Glazeado & 2,72 & 0,24 & 2,49 & 0,60 & 3,65 & 0,59 & 3,94 & 0,31 \\
\hline Biotone Jateado & 1,54 & 0,42 & 1,16 & 0,19 & 2,11 & 0,40 & 3,47 & 0,79 \\
\hline Trilux Glazeado & 2,84 & 0,20 & 2,27 & 0,21 & 4,45 & 0,50 & 3,78 & 0,54 \\
\hline Trilux Jateado & 1,84 & 0,23 & 1,22 & 0,22 & 3,17 & 0,55 & 2,32 & 0,49 \\
\hline Vivodent Glazeado & 2,79 & 0,24 & 2,22 & 0,23 & 3,45 & 0,61 & 3,82 & 0,49 \\
\hline Vivodent Jateado & 2,15 & 0,39 & 1,75 & 0,26 & 3,43 & 0,63 & 2,83 & 0,73 \\
\hline MARCAS & $\begin{array}{c}\mathrm{V} \\
\text { Desg. } \\
\text { Média }\end{array}$ & $\begin{array}{c}\mathrm{V} \\
\text { Desg. } \\
\text { dP }\end{array}$ & $\begin{array}{c}\mathrm{P} \\
\text { Desg. } \\
\text { Média }\end{array}$ & $\begin{array}{c}\mathrm{P} \\
\text { Desg. } \\
\mathrm{dP}\end{array}$ & $\begin{array}{c}\text { M } \\
\text { Desg. } \\
\text { Média }\end{array}$ & $\begin{array}{c}\text { M } \\
\text { Desg. } \\
\text { dP }\end{array}$ & $\begin{array}{c}\text { D } \\
\text { Desg. } \\
\text { Média }\end{array}$ & $\begin{array}{c}\text { D } \\
\text { Desg. } \\
\text { dP }\end{array}$ \\
\hline Biotone Glazeado & 0,22 & 0,11 & 0,28 & 0,57 & 0,28 & 0,15 & 0,15 & 0,89 \\
\hline Biotone Jateado & 0,88 & 0,15 & 0,87 & 0,15 & 1,03 & 0,17 & 0,94 & 0,18 \\
\hline Trilux Glazeado & 0,11 & 0,45 & 0,14 & 0,38 & 0,18 & 0,78 & 0,11 & 0,05 \\
\hline Trilux Jateado & 0,74 & 0,34 & 0,58 & 0,16 & 0,75 & 0,13 & 0,59 & 0,21 \\
\hline Vivodent Glazeado & 0,11 & 0,82 & 0,14 & 0,77 & 0,22 & 0,11 & 0,16 & 0,12 \\
\hline Vivodent Jateado & 0,60 & 0,17 & 0,60 & 0,17 & 0,78 & 0,29 & 0,59 & 0,17 \\
\hline
\end{tabular}




\section{Referências Bibliográficas}

1) ABE, Y. et al. An in vitro study of high-strength resin posterior denture tooth wear. Int J Prosthodont, v.10, n.1, p.28-34, 1997.

2) ABE, Y. et al. An in vitro wear study of posterior denture tooth materials on human enamel. J Oral Rehabil, v.28, p.407-12, 2001.

3) ADAMS, L.P. et al. Biostereometric quantification of clinical denture tooth wear. J Oral Rehabil, v.23, p.667-74, 1996.

4) ADAMS, L.P.; JOOSTE, C.H.; THOMAS, C.J. Accuracy of a replication technique for biostereometric evaluation of clinical tooth wear. J Am Dent Assoc, v.46, p.363-4, 1991.

5) ADAMS, L.P.; JOOSTE, C.H.; THOMAS, C.J. An indirect in vivo method for quantification of wear of denture teeth. Dent Mat, v.5, p.31-4, Jan. 1989.

6) ANUSAVICE, K.J. Propriedades físicas dos materiais dentários. In:

Phillips: materiais dentários. 10.ed. Rio de Janeiro, Guanabara Koogan, c1998. Cap.3, p.18-9.

7) ANUSAVICE, K.J. Propriedades mecânicas dos materiais dentários. In: Phillips: materiais dentários. 10.ed. Rio de Janeiro, Guanabara Koogan, c1998. Cap.4, p.40-1.

8) ANUSAVICE, K.J. Química das Resinas Sintéticas. In: Phillips: materiais dentários. 10.ed. Rio de Janeiro, Guanabara Koogan, c1998. Cap.10, p.125-39.

9) ANUSAVICE, K.J. Resina para base de dentadura. Considerações técnicas e técnicas de processamento. In: Phillips: materiais dentários. 10.ed. Rio de Janeiro, Guanabara Koogan, c1998. Cap.11, p.159. 
10) APPELBAUM, M. Theories of posterior tooth selection: porcelain versus acrylic. Dent Clin N Amer, v.28, n.2, p.299-306, Apr. 1984.

11) BEALL, J.R. Wear of acrylic resin teeth. J Am Dent Assoc, v.30, n.1, p.252-6, 1943.

12) BODDICKER, V.S. Abrasion tests for artificial teeth. J Am Dent Assoc, v.35, n.1, p.793-7, 1947.

13) BREWER, A.A.; HUDSON, D.C. Application of minituarized electronic devices to the study of tooth contact in complete dentures. J Prosthet Dent, v.11, p.62, 1961.

14) CARVALHO, A.S.; CURY, J.A. Fluoride release from some dental materials in different solutions. Oper Dent, v.24, n.1, p.17-9, Jan/Feb. 1999.

15) CATE, J.M.T. In vitro studies on the effects of fluoride on de- and remineralization. J Dent Res, v.69, n.1, p.614-9, Jan/Mar. 1990.

16) COMBE, E.C.; BURKE, F.J.T.; DOUGLAS, W.H. Polymers. In:

Dental biomaterials. Boston, kluwer, c1999. Cap.11, p.81-92.

17) CORNELL, J.A. et al. A method of comparing the wear resistance of various materials used for artificial teeth. J Am Dent Assoc, v.54, p.608-14, 1957.

18) CRAIG, R.G.; O’BRIEN, W.J.; POWERS, J.M. Plásticos em prótese. In: Materiais dentários: propriedades e manipulação. 3.ed. Rio de Janeiro, Guanabara Koogan, c1988. Cap.13, p.169-84.

19) CRAIG, R.G.; O’BRIEN, W.J.; POWERS, J.M. Propriedades dos materiais. In: . Materiais dentários: propriedades e manipulação. 3.ed. Rio de Janeiro, Guanabara Koogan, c1988. Cap.2, p.17. 
20) DOUGLAS, W.H.; DELONG, R.; PINTADO, M.R. Wear rates of artificial denture teeth opposed by natural dentition. J Clin Dent, v.4, n.2, p.43-7, 1993.

21) EFKELDT, A.; OILO, G. Wear mechanisms of resin and porcelain denture teeth. Acta Odontol Scand, v.47, p.391-9, 1989.

22) FEATHERSTONE, J.D. et al. Enhancement of remineralization in vitro and in vivo. In: Leach S.A. Factors relating to demineralization and remineralization of the teeth. Oxford, IRL, 1986. p.23-34.

23) FERRACANE, J.L. Polymers for Prosthetics. In: Materials in dentistry: principles and applications. Baltimore, Lippincott, c2001. Cap.12, p.255-80.

24) FRANKS, A.S.T. A clinical appraisal of acrylic tooth wear. Dent Pract, v.12, n.5, p.149-53, 1962.

25) HARRISON, A. Clinical results of the measurement of occlusal wear of complete dentures. J Prosthet Dent, v.35, n.5, p.504-11, May 1976.

26) HARRISON, A.; HUGGETT, R. Measuring the rate of wear of artificial teeth in complete dentures. J Prosthet Dent, v.33, n.6, p.615-9, June 1975.

27) HIRANO, S. et al. In vitro wear of resin denture teeth. J Prosthet Dent, v.79, n.2, p.152-5, 1998.

28) JOOSTE, C.; GEERTS, G.; ADAMS, L. Comparison of the clinical abrasion resistance of six commercially available denture teeth. J Prosthet Dent, v.77, n.1, p.23-7, 1997. 
29) JOOSTE, C.H.; GEERTS, G.A.; GROBLER, S.R. Correlation between hardness and clinical abrasion resistance of denture teeth. J Dent Res, v.75, n.5, p.1308, 1996.

30) KAWANO, F. et al. Shock absorbability and hardness of commercially available denture teeth. Int J Prosthodont, v.15, n.3, p.243-7, 2002.

31) KHAN, Z.; MORRIS, J.C.; von FRAUNHOFER, J.A. Wear of anatomic acrylic resin denture teeth. J Prosthet Dent, v.53, n.4, p.550-1, Apr. 1985.

32) KHAN, Z.; MORRIS, J.C.; von FRAUNHOFER, J.A. Wear of nonanatomic (monoplane) acrylic resin denture teeth. J Prosthet Dent, v.52, n.2, p.172-4, Aug. 1984.

33) KORAN, A.; CRAIG, R.G.; TILLITSON, E.W. Coefficient of friction of prosthetic tooth material. J Prosthet Dent, v.27, n.3, p.269-74, Mar. 1972.

34) LINDQUIST, T.J.; OGLE, R.E.; DAVIS, E.L. Twelve-month results of a clinical wear study of three artificial tooth materials. J Prosthet Dent, v.74, n.2, p.156-61, Aug. 1995.

35) McDOWELL, G.C., et al. In vivo wear. Part I: The Michigan computer-graphic measuring system. J Prosthet Dent, v.60, n.1, p.112-20, July 1988.

36) MÜLLER, E. The chewing apparatus. Acta physiol Scand, v. 69, p. 280, 1966. Supplement

37) MYERSON, R.L. The use of porcelain and plastic teeth in opposing complete dentures. J Prosthet Dent, v.7, n.5, p.625-33, Sept. 1957.

38) NOGUEIRA, C.M. et al. Effects of denture cleanser agentes upon artificial teeth hardness. J Dent Res, v.81, (sp.issue): p B179, Dec. 2002. 
39) O’BRIEN, W.J. Physical properties. In: Dental materials and their seletion. 2.ed. Chicago, Quintessence, c1997. Cap.2, p.18-9.

40) O'BRIEN, W.J. Polymers and polymerization: denture base polymers. In: . Dental materials and their seletion. 2.ed. Chicago, Quintessence, c1997. Cap.6, p.79-95.

41) OGLE, R.E.; DAVID, L.J.; ORTMAN, H.R. Clinical wear study of a new tooth material: Part II. J Prosthet Dent, v.54, n.1, p.67-75, July 1985.

42) OGLE, R.E.; DAVIS, E.L. Clinical wear study of three commercially available artificial tooth materials: Thirty-six month results. J Prosthet Dent, v.79, n.2, p.145-51, 1998.

43) OGLE, R.E.; ORTMAN, L.F. Measuring wear of artificial teeth with stereophotography: Part I. J Prosthet Dent, v.53, n.6, p.807-12, June 1985.

44) OHASHI, M. et al. A pilot manufacture of biting abrasion testing machine for the full denture and its test result. J Nihon Univ Sch Dent, v.15, n.3, p.96101, Sept. 1973.

45) OLTHOFF, L.W.; VAN DER BILT, A.; DE BOER, A.; BOSMAN, F. Comparison of force-deformation characteristics of artificial and several natural foods for chewing experiments. J Text Stud, v.17, n.3, p.275-89, 1986.

46) PAVARINA, A.C. et al. The effect of disinfectant solutions on the hardness of acrylic resin denture teeth. J Oral Rehabil, v.30, p.749-52, 2003.

47) PHILLIPS, R.W. Propriedades físicas dos materiais dentários. Reologia. Cor. Propriedades térmicas. In: . Skinner: materiais dentários. 9.ed. Rio de Janeiro, Guanabara Koogan, c1993. Cap.3, p.23-4. 
48) PHILLIPS, R.W. Química das resinas sintéticas. In: Skinner: materiais dentários. 9.ed. Rio de Janeiro, Guanabara Koogan, c1993. Cap.10, p.91-02.

49) SATOH, S. et al. Study on high-strength plastic teeth. Tooth discoloration. J Nihon Univ Sch Dent, v.35, p.192-9, 1993.

50) SATOH, S. et al. Wear of denture teeth by use of metal plates. Part 2: Abrasive wear of posterior teeth. J Nihon Univ Sch Dent, v.34, p.16-27, 1992.

51) SATOH, S. et al. Wear of denture teeth by use of metal plates. Part 3: Abrasive wear of posterior teeth and wear of opposing metal plates. J Nihon Univ Sch Dent, v.34, p.249-64, 1992.

52) SCHÄRER, P.; STALLARD, R.E. The use of multiple radio transmitters in studies of tooth contact patterns. Periodont, v.3, p.5, 1965.

53) SHEPPARD, I.M.; MARKUS, N. Total time of tooth contacts during mastication. J Prosthet Dent, v.12, p.460, 1962.

54) SUZUKI, S. In vitro wear of nano-composite denture teeth. J Prosthodont, v.13, n.4, p.238-43, Dec. 2004.

55) THOMSON, J.C. Attrition of acrylic teeth. Dent Pract, v.15, n.7, p.233-6, Mar. 1965.

56) TURSSI, C.P. Micromorfologia superficial de materiais estéticos submetidos

a diferentes processos de degradação. Piracicaba, 2001. Dissertação (Mestrado) - Faculdade de Odontologia de Piracicaba, Universidade Estadual de Campinas.

57) von FRAUNHOFER, J.A.; RAZAVI, B.S.R.; KHAN, Z. Wear characteristics of high-strength denture teeth. J Prosthet Dent, v.59, n.2, p.173-5, 1988. 
58) YURKSTAS, A.; CURBY, W. A. Force analysis of prosthetic applicances during function. J Prosthet Dent, v.3, n.1, p.82-7, Jan. 1953.

59) WATT, D.M. et al. A preliminary investigation of the support of partial dentures and its relationship to vertical loads. Dent Prac Dent Rec, v.9, p.1, 1958.

60) WHITMAN, D.J. et al. In vitro wear rates of three types of commercial denture tooth materials. J Prosthet Dent, v.57, n.2, p.243-6, Feb. 1987.

61) WRINKLER, S.; MONASKY, G.E.; KWOK, J. Laboratory wear investigation of resin posterior denture teeth. J Prosthet Dent, v.67, n.6, p.812-14, 1992. 


\section{ABSTRACT \\ An in vitro analysis of Knoop hardness and wear resistance of acrylic \\ resin denture teeth}

Knoop hardness of three conventional acrylic teeth denture brands (Trubyte Biotone, Vipi Dent Plus and Ivostar) and four improved acrylic teeth denture brands (Biotone IPN, Trilux, Biolux and Vivodent) was evaluated. The specimens $(n=10)$ were cut, flattened and measured in three different levels into the teeth before and after being submitted to acid challenge. The correlation between hardness and wear rate was obtained through three different teeth denture brands: Biotone (conventional acrylic resin), Trilux (IPN acrylic resin) e Vivodent (acrylic resin with double cross-linked). The wear apparatus was designed to produce sliding contact of all the specimens $(n=10)$ against glazed and sandblasting porcelain during 100.000 times at 4,5 cycles per minute, with a $4 \mathrm{~mm}$ sliding distance per stroke in the buccolingual direction under a $300 \mathrm{~g}$ load of circulated water. Wear values were determined in millimeters using measuring microscope. Hardness and wear mean values were analyzed by three-way ANOVA and Tukey test. Knoop hardness data (KHN) ranged from 17,89 to 18,62 (before) and 16,75 to 17,72 (after) for conventional acrylic teeth denture and from 17,61 to 19,64 (before) and 17,13 to 18,8 (after) for improved acrylic teeth denture. The acid challenge significantly decreased the hardness to both acrylic teeth denture brands $(p<0,05)$. The outer surface was significantly harder than the internal one for all brands tested, exception for Trilux brand $(\mathrm{p}<0,05)$. There was not uniformity in hardness between all the brands at different surfaces and ambient, preventing the election of the hardest $(\mathrm{p}<0,05)$. The wear on glazed porcelain was $0,14 \mathrm{~mm}$ for Trilux, 0,16 mm for Vivodent and $0,17 \mathrm{~mm}$ for Biotone. On sandblasting porcelain, the wear was $0,64 \mathrm{~mm}$ for 
Vivodent, 0,66 mm for Trilux and 0,93 $\mathrm{mm}$ for Biotone. Wear rates for Biotone brand were significantly higher than the others at sandblasting porcelain $(p<0,05)$. The significant difference on hardness results between all brands tested was considered probably clinically insignificant $(\mathrm{p}<0,05)$. There was not correlation between hardness and wear for all brands tested on sandblasting porcelain. 